\title{
LIETUVIŲ STATYBOS (INŽINERIJOS) BATALIONAI 1943-1944 M.
}

\author{
Dr. Rimantas Zizas
}

Nacių Vokietijos okupacijos metais Lietuvoje buvo suformuoti ir vokiečių policijos bei kariuomenès (vermachto) žinioje veikẻ vadinamieji savisaugos (apsaugos) batalionai, statybos (inžinerijos) batalionai, Lietuvos vietinė rinktiné, Tẻvynès apsaugos rinktinè, kiti mažesni kariniai daliniai. Iš visų svarbiausių vokiškos kilmès lietuviškų karinių formuočių iki šiol mažiausiai tyrinėta vermachto sudètyje veikusių lietuvių statybos (inžinerijos, vokiškai - Litauische Bauabteilung) batalionų istorija. Šie batalionai buvo formuojami ir ị vokiečių Šiaurès fronto užnugari siunčiami 1943 m. gegužès-rugpjūčio mėnesi po nepavykusio bandymo suformuoti Lietuvoje SS legioną.

Statybos batalionų istorijai nušviesti iki šiol nėra skirta nė vieno didesnès apimties mokslinio straipsnio. Jų istorija trumpai apžvelgiama "Lietuvių enciklopedijos"1 straipsnyje, kai kurie organizavimo ir veiklos klausimai epizodiškai nušviesti istorikų K. Rukšèno ${ }^{2}$, A. Bubnio ${ }^{3}$, P. Stankero $^{4}$, Henrio L. Gaidžio ${ }^{5}$ monografijose, tačiau iki šiol istoriografijoje nebuvo bandymų išsamiau ir konceptualiau pažvelgti i statybos batalionų istorijos klausimus. Negausioje lietuvių statybos (inžinerijos) batalionų istoriografijoje nemažai ịvairaus pobūdžio klaidų, netikslumų, prieštaringų duomenų. Antai Henry L. Gaidis tvirtina, kad plk. K. Pranckonio vadovaujamas lietuvių statybos dalinys veikė prie Stalingrado, P. Stankeras teigia, kad 1943 m. Lietuvoje buvo suformuoti 6 statybos (inžinerijos) batalionai. Tyrinèti įvairūs archyviniai ir kiti šaltiniai nepatvirtina šių teiginių. Labai ivvairuoja skaičiai nurodant, kiek statybos (inžinerijos) batalionuose tarnavo Lietuvos vyrų: Henry L. Gaidžio duomenimis - apie 4 tūkst., P. Stankeras rašo, kad vermachto inžineriniuose daliniuose tarnavo 1,4 tūkst. vyrų ir t.t. ${ }^{6}$ Lietuvių statybos batalionų istorijos klausimai menkai atsispindi ir

\footnotetext{
${ }^{1}$ Statybos batalionai. Lietuviu enciklopedija, t. 28, p. 468.

${ }^{2}$ Rukšènas K. I vergovę. Vilnius, 1966, p. 58-73.

${ }^{3}$ Bubnys A. Vokiečiu okupuota Lietuva (1941-1944). Vilnius, 1998, p. 386-392.

${ }^{4}$ Stankeras P. Lietuviu policija 1941-1944 metais. Vilnius, 1998, p. 189-191.

${ }^{5}$ Gaidis Henry L. A history of the Lithuanian military forces in world war II, 1939-1945. Chicago, Illinois, 199?, p.167-169.
}

${ }^{6}$ Henry L. Gaidis ,min. veik.p. 167; Stankeras P. min. veik., p. 187. 
memuarinejje literatūroje: iš Lietuvoje paskelbtų atsiminimų kaip vertingą istorijos šaltini šių batalionų istorijai pažinti galima paminèti tik 2ojo lietuvių statybos bataliono, vẻliau Lietuvos vietinès rinktinès kario Prano Nagio atsiminimus ${ }^{7}$.

Lietuvių statybos batalionų istorijos tyrinėjimus labai sunkina negausūs pirminiai autentiški archyvų šaltiniai. Lietuvos archyvuose nėra atskirų statybos batalionų fondų ar mažesnių archyvinès medžiagos saugojimo vienetų (bylų), dokumentų apie jų veiklą rytuose, vokiečiu Šiaurès armijų grupuotes užnugaryje. Tokių dokumentų turètų būti užsienio, visų pirma Vokietijos, Rusijos ir kitų šalių, archyvuose, tačiau jie Lietuvos istorikams dar sunkiai pasiekiami. Lietuvos archyvuose saugomi dokumentai, atspindintys statybos batalionų istoriją, labai fragmentiški, juose daug spragų, iš jų sunku susidaryti istoriškai tikslų, argumentuotą ir nuoseklų šių batalionų istorijos vaizdą. Iš pirminių autentiškų šaltinių pažymètini Lietuvos centriniame valstybès archyve (toliau - LCVA) ir Lietuvos visuomenès organizacijų archyve (toliau - LVOA) saugomi vokiečiu okupacinio režimo Lietuvoje ir lietuviškosios "savivaldos" įvairių institucijų dokumentai apie karinès mobilizacijos eigą ir statybos batalionų organizavimą 1943 m. (straipsnyje plačiai panaudoti LCVA Tauragés aps. viršininko fonde saugomi archyviniai šaltiniai).

Nemažai įvairios medžiagos yra vokiečių okupacijos metais oficialiai leistoje spaudoje, tačiau joje, saugant karines paslaptis, mažai skelbta konkrečių faktų ir duomenų, kurtas pagražintas, idealizuotas statybos batalionų veiklos vaizdas. Lietuvių antinacinio pogrindžio šaltiniuose ir spaudoje atvirkščiai, siekiant atgrasinti Lietuvos jaunimą nuo tarnybos batalionuose, jų veikla buvo nušviečiama kritiškai, nepalankiai, negatyviomis, niūriomis spalvomis, taigi taip pat ne visada objektyviai. Statybos batalionų istorijai nušviesti yra svarbūs sovietiniai šaltiniai.Tai labai ịvairaus pobūdžio dokumentai. Iš jų visų pirma pažymètini pas sovietų partizanus pafrontèje, Leningrado srityje, ir kitur perbėgusių ar patekusių jiems į nelaisvę statybos batalionų karių (1944 m. pavasarị, išvadavus Leningrado sritị, jie buvo pasiųsti į Raudonosios armijos 16-osios lietuviškosios šaulių divizijos 2-aji atsargos batalioną Balachnoje (Gorkio sr.) parodymai ir jų apklausų me-

${ }^{7}$ Nagys Pr. Gyvenimo vingiuose: Lietuva, Vokietija, Australija, Lietuva: Atsiminimai, Vilnius, 1998, p. 59-77; Tas pat: Martinionis A. Lietuviai vermachte 1941-1945. Vilnius, 1999, p. 66-106; Nagys Pr. Pasitraukiam nuo fronto. Kardas: Istorinis tautinès minties žurnalas. 1996, Nr. 5-6, p. 15-16. 
džiaga. Vokiečiu armijoje tarnavusieji lietuviai kariai buvo apklausinėjami ir tardomi, siekiant gauti informacijos apie lietuviškas formuotes vokiečių kariuomenejje ir karo metų ìvykius Lietuvoje. Tokią informaciją rinko LKP CK ir Maskvoje ịsikūręs Lietuvos sovietinio partizaninio judèjimo štabas (LPJŠ), jame veikè 2-asis žvalgybos ir informacijos skyrius, vadovaujamas SSRS valstybės saugumo papulkininkio B. Baranausko. Iš visų buvusių lietuvių statybos batalionų karių parodymų vertingiausi yra 5-ojo lietuvių statybos bataliono būrio vado ltn. Jono Borevičiaus parodymai. Iš įvairių šaltinių matyti, kad jis buvo prieštaringa ir nenuosekli asmenybė. J. Borevičius (g. 1914m.) 1936 m. baigé Lietuvos karo mokyklą, buvo vienuoliktos laidos kariūnas aspirantas. Vèliau mokesi Kauno universiteto farmacijos fakultete. Prasidejus Vokietijos-SSRS karui, buvo Tautinio darbo apsaugos bataliono Alytaus kuopos "smogiamojo būrio" vadas. Eidamas šias pareigas (i jas ięejo ir buvusių kompartijos ir sovietų valdžios aktyvistų persekiojimas bei žydų šaudymas), parodè daug "iniciatyvos ir veiklumo", vèliau dirbo Alytaus aps. viršininko ịstaigoje ir kitur ${ }^{8}$. Su statybos batalionu atsidūręs Leningrado srityje, $1943 \mathrm{~m}$. rudeni perbėgo pas sovietu partizanus, kovojo ju gretose, taip pateko i Raudonają armiją, "atgailaudamas" parašè plačius parodymus apie lietuvių statybos batalionus. 1944 m. pabaigoje Vilniaus garnizono Karinio tribunolo buvo nuteistas $10 \mathrm{~m}$. kalèti ${ }^{9}$.

Nemažai faktų ir duomenų apie statybos batalionų veiklą yra Lietuvos ypatingajame archyve (toliau - LYA): buvusių karių "filtracinèse" (baudžiamosiose) bylose, parodymuose KGB tardytojams, kaltinamosiose išvadose, nuteistų karių bylų peržiūrèjimo (reabilitavimo) dokumentuose ir kt. Rašant straipsni, panaudota 1-ojo lietuvių statybos bataliono karininko Antano Natkevičiaus ir kitu šio bataliono karių baudžia-

${ }^{8}$ Apie J. Borevičių žr.: Masinès žudynès Lietuvoje 1941-1944: Dokumentų rinkinys, d. 2, Vilnius, 1973, p. 48- 49, 53, 61,71-72; J. Borevičiaus “Gyvenimo aprašymas” [ 1944m.], LVOA, f. 1, ap. 1, b. 99, 1. 81-85; J. Borevičiaus 1961. 04. 21d. parodymai KGB, ten pat, f. 3377 , ap. 55 , b. $155,1.87$.

${ }^{9}$ Borevičiaus J. baudžiamoji byla. LYA, f.K-1, ap. 58, b. 44908/3. Borevičiaus J. parodymai / 1944m./ , LVOA , f. 1, ap. 1, b. 98, 1. 28-66; b. 99, 1. 1-39; kitų statybos batalionų karių parodymai: Oginto A. 1944. 06. 14d. parodymai: užrašè R. Šarmaitis, ten pat, b. 100, 1. 1-9; Oginto A. 1944. 05. 18d. parodymai: apklausė Prūsaitis, ten pat, b. 99, 1. 40-51; Bitaičio A. 1944. 05. 15d. parodymai: apklausẻ B. Baranauskas, ten pat, b. 99, 1. 58-63; Calkos A. 1944. 05. 16d. parodymai: apklausė B. Baranauskas, ten pat, b. $98,1.80-90$; b. $99,1.86-96$ ir kt. 
mosios bylos duomenys ${ }^{10}$, LVOA saugomi išrašai iš kitų batalionų karių parodymų KGB tardytojams.

Tačiau KGB šaltiniai vienpusiški, juose daugiausia dėmesio skirta statybos batalionų karių kovai su sovietų partizanais, jų ivvykdytiems "nusikaltimams", represinio pobūdžio akcijų metu padarytiems civiliams gyventojams. Nei viena, nei kita nebuvo lietuvių statybos batalionų karių svarbiausios veiklos sritys.

Trumpai apžvelgus tyrinėjamos temos archyvinius ir kitus šaltinius, apibendrintai galima pasakyti: Lietuvos archyvuose beveik nėra pirminių, pačių statybos batalionų karių karo metais rašytų dokumentų (îsakymų, raportų ir pan.), trūksta objektyvių, informatyvių ir patikimų šaltinių. Daugelis jų vienpusiški ir tendencingi. Matyt, tai yra viena iš svarbiausių priežasčių, kad lietuvių statybos batalionų istorija iki šiol mažai tyrinèta ir nušviesta.

Šio straipsnio tikslas - remiantis ivvairiais šaltiniais, kritiškai juos analizuojant ir vertinant, nušviesti lietuvių statybos (inžinerijos) batalionų kūrimosi Lietuvoje $1943 \mathrm{~m}$. istorines aplinkybes, veiklos pobūdị rytuose, jų karių likimą ir kitus su batalionų istorija susijusius klausimus, pažvelgti į šių karinių dalinių istoriją kaip ị atskirą lietuviškų karinių formuočių, dalyvavusių Vokietijos-SSRS kare, istorijos puslapi. Nepaisant to, kad statybos batalionai buvo palyginti negausi karinè formuoté, jų veikla tiesiogiai nesisieja su sudetingais ir tragiškais nacių Vokietijos okupacijos laikotarpio Lietuvos istorijos ịvykiais ir procesais (pvz., tokiais kaip lietuvių savisaugos batalionų akivaizdus dalyvavimas žydų žudynių ar kitose represinėse akcijose prieš civilius gyventojus), i juos negalima žiūrèti kaip į nereikšmingą lietuvišką karinę formuotę, o i jų istoriją - kaip ị specifinę, neįdomią ir neaktualią.Tam tikrais atžvilgiais statybos batalionų veikla reikšmingumo prasme išsiskiria iš kitų vokiečių okupacijos metais Lietuvoje suformuotų lietuviškų karinių dalinių: tik savisaugos ir statybos batalionai buvo siunčiami ị Rytus, veikẻ ten pafrontès sąlygomis, kovojo su sovietų partizanais ir kt. Statybos batalionu formavimas ir siuntimas i Rytus buvo vokiečių okupantų pastangų mobilizuoti Lietuvos vyrus besąlygiškai kovai už Vokietijos reicho interesus sudedamoji dalis. Ir atvirkščiai - kova su jų formavimu ir panaudojimu lietuvių tautos siekių neišreiškiantiems tikslams, apskritai kova prieš vo-

${ }^{10}$ LYA, f. K-1, ap. 58, b. 42013/3.

232 
kiečių karines mobilizacijas Lietuvoje buvo vienas svarbiausių nacionalinio antinacinio pogrindžio veiklos tikslų.

Pateikta straipsnyje medžiaga kai kuriais statybos batalionų istorijos klausimais ( pvz., apie jų formavimo aplinkybes 1943 m. pavasarị) gali būti įdomi skaitytojui ir platesne - naciu okupacinès, represinès politikos, apskritai to meto ịvykių Lietuvoje pažinimo - prasme.

Straipsnis iliustruotas nuotraukomis ir dokumentų faksimilėmis iš vokiečių okupacijos metais Lietuvoje leistų laikraščiu ir žurnalų, taip pat nuotraukomis iš Sakalo Natkevičiaus asmeninio archyvo. Jo tèvas Antanas Natkevičius (1904-1965) buvo Lietuvos kariuomenès atsargos karininkas, 1943-1944m. - 1-ojo lietuviu statybos bataliono, suformuoto Kaune, kuopos vadas, leitenantas. Deja, po išsaugotomis vertingomis nuotraukomis nėra jokių užrašų, kurie padètų tiksliai atskleisti jose užfiksuotus ịvykius ir žmones. Galima spèti, kad nuotraukose užfiksuota Lietuvos karo mokyklos technikos specialybės kariūnų aspirantų rengimo ir Lietuvos kariuomenès pionieriu gyvenimo 1927-1929 m. laikotarpiu akimirkos. Autorius nuoširdžiai dėkoja S.Natkevičiui už leidimą paskelbti šias nuotraukas.

\section{Nuo SS legiono iki statybos batalionu}

Kalbant apie lietuvių statybos batalionų formavimą 1943 m. pavasarị, reikia bent trumpai atkreipti dėmesị i keletą įžanginio pobūdžio principinių dalykų. Pradeję karą ir "išvadavę" SSRS pavergtas Rytu Europos tautas, Vokietijos naciai nesiruošé toleruoti jų politinių, valstybingumo atkūrimo siekių, iš jų gyventojų formuoti nacionalinių karinių dalinių vermachto sudètyje. "Pabaltijo erdvèje" neturèjo būti leista atsikurti ir "Lietuvos valstybei" bei jos institucijoms, taip pat ir kariuomenei. Pasinaudoję Rytu Europos tautu karine pagalba politine prasme, naujieji okupantai būtụ "susirišse" sau rankas ateityje sprendžiant šiu tautų likimą, būtų atsiradę politinių nuolaidų iliuzijų, kurios būtų trukdžiusios jų imperiniams, kolonizaciniams tikslams šiame regione. Nacių supratimu, nacionalinės karinės formuotės, kovojusios vermachto sudètyje su bolševizmu, būtų simbolizavusios šių tautu valstybingumo siekius, Vokietijos sajungininko kare statusą ir kt. Be to, negalima pamiršti, jog Vokietijos naciai prieš SSRS planavo pergalingą "žaibo karą", taigi okupuotų tautụ pagalba neatrodė jiems reikalinga ir karine prasme. Dėl šių priežas- 
čių jie atmetė Lietuvos Laikinosios vyriausybès pasiūlymą organizuoti lietuvių "tautinị korpusą", kuris dalyvautų "kryžiaus žygyje” prieš bolševizmą, neleido jokia kita forma atsikurti Lietuvos ginkluotoms pajẻgoms, išskyrus pagalbinio, policinio pobūdžio formuotes - Litauische Schutzmannschaft, t.y. savisaugos batalionus, turejusius veikti SS ir policijos žinioje, nes, nacių supratimu, policijos formuotès ne taip kaip nacionaliniai kariuomenès daliniai, jos nebuvo politinių valstybinių siekių, valstybingumo simboliai ir turèjo atlikti tik pagalbinio pobūdžio funkcijas organizuojant tvarkos palaikymą fronto užnugaryje ir kt.

Lietuvių aktyvistų fronto ( LAF'o) vadovybė ir Laikinoji vyriausybẻ lietuviškų karinių formuočių steigimą ir apskritai karinị bendradarbiavimą su Vokietija įsivaizdavo su sąlyga, kad ji juridiškai ir faktiškai pripažins Lietuvos valstybès suverenumą, bent ribotą nepriklausomybę, satelitinị Lietuvos statusą Vokietijos atžvilgiu. Tokių nuostatų nesilaikẻ Lietuvių nacionalistų partija (LNP), ejusi ị glaudesnius kontaktus su vokiečiais, nereikalavusi "tuoj pat”, nedelsiant atkurti bent dalini Lietuvos valstybingumą, iš esmès sutikusi su jų nuostata, kad Lietuvos valstybès atkūrimas būtų sprendžiamas po karo, nugalëjus "bolševizmą". Tačiau net ir LNP protestavo prieš vokiečių "nenorą leisti išsilaisvinusiai Lietuvos valstybei dalyvauti istorinėje kovoje už Naujosios Europos ateitị" "atskiru daliniu", sudarytu iš "savanorių - partizanų ir Lietuvos armijos likučių”. (Lietuvių nacionalistai turẻjo savų, skirtingų nuo Laikinosios vyriausybės ir LAF'o, kuriame dominavo krikščionys demokratai, lietuviškų karinių formuočių kūrimo planų). Tašiau ir jie savanorių verbavimo ir pagalbinès policijos tarnybos batalionų, kurie priklausytų policijai, o ne vermachtui, nelaike politiškai tinkama "Lietuvos dejjimosi į Naujosios Europos kūrimą" forma, nes jai "nesuteikiama jokios ateities prasmès"11.

Nacių okupantų politinès nuostatos ir interesai, "žaibo karo" planai lèmé tai, jog iki 1941m. pabaigos net ir lietuvių pagalbinès policijos (savisaugos) batalionų dalyvavimas "kryžiaus žygyje prieš bolševizmą" buvo nutylimas. Antai laikraštyje "İ laisvę" (nuo 1943 m.- "Ateitis") rašyta: "Nors iki šiol nebuvo paskelbta, bet buvo žinoma, kad lietuvių savanorių batalionai stovi sargyboj petis ì petị su vokiečiu policija" ${ }^{12}$.

\footnotetext{
${ }^{11}$ Metmenys Lietuviu nacionalistu partijos ruošiamo pro memoria Reicho vyriausybei Berlyne, $L C V A$, f. R.-1520, ap. 1, b. 2, 1. 4, 10; LVOA, f. 3377, ap. 55, b. 38, 1. 80.

${ }^{12}$ Mūsų batalionus palydint. I laisvę, 1941, lapkrišio 7, Nr. 117, p. 6. 
Daugelis lietuvių karių, karo pradžioje tikejęsi, kad vokiečiai leis atsikurti Lietuvos valstybei ir jos kariuomenei, ir stoję i savisaugos batalionus kaip i atsikuriančias Lietuvos ginkluotąsias pajègas, turèjo skaudžiai nusivilti vokiečiu šiems batalionams skirtu "pagalbinès policijos" statusu ir vaidmeniu. Tai ryškiai atsispindi 5-ojo lietuvių savisaugos bataliono, 1941 m. rudenị išsiųsto ị vokiečiu Šiaurès frontą ir ten pasižymèjusio kovojant su sovietų partizanais ir Raudonaja armija, vadovybės 1942 m. rašte vokiečių karinei vadovybei. Jame skųstasi, kad "tarptautinès teisès atžvilgiu Lietuvos kareivis yra visai beteisèje padètyje, nes jo šiame kare dalyvavimo Vokietija viešai nedeklaravo", schutzmannschaft-o institucija vertinta kaip pusiau civiline, pusiau policine, "laikina, nepastovi ir nežinoma". Lietuviai kariai norejo kovoti Rytu fronte "petis ị petị" su vokiečių kariais, o ne su policininkais ir būti vertinami kaip lygiaverčiai sajungininkai. Ilgas rašte išdẻstytų priekaištų vokiečiams dẻl lietuvių karių padèties ir diskriminavimo faktų sąrašas užbaigiamas vaizdžia išvada: "po karo bus sunku ịrodyti, kad fronte buvo būta"13.

Pradejjus blogèti paděčiai fronte, ypač po pralaimèjimo prie Stalingrado 1943 m. pradžioje, Vokietijoje paskelbus vadinamają "totalinę mobilizaciją", pradèta igyvendinti visa sistema nepaprastuju priemonių, kurių tikslas buvo ịtraukti ne tik Vokietijos reicho, bet ir visų okupuotų kraštu žmones ir materialinius išteklius karo reikmėms tenkinti. Naciai buvo priversti daryti savo politinių, rasistinių, karinių nuostatų pataisas ir okupuotų Rytų Europos tautų atžvilgiu. Pirmiausia estams, vèliau latviams ir lietuviams suteikta "garbė" steigti nacionalinius Waffen SS (Ginklų SS) kariuomenès junginius (legionus). Lietuvių tautai tokia "garbė" ir teisè suteikta Ostlando reichskomisaro H. Lohsės $1943 \mathrm{~m}$. vasario 24 d. paskelbtame atsišaukime ị lietuvius. İdomu pažymèti, jog H. Lohsė nevartojo termino "lietuviu legionas" - jis ragino stoti ị "savo tévynès legioną". Terminas "lietuvių legionas" pirmą kartą paminètas šiek tiek vèliau A. Rentelno, E. Justo ir SS policijos vado Lietuvoje L. Vysockio atsišaukime "Lietuviai prie ginklo"14.

Kaip šiuos vokiečiu nacių nuostatų pokyčius vertino Lietuvos visuomené? Kai Vokietija pačioje karo pradžioje neleido atkurti Lietuvos valstybingumo, ịvedè civilinę okupacinę valdžią, didžioji Lietuvos visuo-

${ }^{13}$ Zizas R. Lietuvos kariai savisaugos batalionuose (1941-1944m.), Lietuvos archyvai: Straipsniu ir dokumentu rinkinys, kn.11, Vilnius,1998, p. 65, 69.

${ }^{14}$ Ateitis. 1943, vasario 24, Nr. 45, p. 1; vasario 27, Nr. 48, p. 1. 
menès dalis ir susiformavęs nacionalinis antinacinis pogrindis buvo griežtai nusistatę prieš visus nacių okupantų bandymus įtraukti Lietuvą i besąlygišką dalyvavimą kare Vokietijos pusèje, tvirtai laikèsi tarptautine teise pagrịstos nuostatos, jog tik suverenios Lietuvos vyriausybé gali skelbti ir vykdyti Lietuvos gyventojų karinę mobilizaciją. SS legiono steigimą 1943 m. vasarị lietuvių antinacinis pogrindis vertino kaip Lietuvos jaunimo masinès mobilizacijos pradžią, jo pasmerkimą kovai ir žūčiai už Vokietijos interesus Rytų fronte, apskritai kaip vieną iš rimčiausių istorijos išbandymų, gyvybinị klausimą "žūti ar išlikti”"15.

Nors lietuvių politinių, karinių, net ir pogrindžio veikèjų nusistatymas SS legiono atžvilgiu nebuvo visiškai vienareikšmiškai negatyvus, būta svyravimų (patys ị legioną užsirašè ir už jị apskritai agitavo plk. A. Birontas, gen. K. Navakas, Panevėžio apskrities viršininkas plk. A. Gaušas, ịžiūrẻdamas galimybę atkurti Lietuvos kariuomenę svyravo gen. S. Raštikis), registracijos i ji rezultatai, daugiausia dèl pogrindžio įtakos, buvo katastrofiškai menki.

Apibendrinamojo pobūdžio duomenų, kiek iš viso Lietuvos vyru užsirašė ị SS lietuvių legioną, istoriografijoje nėra. Vokiečiai iš savisaugos batalionų ir viešosios policijos ị legioną užrašė 1093 vyrus, iš jų 286 patys panoro jame tarnauti. Naujų savanorių i SS legioną buvo labai nedaug: užsirašiusių i ji ̌ Šakių ir Raseinių aps. - po 3, Mažeikių ir Telšių aps. - po 5, Eišiškių ir Kèdainių aps. - po 1, Alytaus aps. $-4^{16}$, Tauragės mieste $-7^{17}$.

SS legiono steigimo nesėkmé Lietuvoje buvo didelis politinis ir moralinis smūgis vokiečiu prestižui, politikai ir propagandai, "totalinės" kovos su bolševizmu interesams, juo labiau kad Latvijoje ir Estijoje nacionaliniai SS legionai buvo sėkmingai suformuoti, latviai ir estai, "ịsijungę ị kovą su bolševizmu” vokiečių propagandos lietuviams buvo nurodomi sektinu pavyzdžiu. İsakymą dèl latvių SS legiono formavimo A. Hitleris pasirašè 1943 m. vasario 10 d. 1943-1944m. šị legioną sudarẻ dvi SS Waffen latvių divizijos - 15-oji ir 19-oji. Estijoje suformuotas SS estų legionas (20-oji Waffen SS divizija), jame buvo apie 11 tūkst. vyrų ${ }^{18}$,

\footnotetext{
${ }^{15}$ I Lietuvos girių sūnus. Laisvès kovotojas. 1943, kovo 18.

${ }^{16}$ Rukšènas K., min. veik., p.57-58.

${ }^{17} L C V A$, f. R-1476, ap.1, b.139, 1.36.

${ }^{18}$ Misiūnas R., Taagepera R. Baltijos valstybès: priklausomybès metai, 1940-1990, Vilnius,1992, p.63.
} 
neskaitant daugybès kitų estų karinių ir policinių formuočių.

Kokią tragediją latvių ir estų tautoms reiškẻ "įsijungimas ị kovą su bolševizmu”, frontinių SS kariuomenès junginių suformavimas, akivaizdžiai matyti iš tokio pavyzdžio: Latvijoje į vokiečių kariuomenę iš viso buvo įtraukta beveik 150 tūkst. vyrų, iš jų, oficialiomis žiniomis, žuvo apie 60 tūkst. ${ }^{19}$

Dèl SS legiono nesėkmès Lietuvoje “įsižeidę" ir įtūžę vokiečiai griebèsi gerai žinomų represijų - buvo uždaryti universitetai ir kitos aukštosios mokyklos, ị Štuthofo koncentracijos stovyklą išvežti 46 Lietuvos kultūros ir visuomenès veikèjai, griebtasi bauginimų, grasinimų vykdyti griežčiausias bausmes.

Nacių okupacinio režimo pareigūnai Lietuvoje 1943 m. kovo 17 d. paskelbtame pareiškime, grèsmingai apkaltinę "tam tikrus intelektualinius sluoksnius", "atsakingus asmenis" nusikaltimais ne tik prieš "savo lietuvių tautos", bet ir vokiečių tautos, "kuri visas savo jëgas mobilizavo totaliniam karui", net ir "Europos tautu bendruomenès" interesams, oficialiai atsisakẻ steigti SS lietuvių legioną. Deklaravus toki atsisakymą, pareikšta, jog "registracija ateityje vyks jau tik darbams kariuomenei ir karo ūkiui" 20 .
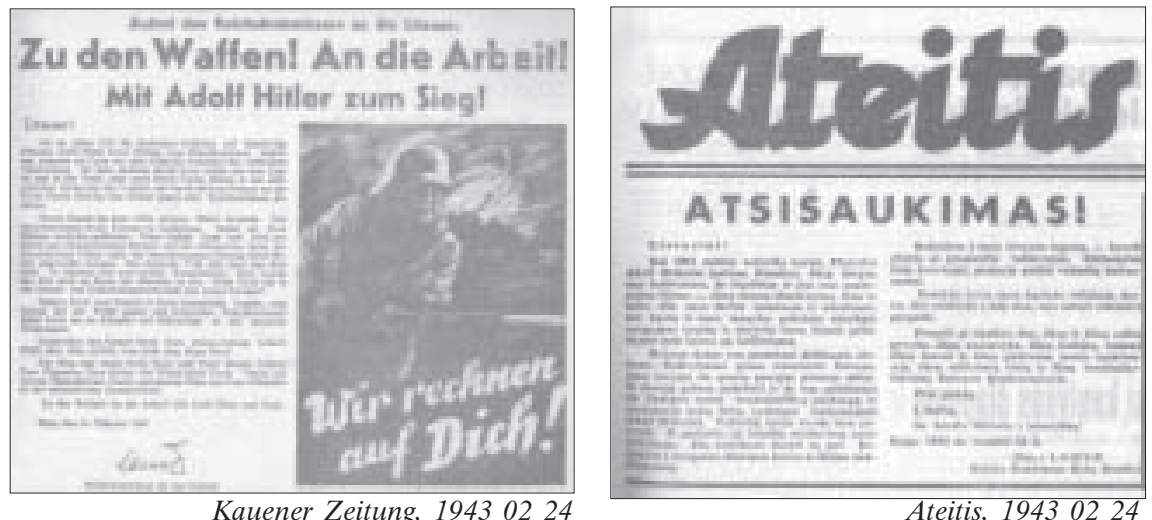

Oslando reichskomisaro H. Lohsès atsišaukimas, raginantis lietuvius stoti ị SS legioną. Atsišaukime vokiečių k. lietuviai kviečiami: "Prie ginklo! İ darbą! Su Adolfu Hitleriu i pergalę!" Plakato apačioje užrašas "Mes pasitikime Tavimi".

${ }^{19}$ Stinkulis V. Ir tai yra tautos drama: Pernelyg daug esame kovoję su svetimomis vèliavomis, Šiaurès Atenai, 1998, kovo 28, Nr.12 (406), p.8. Versta iš Latvijas vestnesis, 1998, kovo 12-13. ${ }^{20}$ Ateitis. 1943, kovas 17, Nr. 63, p. 1. 


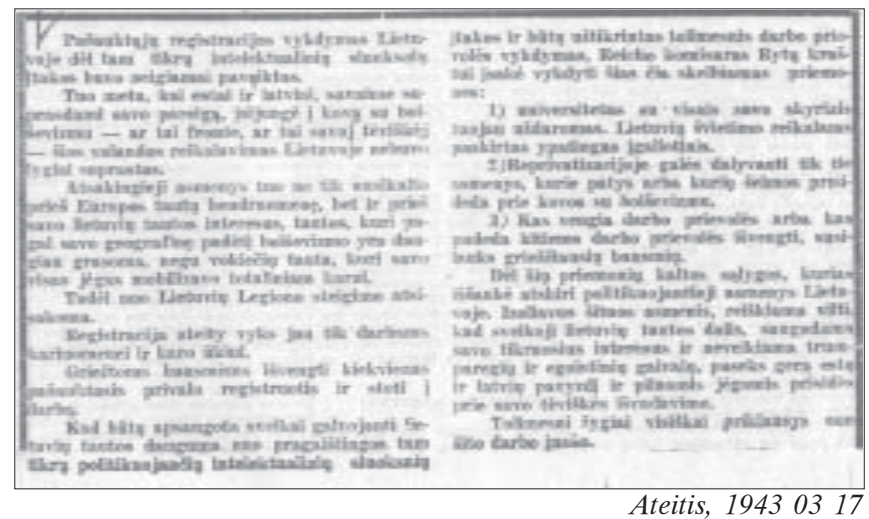

Lietuviai neatsiliepè ị vokiečių raginimus. Skelbimas apie atsisakymą steigti SS legioną ir imti Lietuvos vyrus tik darbams kariuomeneje ir karo ūkyje

Šią nacių okupantų principinę nuostatą ir tolesnius bandymus kitais būdais ir ị kitas karines formuotes mobilizuoti Lietuvos vyrus, galima laikyti esminiu išeities tašku atsirasti lietuvių statybos batalionams. Okupantų mobilizacinès pastangos Lietuvoje nukrypo i pagalbinių, ne fronto karinių dalinių (tokie ir buvo statybos batalionai) kūrimą. Šių batalionų kūrimas, iš dalies Lietuvos vyrų ėmimas ị vokiškus karinius (pvz., į vadinamuosius priešlèktuvinès gynybos) dalinius, ūkinès prievolès, žmonių vežimas darbams į Vokietiją tapo pagrindinemis lietuvių tautos priverstinio dalyvavimo kare Vokietijos puseje formomis, kurios padejo išsaugoti gyvybini tautos potencialą, Lietuvos jaunimą - nuo dalyvavimo ir neišvengiamos žūties Vokietijos-SSRS karo frontuose. Prasidejus "totalinei mobilizacijai” (nuo 1942 m. pabaigos iki 1943 m. pradžios), Latvijoje ir Estijoje suformavus nacionalinius SS kariuomenės junginius, kurie aktyviai kovėsi ir liejo kraują Rytų fronte, okupuotos Lietuvos dalyvavimas kare Vokietijos pusėje iš principo pradėjo skirtis nuo šių ir daugelio kitų Vokietijos okupuotų tautų dalyvavimo kare formų. Iš kitos pusės, Latvijos ir Estijos gyventojai daug mažesniu mastu negu Lietuvos vežti darbams i Vokietiją. Lietuvių statybos (inžinerijos) batalionų formavimas $1943 \mathrm{~m}$. pavasarị ir jų siuntimas ị Rytus leido išeiti iš nepaprastai sunkios ir grèsmingos situacijos, kuri susidare sužlugus SS legiono kūrimo planams. Statybos batalionams buvo lemta tapti savotišku, nors toli gražu ir nelygiaverčiu, SS legiono pakaitalu, tam tikra "kompensacija" vokiečiams už jų sužlugdytas dideles mobilizacines užmačias bei izžeistas ambicijas. Statybos batalionų suformavi238 
mas kartu su kitomis nuolaidomis vokiečių okupantams 1943 m. pavasarị padejjo išsaugoti ir pačią lietuviškų karinių formuočių kūrimo vokiečių karinėse ir policinèse žinybose idejją, kurios realizavimui, boikotavus SS legioną, iškilo reali grèsmè. Vokiečiai Lietuvoje galëjo nueiti ne lietuviškų nacionalinių formuočių kūrimo keliu, o mobilizuoti lietuvius tiesiogiai ị savo karinius ir policinius dalinius, kaip tai daré, pavyzdžiui, su lenkais okupuotose Lenkijos teritorijose, nekalbant jau apie grèsusi masini Lietuvos gyventojų vežimą darbams į reichą. Vokiečiai nesuteikẻ lenkams "garbės" kovoje prieš bolševizmą turèti savo nacionalinius karinius dalinius ir jų neformavo, tačiau labai daug lenkų buvo mobilizuota tiesiogiai ị vokiečių vermachtą. Antai Raudonosios armijos karinès žvalgybos duomenimis, $1942 \mathrm{~m}$. lenkai sudaré net apie 40-45 proc. vokiečių 96-osios péstininkų divizijos, apie 30 proc. 11-osios pėstininku divizijos, kartu su čekais - apie 30 proc. 57-osios péstininkų divizijos, apie 12 proc. 110-osios pėstininkų divizijos kareivių ${ }^{21}$. Lenkai nebuvo vokiečiams ištikimi "sajungininkai”, masiškai perbėginejo ị Raudonosios armijos pusę, tačiau vokiečių vadovaujami buvo priversti lieti kraują už jų interesus. Lietuvos politiniams ir kariniams (net ir antinacinio pogrindžio) veikëjams, siekusiems išsaugoti jaunimą, puoselejusiems viltis turèti ir išsaugoti ginkluotų pajëgu branduolị ir jų pagrindu susiklosčius palankioms aplinkybèms atkurti Lietuvos kariuomenę, "lenkiškasis" kelias buvo nepriimtinas.

Iš tyrinètų šaltinių nèra visiškai aišku, kada atsirado statybos batalionų kūrimo idejja. Galima manyti, kad iš pat pradžių - kartu su SS legiono steigimo ir kitais dideliais "totalinès mobilizacijos" Lietuvoje planais. Antai pogrindinis laikraštis "Nepriklausoma Lietuva” 1943 m. vasario mėnesi rašè, kad tvarkos policijos vadas išleido įsakymą, kuriuo 17-45 m. amžiaus Lietuvos piliečiai vyrai ịpareigojami neapibrèžtą laiką dirbti "sustiprinimo darbus” Rusijoje. Tam Lietuvoje turejjo būti paimta daugiau kaip 3 tūkstančiai vyrų. Vyrai, imami vasario 4-15 d., skirstomi šimtinėmis, joms vadovauti pavedama aktyviosios tarnybos policininkams ${ }^{22}$. Matyt, sužlugus SS legiono steigimo idejjai, mobilizacijai "sustiprinimo", t.y. karinių ịtvirtinimų statybos, darbams ir juos vykdančių karinių statybinių dalinių - statybos (inžinerijos) batalionu - formavimui buvo lemta tapti pagrindiniu, svarbiausiu okupantų mobilizacinių pastangų tikslu.

Lietuvių statybos batalionų organizatorius ir "globejjas" buvo gen.

${ }^{21}$ Справочник боевых характеристик немецких дивизий (на 1.6.1943) : Главное разведывательное управление Красной армии. Москва, 1943, с.13, 21, 31, 49, 53.

${ }^{22}$ Lietuviai. Nepriklausoma Lietuva. 1943, vasario 15, Nr. 3(15), p. 2. 
mjr. Emilis Justas, vokiečių vyriausiasis karo komendantas Lietuvoje. 1943 m. kovo 20 d., praejjus keletui dienų po oficialaus vokiečių atsisakymo steigti SS legioną, “Ateityje” pasirodė E. Justo atsišaukimas, kuriame buvo skelbiama: "Kad būtų palengvintas Rytuose vykstančios kovos prieš bolševizmą, man ịsakyta vokiečių kariuomenei suorganizuoti lietuvių inžinerijos (statybos) batalionus, kurie būtų naudojami būtiniems karo darbams tolimesniame fronto užnugaryje”. Paskelbęs atsišaukimą, E. Justas prièmė keletą lietuvių karininkų, kandidatų ị statybos batalionų vadus: plk. Itn. J. Ugianskį, kapitonus Slyvėną ir A. Milaševičių. Priẻmimo metu E. Justas pareiškè "džiaugsmą ir savo padèką už atsiliepimą i jo pakvietimą”, pateike "plačius paaiškinimus” apie planuojamus formuoti batalionus: jie priklausys išimtinai vokiečių kariuomenei, jų uždavinys - statyti įtvirtinimus "fronto srityje”, visi karininkai, puskarininkiai ir kareiviai būsią lietuviai, jie dėvės vokiečių kariuomenės uniformą su "ypatingais laipsnių ženklais", ị batalionus bus priimami 20-45 m. amžiaus savanoriai lietuviai, buvo pageidaujami sveiki, stiprūs, vidutinio amžiaus vyrai ir t. t. ${ }^{23}$ Kodèl būtent gen. mjr. E. Justas ėmèsi lietuvių statybos batalionų organizatoriaus vaidmens, savo atsiminimuose aiškina vyskupas V. Brizgys: Lietuvoje vokiečių civilinè valdžia ir gestapas konfliktavęs su kariuomene. Lietuvos karo komendantas Justas tai panaudojęs savo prestižui. Jis pasiūlè lietuviams mobilizuoti nors vieną darbo batalioną ir tuo įrodyti, kad lietuviai nėra "prorusiški", o tik nepritaria civilverwaltungo politikai ir taktikai ${ }^{24}$.

Dèl E. Justo prestižo ir autoriteto 1943 m. Lietuvoje galima ginčytis. 1938-1940 m. jis buvo Vokietijos karo ir aviacijos atašè Kaune. 1942 m. pavasari kartu su generaliniu komisaru A. Rentelnu jis pasirašè atsišaukimą, kuriame ragino Lietuvos vyrus registruotis ị "transporto tarnybą", šis atsišaukimas susilauke griežtos lietuvių antinacinio pogrindžio kritikos ${ }^{25}$. 1943 m. vasarị, praejjus vos keletui dienų po H. Lohsès atsišaukimo pasirodymo, kartu su A. Rentelnu, SS ir policijos vadu Lietuvoje L. Vysockiu buvo pasirašęs atsišaukimą, raginusi lietuvius stoti į SS legioną. Taigi ar

${ }^{23}$ Karo komendanto Lietuvoje gen. mjr. Justo atsišaukimas. Ateitis. 1943, kovo 20, Nr. 66, p. 1; Pranešimas; Lietuvos saugumo srities komendanto İsidėmètinas pranešimas lietuvių inžinerijos (statybos) batalionų nariams .Ten pat. 1943, kovo 23, Nr. 68, p.1; Pranešimas: steigiami lietuvių inžinerijos (statybos) batalionai vokiečių kariuomenès vadovybejje. Karys. 1943, kovo 27, Nr. 13, p. 5.

${ }^{24}$ Vysk. Brizgys V. Gyvenimo keliai. Vilnius, 1993, p. 105.

${ }^{25}$ Dar viena begėdiška klasta ir pasityčiojimas. Lietuvių tautinio fronto biuletenis. 1942, gegužès 10, Nr. 1, p. 1-2. 
nebuvo E. Justo, vieno iš aukščiausių nacių pareigūnų Lietuvoje, autoritetas susvyravęs? Kita vertus, gen. mjr. E. Justo pareigybinė padėtis Lietuvoje nuo kitų okupacinio režimo pareigūnų formaliai iš tikrujų skyrẻsi, - jis buvo vermachto atstovas, o vermachtui, kaip rašè įtakinga krikščionių demokratu spauda, "vis dèlto mes dar turime gan šiltų simpatijų"26.

E. Justo atsišaukimas ir mobilizacinès kalbos savo turiniu niekuo nesiskyrè nuo kitu nacių pareigūnų atsišaukimų ir kalbų, jose nebuvo jokių politinio pobūdžio pažadụ, tačiau jo bendravimo su lietuviais tonas buvo subtilesnis ir švelnesnis.

1943 m. kovo 20 d. prie Kauno ịvyko iškilmingas atsisveikinimas su pirmaisiais vokiečių kariuomenès talkininkais lietuviais. Iškilmėse pasakytoje kalboje E. Justas kreipèsi i juos pagarbiu kreipiniu "mano lietuviai draugai", kalbẻjo apie lietuvių "nelaimingą Tẻvynę", kvietè išlydimus lietuvius "užtikrinti savo Tẻvynei gražią ateitị" ir "naujais savo darbais" parodyti, jog jie yra verti vokiečiu pagarbos ir pasitikèjimo. Baigdamas kalbą siūlè "lietuviškos tévynès gerovei" sušukti triskart "valio" ir kt. Pirmasis generalinis tarejas gen. P. Kubiliūnas ten pat sveikino lietuvius "karo talkininkus", perejusius "vermachto žinion, generolo Justo tẻviškon globon"27.

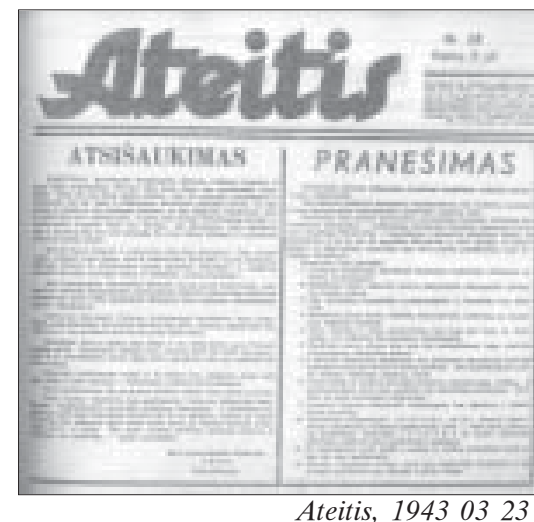

Gen. E. Justo atsišaukimas, kviečiantis lietuvius stoti ị inžinerijos (statybos) batalionus, ir pranešimas apie pirmo bataliono formavimą

${ }^{26}$ Lietuviu fronto biuletenis. 1943, lapkrišio 26, Nr. 11, p. 6.

${ }^{27}$ Generolo majoro Justo atsisveikinimo žodis talkininkams. Ateitis. 1943, kovo 20, Nr. 66, p. 1; Gen. Kubiliūno žodis šiandien išlydėtiems Wehrmachto talkininkams. Ten pat. 

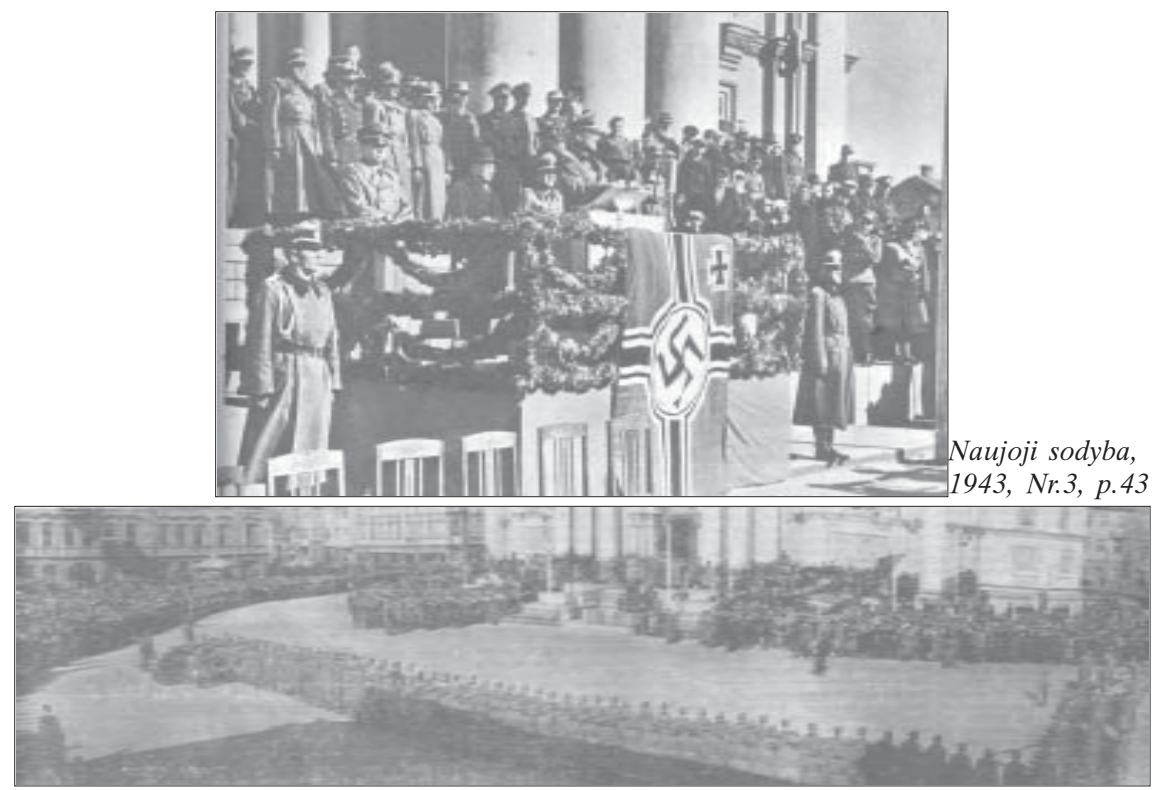

Kauener Zeitung, 19430323

Po nepavykusio bandymo suformuoti SS legioną iškilmingas pirmujų karo talkininkų išlydejjimas į tarnybą vermachte, 19430320 Kaune prie Igulos bažnyčios (Soboro). Nuotr.: bendras iškilmių vaizdas; viršuje - vainikais ir Vokietijos reicho vèliava papuoštoje tribūnoje gen. E. Justas, už jo nugaros - P. Kubiliūnas, vokiečių ir lietuvių karininkai

Objektyviai tokị pagarbų gen. E. Justo ir sušvelnèjusi kitų vokiečių pareigūnų toną lèmè pradėję šlyti reikalai karo frontuose, atgarsio Lietuvoje nesulaukę raginimai stoti ị SS legioną. İdomu pažymėti, kad pats iškilmingas palyginti negausaus (apie 120 pirmųjų "karo talkininkų") būrio išlydèjimas ị tarnybą vermachte oficialiojoje spaudoje propagandiniais sumetimais vadintas "neeiline, didinga demonstracija" prieš bolševizmą ir lietuvių tautos ryšių "sustiprinimu” su Vokietijos vermachtu. Pirmieji "karo talkininkai" turejo būti pavyzdžiu "naujiems lietuvių vyrų būriams", kurie gen. E. Justo šaukiami turejo stoti ị statybos dalinius $^{28}$.

${ }^{28}$ Atsisveikinimas su pirmaisiais lietuviais vokiečių kariuomenès talkininkais. Ateitis. 1943 kovo 22, Nr. 67, p.4. 
Antra vertus, nacių pareigūnai Lietuvoje, tarp jų ir gen. E. Justas, ir toliau kèle "besąlyginio" lietuvių tautos dalyvavimo kovoje "prieš bolševizmą" reikalavimus. Viename iš daugelio straipsnių, paskelbtų "Ateityje" 1943 m. pavasarị, demagogiškai tvirtinta, jog ir Vakarų Europos valstybės aktyviai dalyvauja kare prieš bolševizmą, visai nekeldamos klausimo "dèl atlyginimo bei kokių nors kompensacijų", politiniai reikalai "atidèti ị šalį", jie "tebèra neišspręsti ne tik Lietuvos, bet ir kitu valstybiư", jie "visoj pilnumoj" bus sprendžiami tik po karo, tada, "reikia tikètis, ras vietos ir mūsų krašto reikalai". "Svarbiausias dalykas" lietuviams turejo būti tai, kad į kovą juos "kviečia vermachtas" (o ne SS ir policijos ar vokiečiu okupacinès civilinès administracijos pareigūnai - R.Z). Straipsnyje buvo raginama pasitiketti "pono generolo Justo garbingu žodžiu ir jo tèviška globa" 29 .

İdomu pažymėti, jog E. Justo asmenybė, jo atsišaukimas ir pats statybos batalionų kūrimas buvo palankiai vertinamas krikščionių demokratų ir jų veikiamų rezistencijos organizacijų pogrindžio spaudoje. Antai laikraštyje "İ laisvę" buvo rašoma: "Kitos rūšies batalionus ir kitaip ėmé organizuoti karo komendantas gen. mjr. Justas. Jis, ilgiau Lietuvoje gyvenęs, lietuvius geriau pažindamas, pakvietė lietuvius ị statybos ir inžinerijos batalionus. Savo atsišaukime jis mokejo i lietuvius prašnekti kaip i kultūringus žmones ir ịvertinti jų praeities žygius tėvynei ginti. Toks žmoniškas kreipimasis susilaukẻ kitokių rezultatų: atsirado savanorių, kurie ryžtasi dar kartą įrodyti, kad jie nori atkakliai kovoti su bolševizmu, jeigu i juos kreipiamasi kaip i žmones, bet ne kaip i gaudomus žvėris: "jeigu būtų pagerbta ir jų tėvynè, atsižvelgiant ị jos brangiausius siekimus, kurių patenkinimas nieko nesukliudytu karui, tai savanoriais stojimas būtų masinis".Vokiškų mobilizacijų neišvengusiems Lietuvos vyrams kiek vẻliau laikraštyje "I laisvę" buvo rekomenduojama: "rinktis, pirmiausia, lietuvių karinius dalinius, kurie žadama sudaryti, o toliau gen. Justo technikos ir statybos batalionus, tik paskiausia darbo prievolée ${ }^{30}$.

Net ir dalies ịtakingų rezistencijos sluoksnių palankų nusistatymą ir retoriką gen. mjr. E. Justo asmenybès ir statybos batalionų kūrimo atžvilgiu, be jau minètų aplinkybių, susijusių su siekiais turèti lietuviškas karines formuotes, lėmè slogi, sudètinga, įtempta padètis, susiklosčiusi

${ }^{29}$ Pulk. J.B. Wehrmachto šaukiami. Ateitis. 1943 kovo 31, Nr. 75, p. 1.

${ }^{30}$ Batalionai. I laisvę.1943, balandžio 1, Nr.5, p.4; Konferencija nieko nepakeitè. Ten pat, 1943, balandžio 12, Nr. 6, p. 1 . 
po SS legiono sužlugdymo ir vokiečių ịvykdytos represijos. Tai vertė daryti tam tikras nuolaidas okupantams, ieškoti kompromisų, švelninti kategorišką poziciją ir nuostatas dèl jų reikalavimų, laikytis nuosaikesnès santykių su vokiečiais linijos. Tokios pozicijos (nors ir ne visuotinos) motyvus glaustai galima būtų apibūdinti taip: tolesnių, dar griežtesnių ir radikalesnių represijų baimé, pavojus atsidurti nacių žiauriai persekiojamos "lenkų tautos padètyje" ${ }^{1}$, netekti, nors ir nedidelių, politinių teisių: ribotos "savivaldos", jau suformuotų lietuviškų karinių pajėgų - savisaugos batalionų, kuriuos vokiečiai galëjo išformuoti. Antra vertus, nefrontinių nacionalinių dalinių kūrimas vermachto sudetyje atrode gera alternatyva SS kariuomenės daliniams, net ir iki tol daugiausia policines funkcijas vykdžiusiems savisaugos batalionams. Pagaliau reikejjo atsižvelgti ir ị okupacinio režimo pareigūnų siekius "garbingai" išeiti iš susidariusios padèties, nedestabilizuoti jos palyginti visiškai ramiame ir strategiškai svarbiame vokiečiams užnugario krašte.

Visas šias idėjas kaupe ir visų îvykių raidą pakreipti vokiečiams palankesne linkme stengèsi gen. P. Kubiliūno vadovaujamas lietuviškosios "savivaldos" (administracijos) aparatas, ypač jo vadovaujančioji viršūnė. Jos požiūriu, Lietuvos vyrų, visų pirma gimusių 1919-1924 m., pašaukimas ị karo tarnybą 1943 m. pavasarị po SS legiono sužlugdymo Lietuvai turèjo "lemiamą reikšmę", nuo kurios priklausẻ krašto ir visos tautos likimas ir ateitis, kitos išeities paprasčiausiai nebuvo.

Padèties švelninimo, kompromisinių sprendimų paieškas tarp vokiečių ir lietuvių interesų (iš esmès vokiečiams padarytas nuolaidas) atspindejo vadinamosios visos Lietuvos atstovų konferencijos, vykusios 1943 m. balandžio 5 d. Kaune, Karo muziejuje, nutarimai (rezoliucijos). Konferencijos darbe dalyvavo apie 90 žymesnių visuomenés veikejjų, parinktu iš visos Lietuvos. Prof. M. Biržiškos vadovaujama konferencija priėme 3 rezoliucijas (jas vokiečiai taisè ir redagavo), jose svarbiausia buvo tai, kad "lietuvių tautos vardu" pareikštas pasiryžimas prisidèti prie Vokietijos reicho "milžiniškos" kovos su bolševizmu, pritarta savanoriškais pagrindais suformuotų ir lietuvių karininkų vadovaujamų ginkluotų Lietuvos dalinių organizavimui, visi lietuviai paraginti "nedelsiant atlikti ịpareigojimus karinès reikšmès darbe" ${ }^{32}$. Konferencijos nutarimai, juose už-

${ }^{31}$ Matulionis J. Neramios dienos. Toronto, 1975, p. 238; Konferencijos eiga. Nepriklausoma Lietuva. 1943, gegužès 1, Nr. 7(19), p. 2.

${ }^{32}$ Konferencijos nutarimai. Ateitis. 1943, balandžio 6, Nr. 80, p. 1; Tautos atstovų balsas. Ten pat. 1943, balandžio 8, Nr. 82, p. 1; Rezoliucijos. Karys. 1943, balandžio 10, Nr. 15, p. 1. 


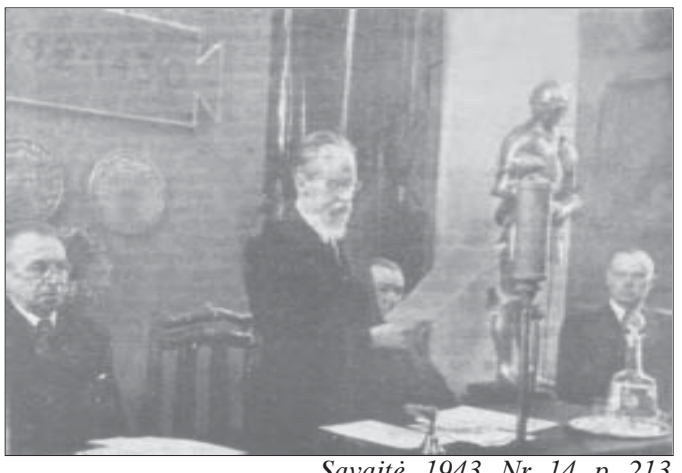

Vadinamoji visos Lietuvos atstovų konferencija: Nuotr.: kaireje konferencijos prezidiumas: iš kairès gen. V. Nagius, konferencijos pirmininkas prof. M. Biržiška, A. Pimpè, P. Kubiliūnas; Nuotr. apačioje - bendras salès vaizdas;

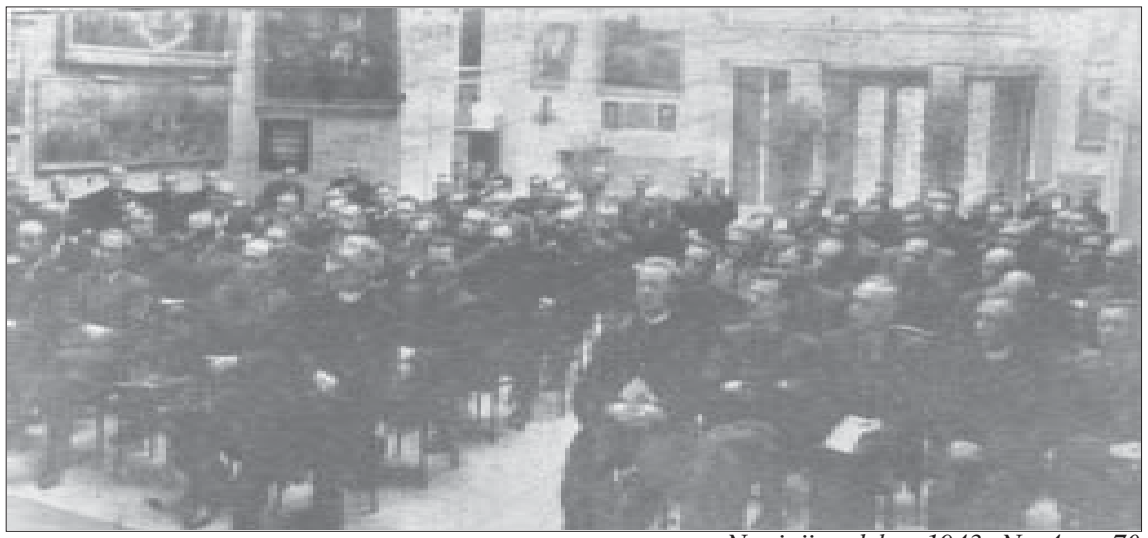

Naujoji sodyba, 1943, Nr. 4, p. 70

Konferencijos prezidiumo nariai pas Lietuvos generalini komisarą A. Rentelną: iš kairès penktas A. Rentelnas, toliau Ropas, P. Kubiliūnas, M. Biržiška, gen. V. Nagius

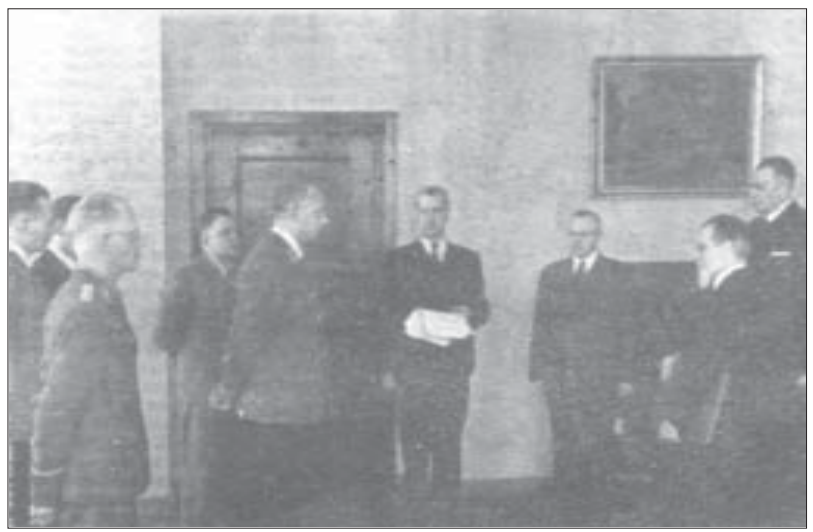

Savaite, 1943, Nr. 14, p. 213 
fiksuotos nuolaidos susilauke griežtos lietuvių antinacinio pogrindžio kritikos ( ji pašiepiamai vadinta " 2-uoju liaudies seimu”, "okupaciniu seimu”), jų reikšmė tolesniems ịvykiams Lietuvoje buvo prieštaringa (istoriografijoje ji beveik neaptarta). İdomus pačių vokiečių vertinimas: konferencija "labai sumažino įtempimą" ir bent formaliai pademonstravo lietuvių tautos valią dalyvauti kovoje prieš bolševizmą, bet ị ją dètas viltis mažai pateisino ${ }^{33}$. Galima teigti, kad konferencija ir jos nutarimai okupantams suteikė tam tikrą "teisinị” ir moralinị pagrindą siekti savo tikslų, mobilizuojant ị karinę tarnybą Lietuvos vyrus, visų pirma ị pradètus formuoti lietuvių statybos batalionus.

Iš tyrinètų šaltinių nėra aišku, kiek statybos batalionų vokiečiai ir lietuvių "savivaldos" pareigūnai planavo suformuoti. Gen. E. Justas savo atsišaukime kvietė lietuvius stoti i inžinerijos (statybos) batalionus, bet tuo pačiu laiku (dažnai kartu) skelbtuose oficialiuose okupacinės valdžios "pranešimuose" buvo kalbama apie vieno bataliono steigimą. Tai, kaip minèta, liudija vyskupas V. Brizgys bei kiti šaltiniai ${ }^{34}$. Matyt, lietuviams apvylus vokiečius su SS legiono steigimu, šie buvo atsargūs. Tačiau po vadinamosios visos Lietuvos atstovų konferencijos ir jos palyginti palankių vokiečiams sprendimų lietuvių statybos batalionų formavimas išsiliejo ị didelio užmojo okupantų mobilizacines akcijas, kurias realizuojant Lietuvos vyrai buvo imami ne tik i juos, bet ir i grynai vokiškus, daugiausia vadinamuosius priešlèktuvinès gynybos dalinius, nekalbant jau apie ėmimą darbams ị reichą. Keitèsi ir statybos batalionų formavimo pobūdis, - nuo savanoriško į juos stojimo, deklaruoto gen. E. Justo 1943 $\mathrm{m}$. kovo $22 \mathrm{~d}$. atsišaukime, pereita prie plataus masto prievartinių metodų.

\section{Organizacinės, agitacinės ir represinės akcijos formuojant statybos batalionus ir jų rezultatai}

Remdamasis konferencijos nutarimais, Lietuvos generalinis komisaras A.T. Rentelnas 1943 m. balandžio 6 d. "Ateityje" stambiu šriftu išspausdintame skelbime pareikalavo registruotis 1919-1924 m. gimusius

\footnotetext{
${ }^{33}$ Nacionalistu talka hitlerininkams. Vilnius, 1970, p. 111.

${ }^{34}$ Žr.: Dokumentai Lietuvos vietinès rinktinès istorijai: sudarė Z. Raulinaitis, Chicago, 1990, p. 64-65.
} 
Lietuvos vyrus (registracijos laiką turejjo nurodyti apskričiu viršininkai ir miestų burmistrai), nesiregistravusiems grasino "sunkiomis bausmèmis (kalẻjimu, sunkiujų darbų kalèjimu arba priverčiamojo darbo stovykla)"35.

Tą pačią dieną pirmasis generalinis tarèjas $\mathrm{P}$. Kubiliūnas išleido potvarki 1919-1924 m. gimusiems vyrams registruotis "lietuvių šaukimo komisijose", jame ne tik pakartojo A. Rentelno grasinimus nesiregistravusiems, bet užsiminè ir apie "aukštesnes bausmes" (1919-1924 m. gimusių vyrų registracija vokiečių ir antinacinio pogrindžio dokumentuose vadinta "pirmaja mobilizacija").

1943 m. birželio 10 d. A. Rentelno pavaduotojo K. Nabersbergo atsišaukimu ir P. Kubiliūno potvarkiu paskelbta 1912-1918 ir 1925 m. gimusių vyru registracija ${ }^{36}$ (ji vadinta "antraja mobilizacija"). Antinacinio pogrindžio šaltinių duomenimis, šioms mobilizacijoms pavykus, okupantai ruošèsi skelbti ir 1900-1911 m. gimusių vyrų registraciją, tačiau oficialiai ji nebuvo paskelbta.

Statybos batalionams formuoti svarbus buvo P. Kubiliūno $1943 \mathrm{~m}$. balandžio $6 \mathrm{~d}$. potvarkis surengti buvusios Lietuvos kariuomenès karininkų, viršilų ir puskarininkių surašymą: privalèjo registruotis karininkai iki $60 \mathrm{~m}$. amžiaus, viršilos, puskarininkiai, net ir grandiniai, baigę puskarininkių mokyklas, iki $45 \mathrm{~m}$. amžiaus. Nesiregistravusieji turejjo būti baudžiami piniginèmis baudomis iki $1000 \mathrm{rm}$ arba suėmimu iki 30 parų $^{37}$. A. Rentelno pavaduotojo K. Nabersbergo 1943 m. balandžio 13 d. skelbimu reicho darbo tarnybai privalëjo registruotis abiturientų ir gimnazijų paskutiniųjų klasių mokiniai, gimusieji 1923-1924 m..$^{38}$

Pažymėtina, jog 1919-1924 m. gimusių vyrų surašymas iš esmès paskelbtas pakartotinai, šio amžiaus vyrus buvo mėginta suregistruoti ir 1943 $\mathrm{m}$. vasario mèn. bandant formuoti SS legioną. Skirtumas tik tas, kad tada mobilizacijos komisijos iš esmès buvo sudarytos iš vokiečių, iš lietuviụ i jas įejo tik apskričių viršininkai arba jų pavaduotojai, jų darbe turejo dalyvauti ir valsčiu viršaičiai. Antai registruojant ị SS legioną Tauragejje, komisiją sudare komisijos vadovas vokietis karininkas, generalinio komisaro atstovas, apskrities viršininkas, vokiečių policijos atstovas, vyres-

\footnotetext{
${ }^{35}$ Registruokitès patikrinimo punktuose! Skelbimas visiems 1919-1924 metais gimusiems vyrams. Ateitis. 1943, balandžio 7, Nr. 81, p. 1

${ }^{36}$ Ateitis. 1943, birželio 11, Nr. 134, p. 1.

${ }^{37}$ Karys. 1943, balandžio 17, Nr. 16, p. 4.

${ }^{38}$ Skelbimas: Pranešimas dèl darbo tarnybos. Ateitis. 1943, balandžio 15, Nr. 88, p. 6.
} 
nysis gydytojas ir 3 pagalbiniai gydytojai. Kartu su pagalbiniu personalu (vertèjais, raštininkais ir kt.) komisijoje buvo 26 žmonès ${ }^{39}$. Po nesėkmès su SS legionu, daug žadejusių visos Lietuvos atstovų konferencijos nutarimų ir P. Kubiliūno minèto $1943 \mathrm{~m}$. balandžio 6 d. potvarkio mobilizacijos darbai ir atsakomybè už ją patikèti lietuvių savivaldai, jai leista "kuo plačiausiai" vadovauti mobilizacijai. Iš "savivaldos" pareigūnų apskrityse sudarytos komisijos turèjo važinėti po valsčius ir vykdyti Lietuvos vyru mobilizaciją. Tačiau lietuviškosios komisijos nebuvo savarankiškos, jos veikẻ kartu su vokiečių mobilizacijos štabais, sudarytais apskrityse. Antai vokiečių mobilizacijos štabo Nr. 23 (vok. - Musterungsstab 23) Tauragėje vadovas 1943 m. balandžio 19 d. rašte Tauragès apskrities viršininkui Vl. Mylimui nurodė, jog vyrų šaukimas šioje apskrityje turi prasidėti balandžio 19 d., pagal suderintą planą valsčių viršaičiai kiekvieną šaukimo dieną privalejjo atvesti i komisijas po 60 vyrų $^{40}$.

Mobilizacijos darbų patikèjimas "savivaldai” ir lietuviškosioms komisijoms buvo tam tikra okupantų nuolaida, turejusi prisidéti prie jos sėkmės. Nežinomas rezistencijos šaltinio autorius aprašė 1919-1924 m. gimusių vyrų registracijos eigą Marijampolès aps. Igliškẻlių valsčiuje: vyrus registravo valsčiaus viršaitis, gavęs įsakymą iš apskrities viršininko. Vyrų sąrašai sudarinèti padedant seniūnams. Jie nurodinėjo, kas privalo registruotis, o kas ne. Registracija vyko blogai, nes buvo "didelių neaiškumų”, kas ją skelbia - ar lietuviai, ar vokiečiai lietuvių vardu. Iš pasikalbẻjimų su daugeliu vyrų išaiškẻjo jų pozicija: jei tikrai registracija skelbiama lietuvių, jie ị ją eina "mielu noru", bet kartu ir bijosi, kad nebūtų apvilti, kaip "daugelị kartų" jau yra ịvykęet

Vokiečiu pareigūnų supratimu, didelè "nuolaida" buvo generalinio komisaro Lietuvoje A. T. Rentelno minètas $1943 \mathrm{~m}$. balandžio 6 d. skelbimas, kuris vertintas kaip "tyli” amnestija ị SS legioną nesiregistravusiems 1919-1924 m. gimusiems Lietuvos vyrams, nes jie neturèjo būti persekiojami. Pasak Panevéžio apygardos komisaro V. Noimo (W. Neum), "Vokietijos valstybè šia "kilnia amnestija” įrodé, kad su Lietuva nesielgiama

${ }^{39}$ Tauragès mobilizacinio štabo vadovo 1943.03 .03 ir 10 d. raštai Taurages aps. viršininkui, LCVA, f. R-1476, ap.1, b.139, 1.27, 11.

${ }^{40}$ Ten pat, 1.81.

${ }^{41}$ Pogrindinio "İ laisvę" laikraščio redakcijos rankraščiai ir kita informacinè medžiaga, LVOA, f. 3377 , ap. 58 , b. 263 , 1. 33 . 
kaip su okupuotu kraštu, kad padoriam lietuviui, nepaisant "mažos neatsakingos klikos provokacijų", dar kartą siūloma draugiška ranka"

Lietuvių "savivaldos" pareigūnai gerai suprato, kad atsakas ị vokiečių ištiestą "draugišką ranką" po nesẻkmès su SS legiono formavimu turéjo būti sèkmingas ir greitas lietuvių statybos batalionų organizavimas gen. E. Justo "tėviškoje globoje”. Todèl kai kurie ịvairiu grandžių lietuviškos administracijos pareigūnai labai stengèsi. Pogrindine "Nepriklausoma Lietuva" rašè, jog kai kuriose apskrityse vietos ar net iš centro (Kauno - R. Z.) atvykę pareigūnai važinejja po valsčius ir susirinkimuose agituoja stoti i batalionus, tie ponai atvyksta su apskričių saugumo viršininkais, tikėdamiesi labiau paveikti lietuvių nusistatymą ${ }^{43}$.

1943 m. kovo 21 d. Biržuose lankèsi pats pirmasis generalinis tarèjas gen. P. Kubiliūnas. Biržų apskrities visuomenès atstovų susirinkime jis padare "svarbų" pranešimą apie "šių dienų" padètị. Susirinkime išrinkti Biržu atstovai ị visos Lietuvos konferenciją, matyt, daug kalbeta ir apie statybos batalionų organizavimą. "N[aujosiose] Biržų žiniose" 1943 m. kovo 27 d. šalia E. Justo atsišaukimo paskelbtas ir Biržų aps. viršininko B.Pulkauniko raginimas stoti "ị kovą prieš bolševizmą", rašytis ị formuojamus lietuvių statybos (inžinerijos) batalionus. Apskrities viršininkas registruotis kvieté pas ji, nelaukiant, kol prièmimo komisijos pradès darbą balandžio 1-3 ir $5 \mathrm{~d}^{44}$. Tomis dienomis stojančiujų i statybos batalionus komisijos veiké Tauragès ir kitose apskrityse ${ }^{45}$. Tačiau propagandinè agitacinè statybos batalionų kūrimo kampanija visoje Lietuvoje išsiplète ir sustiprejjo tik $1943 \mathrm{~m}$. balandžio mėnesi, po minètos konferencijos.

P. Kubiliūno 1943 m. balandžio 10 d. telefonogramoje visiems apskričiu viršininkams ir miestų burmistrams nurodyta verbavimą į statybos batalionus baigti stebètinai greitai - iki balandžio 18 d. Joje akcentuota, jog labai svarbu, kad verbavimas pasisektų, apskričių viršininkai ịpareigoti važinejjant informacijos (propagandos) tikslais po apskritis paraginti žmones, ypač šaukiamojo amžiaus vyrus, rašytis ị batalionus. Batalionams

${ }^{42}$ Panevėžio apygardos komisaras posėdžiauja su vietos savivaldos pareigūnais. Panevėžio apygardos balsas. 1943, balandžio 24, Nr. 16(72), p. 1.

${ }^{43}$ Ir saugumas nepadeda. Nepriklausoma Lietuva. 1943, gegužès 1, Nr. 7(19), p. 4.

${ }^{44}$ Atsišaukimas. N. Biržų žinios. 1943, kovo 27, Nr. 12(66), p. 1; Lietuvių inžinerijos bataliono karių ėmimas ir aprūpinimas. Ten pat.

${ }^{45}$ Tauragès aps. viršininko Vl. Mylimo raštas (be datos) Tauragès miesto burmistrui. LCVA, f. R1476. ap.1, b.139, 1.62. 
dar trūko apie 2500 vyrų, t. y. apie 100 vyrų ir bent 2 karininkų iš kiekvienos apskrities ${ }^{46}$.

Nors lietuvių "savivaldai” mobilizacija i statybos batalionus geriau sekėsi, vis dẻlto Lietuvos vyrai vangiai ejjo ir ị lietuviškąsias komisijas, visi išankstiniai mobilizaciniai planai sužlugo. Tauragès apskrityje 1919-1924 m. gimusių vyrų šaukimas pradètas dviejuose valsčiuose: Gaurès valsčiuje - 1943 m. balandžio 19-20 ir 28-30 d. bei Skaudvilès valsčiuje - 1943 m. gegužès 1 d. Kaip buvo pažymima Tauragès aps. viršininko 1943 m. gegužès 5 d. rašte apskrities policijos vadui, abiejuose valsčiuose "labai mažai šaukiamųjų vyrų stojo komisijon" ${ }^{77}$. Panaši padėtis buvo ir kitose Lietuvos apskrityse.

Lietuvių "savivaldai" siekiant pagerinti, jos supratimu, Lietuvai lemiamą reikšmę turëjusios mobilizacijos rezultatus, teko imtis skubių papildomų priemonių, taip pat ir represinių veiksmų. Pirmasis generalinis tarèjas P. Kubiliūnas 1943 m. gegužès 4 d. telefonograma visus apskričių viršininkus, Kauno, Vilniaus, Šiaulių ir Panevėžio miestų burmistrus ịpareigojo 1919-1924 m. gimusių vyrų šaukimą ịvykdyti su "visu atsidejjimu”. Toliau telefonogramoje buvo nurodoma: " Kiekvienas šaukiamasis turi būtinai stoti šaukimo komisijon. Už tai, kad kiekvienas šaukiamasis vyras būtų paimtas, neša atsakomybę apskričių viršininkai, valsčių viršaičiai, burmistrai ir seniūnai. Jie privalo pritaikinti nestojusiems numatytas bausmes ir panaudoti visas kitas priemones, kurios tam bus reikalingos. Nestojusiems bausmę îvykdyti apskrities viršininkas panaudoja vietos policiją. Nestojusiems ir jų šeimoms bus taikomos ir paskutinès priemonès suėmimai, nušalinimai nuo ūkių ir konfiskavimai kito turto”. Telefonograma turejo būti paskelbta Lietuvos gyventojams ${ }^{48}$.

Kita tos pačios dienos telefonograma, Nr. 20, P. Kubiliūnas ịpareigojo apskričių viršininkus iš "patikimų ir garbingų" visuomenès atstovų apskrityse sudaryti 5-6 žmonių propagandos grupes ir "skubiausiu laiku" visuose valsčiuose surengti propagandinius susirinkimus. I juos turèjo būti kviečiami seniūnai, viršaičiai, mokytojai bei dvasininkai, po 2 atstovus iš kiekvieno kaimo, juose turẻjo būti “ịtikinamai” išaiškinta, kad šaukimai i kariuomenę yra "būtinai reikalingi mūsų krašto išgelbėjimui ir saugios

\footnotetext{
${ }^{46}$ Nacionalistu talka hitlerininkams, p. 110.

${ }^{47}$ LCVA, f.R-1476, ap.1, b.139, 1.105.

${ }^{48}$ Nacionalistu talka hitlerininkams, p.113; LCVA, f. R-1476, ap.1, b. 139, 1.104.

${ }^{49}$ LCVA, f. R-1476, ap.1, b.139, 1.99.
} 
ateities užtikrinimui”, išaiškintos sankcijos, kurios "neatmainomai gresia kiekvienam, kuris nuo šaukimo slèpsis ir kuris šaukiamaji slèps”. Telefonogramoje tvirtinta, kad latviai ir estai jau turi sumobilizavę 87 proc. šaukiamų vyrų, todèl ir lietuviai neturi nuo jų atsilikti, kitaip "mūsų tautai visu rimtumu pražūtis graso" ${ }^{49}$.

Taigi P. Kubiliūnas 1943 m. gegužès pradžioje pradëjo grasinti ir gąsdinti nestojusius i komisijas vyrus "paskutinėmis”, tai yra griežčiausiomis bausmėmis, kartu išryškejjo, apie kokio pobūdžio represines priemones - "aukštesnes bausmes" - jis buvo užsiminęs prieš mẻnesi paskelbtame potvarkyje. Reikia pažymėti, kad iki tol Lietuvoje represinès priemonès vykdant mobilizacijas plačiau nenaudotos, išskyrus Lietuvos inteligentų kaip "garbės kalinių" (ịkaitų) suėmimą ir išvežimą i i Štuthofo koncentracijos stovyklą ir kitų akcijų po SS legiono formavimo nesėkmès. Dabar tarp bausmių buvo numatyta iš esmès nusikalstamų priemonių realizavimo sistema - "kolektyvinès atsakomybès" principo taikymas, įkaitų ėmimas ir kt., kai už nestojusius į komisijas turëjo atsakyti (nukentèti) tèvai, kiti šeimos nariai, žmonès, padèję besislapstantiems ir kt.

Kaip apskričiu viršininkai vykdè $\mathrm{P}$. Kubiliūno instrukcijas ir jose numatytas bausmes, matyti iš Tauragès apskrities viršininko Vl. Mylimo veiksmų. Jis 1943 m. gegužès 5 d. raštu ịpareigojo Tauragès aps. policijos vadą skubiai įsakyti Gaurès ir Skaudvilès policijos nuovadoms suimti visus nestojusius ị komisijas šių valsčių vyrus ir pristatyti ị komisijas, kurios dar turëjo dirbti kituose Tauragės aps. valsčiuose, dažnai tikrinti nestojusiųų gyvenamąsias vietas, įspèti jų tẻvus ir artimuosius dẻl gresiančių griežtų bausmių. Jo rašte buvo smulkiai detalizuota represinių priemonių taikymo procedūra: "neradus šaukiamojo namuos, sulaikyti tẻvą, nesant tèvui, - motiną, nesant motinai, - kitą artimiausią giminaiti ir laikyti arešte vietoje, kol šaukiamasis patsai atvyks policijon. Per savaitę šaukiamajam neatvykus, sulaikytą už šaukiamaji pristatyti i Tauragès arešto namus tolesniam parédymui". Visi vietos administracijos pareigūnai ir "kitų žinybų" tarnautojai ịpareigoti teikti žinias ir visokeriopą pagalbą policijai, "priešingai pasielgus", grasinta juos dar griežčiau bausti ${ }^{50}$.

Iš tyrinėtų šaltinių nėra aišku, kas taip smulkiai detalizavo ir sukonkretino P.Kubiliūno nurodymus: Tauragès aps. viršininkas ar tai buvo padaryta vokiečių okupacinio režimo ir P. Kubiliūno administracijos pa-

\footnotetext{
${ }^{49}$ LCVA, f. R.-1476, ap.1, b.139, 1.99.

${ }^{50}$ Ten pat, 1.105 .
} 
reigūnų. Galima manyti, kad toks represinių priemonių detalizavimas ėjo iš "viršaus" - vokiečių ir lietuvių "savivaldos" viršūnių, jos turejo būti vykdomos visoje Lietuvoje.

1943 m. gegužès 8-12 d. Tauragès aps. Gaurès valsčiuje veikè atvykęs mišrus vokiečių žandarmerijos ir lietuvių policijos 26 vyrų būrys, kuris, padedamas vietos policijos, suėmé vieną besislapstantị nuo mobilizacijos vyrą ir septynis besislapstančiujuc vyrų tévus - 5 tèvus ir 2 motinas. Tačiau nè vienas besislapstančių šaukiamujų, kurių vienas iš tẻvų buvo suimti, $i$ komisijas neprisistaté, todèl suimtieji išgabenti $i$ Tauragès arešto namus "tolesniam parėdymui" ${ }_{1}$. Toliau suiminėti žmones atsisakyta, nes valsčiaus areštinejje nebuvo jiems laikyti vietos. Vẻlesni vietos policijos besislapstančių "ieškojimai liko be pasekmių".

Tokio pobūdžio represijas $1943 \mathrm{~m}$. gegužès mėn. vokiečių žandarmerijos ir lietuviu policijos būriai (jie vadinti "specialiosiomis komandomis") vykde daugelyje Lietuvos vietovių. Antinacinio pogrindžio šaltiniuose užfiksuotas atvejis, kai Kaišiadoryse buvo suimta ir išvežta ị kalẻjimą Vilniuje dviejų nesiregistravusių sūnų motina. Ji buvo smarkiai sumušta, grịžo ligonè, tačiau paleista, nors sūnūs komisijoje ir neužsiregistravo ${ }^{52}$.

Gegužès 29-30 d. per gaudynes Kretingoje tarp daugelio kretingiškių buvo suimtas ir nuvarytas ị kalėjimą 55 metų amžiaus J. Gedgaudas dèl to, kad i mobilizacijos komisiją neatvyko jo sūnus ir kt. ${ }^{53}$

Kolektyvinès atsakomybès principas taikytas ir kitais būdais. Kauno apygardos gebitskomisaro A. Lenceno ịsakymu gegužès mėn. Kaune iš neatvykusių i mobilizacijos komisijas jaunuolių tèvų ir giminių, pas kuriuos jie gyveno, buvo atiminejjami butai: žmonès savo butus privalèjo palikti per 48 val., nepaklusę îsakymui buvo iškraustomi prievarta ${ }^{54}$.

Represinès priemonès buvo neefektyvios, lietuvių policijos ir kitų "savivaldos" pareigūnų dalyvavimas jose kèlè didelị visuomenès pasipiktinimą, sulaukè griežtos antinacinio pogrindžio spaudos kritikos. Pogrindinèje "Nepriklausomoje Lietuvoje" 1943 m. gegužès ménesi pasirodẻ straipsnelis iškalbingu pavadinimu "Gana, p. Kubiliūnai”. Laikraščio žodžiais, Lietuvos pirmasis generalinis tarẻjas "išdrįso" imtis "bolševikų prak-

\footnotetext{
${ }^{51}$ Tauragès aps. policijos Gaurès punkto vedejo 1943.05.17 d. raportas aps. policijos vadui. Ten pat, 1.117 .

${ }^{52}$ LVOA, Dokumentų rinkinys Nr.167, p.33.

${ }^{53}$ Rukšènas K. min. veik. , p. 63.

54 Ten pat, p.62.
}

252 
tiškai vartotų" priemonių ir buvo "paskutini kartą" įspètas. Laikraščio teigimu, "sukèlè audrą" ir P.Kubiliūno telefonogramą gavę "savivaldos" pareigūnai, todèl "bolševikinės" praktinès priemonès "prieš lietuvių šeimas" buvo atšauktos ${ }^{55}$.

Matyt, iš tikruju vokiečių okupacinio režimo ir P. Kubiliūno vadovaujamos "savivaldos" pareigūnai, $1943 \mathrm{~m}$. pavasarị pabandę griebtis masiškesnių represijų prieš nestojusius ị mobilizacines komisijas vyrus ir jų šeimos narius, pradėję taikyti "kolektyvinès atsakomybės" bausmès principą (imti ịkaitus vietoj nestojusiujų, konfiskuoti ūkius ir kt.), buvo priversti jų atsisakyti. Sudėtingomis $1943 \mathrm{~m}$. aplinkybėmis išryškẻjo prieštaringas, nevienareikšmis paties P. Kubiliūno ir viso jo "savivaldos" valdžios institucijų vaidmuo. Galima manyti, kad iš pradžių mėgindami įvykdyti, jų nuomone, Lietuvai daug "lemiančią" mobilizaciją, ịvairių, net ir griežčiausių bausmių šalininkai ir iniciatoriai buvo "savivaldos" pareigūnai. Tačiau susidūrę su visuotiniu pasipriešinimu mobilizacinėms pastangoms, "savivaldos" pareigūnai pradejjo dvejoti jų tikslingumu ir reikalingumu, veikè neryžtingai, "savivaldos" žemutinès grandys sabotavo represinių veiksmų vykdymą.

Inicijuoti tolesnes represines akcijas buvo priversti patys vokiečiai. Antai Siaulių apygardos gebitskomisaras H. Geveckẻ 1943 m. birželio $1 \mathrm{~d}$. aplinkraščiu apygardos apskričių viršininkus ir žemesnius pareigūnus ịpareigojo "visomis priemonemis pasirūpinti", kad vyrų registravimas ir tikrinimas būtu îvykdytas, turẻjo, kaip vaizdžiai aplinkraštyje pasakyta, "pasisekti ir paskutinį vyrą užregistruoti blogiausiame valsčiuje". Neatvykusieji ị patikrinimą turèjo būti tuoj pat suimami ir ịkalinami apskričiu kalëjimuose. Turẻjo būti suimami visi besislapstančių ir pabėgusių vyrų šeimų nariai, išskyrus ligonius ir senius bei vieną šeimos narị, paliktą žemès ūkio darbams. Išsiuntinètą aplinkraštị birželio $3 \mathrm{~d}$. H. Geveckè patikslino šiek tiek jị sušvelnindamas: šeimoms, kurių vienas sūnus tarnavo kariuomenèje, savisaugos daliniuose arba vokiečių ịstaigose, represijos neturèjo būti taikomos ${ }^{56}$.

Ir vis délto tokias žiaurias visuotines represines priemones vokiečiai Lietuvoje 1943 m. pavasarị ir vèliau mažai vykdè. Gaudynių, suėmimų, prievartinio išsiuntimo ị karinius dalinius neišvenge tik patys šau-

\footnotetext{
${ }^{55}$ Gana, p.Kubiliūnai. Nepriklausoma Lietuva, 1943, gegužès 15 d, Nr.8 (20), p.4.

${ }^{56}$ LVOA, f.3377, ap.58, b.265, 1.49.
} 
kiamieji vyrai, t.y. jiems taikytos individualios, o ne kolektyvinès bausmės, atsižvelgiant ị konkrečią, ịrodymais pagrịstą "kaltę" (kolektyvinès bausmès priemonių buvo griebiamasi tik Rytų Lietuvoje prieš lenkus, kai vietoj besislapstančių nuo išvežimo darbams į Vokietiją buvo suimami ir represuojami kiti jų šeimų nariai). Kyla klausimas - kodèl?

Nemažą įtaką tokiai situacijai turejjo minèta "savivaldos" institucijų, tokių kaip lietuvių policijos, pozicija. 1943 m. birželio pradžioje Telšių aps. viršininkas Ign. Šešplaukis praše Šiaulių apygardos gebitskomisaro nevykdyti minètų represijų, esą tikrinimo komisija "dėl trumpo laiko negalèjo visus atvykusius patikrinti”, siūlẻ vyrus dar kartą pašaukti registruotis ir tik po to imtis veiksmų ${ }^{57}$. Minèto vokiečiu mobilizacijos štabo Tauragėje vadas jau 1943 m. kovo 10 d. prašè apskrities viršininką įsakyti policijos vadui, kad lietuvių policija kasdien, ypač nakties metu, Tauragèje ir "žinomose slèptuvèse miškuose" ieškotų besislapstančių nuo registracijos i SS legioną vyrų, taip pat pageidavo, kad ateityje "policijos ieškojimas" turètų "konkrečiu pasekmių" 58 Tačiau "konkretūs" rezultatai taip ir liko menki.

Iš esmès atsakyti ị iškeltą klausimą padeda lietuvių statybos batalionų "šefo" gen. E. Justo 1946 m. parašyti parodymai KGB. Nušviesdamas padèti Lietuvoje 1943 m. pavasarị, jis rašè, kad po pirmosios nepasisekusios akcijos (mėginimų suformuoti SS legioną Lietuvoje -R.Z.) buvo griebtasi prievartos priemonių. Lietuviai ėmé masiškai bègti ị miškus: prieš tą bėgimą mažos policijos arba SD ir gestapo pajègos, krašto postai buvo bejègiai. SS ir policijos vyresnysis vadas Rygoje F. Jekelnas (F. Jeckeln) "piršo prievartos priemones", siūlè "kuriam laikui” Lietuvoje ịkurdinti vokiečių policijos brigadą, kad ji peršukuotų miškus, išgaudytų vyrus, kelis šimtus jų pagąsdinimui ir sudrausminimui sušaudytų, po to pabėgusiuosius prievarta atvestų i patikrinimo komisijas. Tačiau, anot E. Justo, F. Jekelnas tada neturejo savo dispozicijoje nei policijos pulko, nei bataliono, nes jo jëgas nuolat sekino kova su partizanais šiaurès Rusijoje ir Baltarusijoje ${ }^{59}$.

E. Justo parodymų teiginiai ne visiškai tiksliai atspindèjo realią $1943 \mathrm{~m}$. tikrovę (vokiečiai Lietuvoje dar mėgino vykdyti baudžiamąsias akcijas ir mišku valymus), tačiau atskleidžia bendrają ivvykių ir procesų raidos tendenciją: F. Jekelno ir kitų nacių pareigūnų siūlymams imtis Lietuvoje masinių rep-

\footnotetext{
${ }^{57}$ Ten pat.

${ }^{58} L C V A$, f. R.-1476, ap.1, b.139, 1.27.

${ }^{59}$ Laisvès kovu archyvas, t.9, Kaunas, 1993, p.149-150.
} 
resinių priemonių vokiečiai jau neturejjo jẻgų, jų vis labiau trūko rytuose kovai su išsiplètusiu partizaniniu judejimu. Kita vertus, represijų plėtimas grèse antivokiškos kovos (net ir ginkluotos) išsiplètimu ir pačioje Lietuvoje, kuri vokiečiams buvo svarbus jų frontą žemès ūkio produktais aprūpinantis kraštas, per kuri, be to, ejjo svarbios susisiekimo su frontu komunikacijos.

1943 m. vasarą, sustiprejus Lietuvoje nacių represinei politikai, lietuvių antinacinio pogrindžio radikalioji spauda priminè vokiečiams jų teroro veiksmų neperspektyvumą ir galimą ginkluoto pasipriešinimo alternatyvą pasyviajam pasipriešinimui. Pavyzdžiui, pogrindžio laikraštyje "Laisvès kovotojas” buvo rašoma: “... mes netikime, kad šitas grasomas teroras būtų panaudotas masiškai. Tuomet mūsų pasyvus pasipriešinimas pasidarytų labai aktyviu ir labai pavojingu ne tik okupacinès valdžios fazanams, bet ir kariuomenès reikalams". Toliau "Laisvès kovotojas" retoriškai klausė, ar tikrai Lietuvoje norima sukurti "rusišką padètị" "su partizanų ir sabotažnikų būriais" ${ }^{60}$

Be to, nereikia pamiršti, kad vokiečių represinius veiksmus varžè ir tarptautinès teisés nuostatos, draudžiančios okupuotame krašte vykdyti karines mobilizacijas.

Šios ir kitos aplinkybès lėmė tai, kad vokiečių įvairaus pobūdžio grasinimus, gąsdinimus ir bauginimus galima vertinti labiau kaip savitikslius dalykus, veiksmų metodą, kuriuo siekta palaužti lietuvių tautos pasipriešinimo dvasią, mobilizuoti Lietuvos vyrus, negu realiai planuotus ịvykdyti represinius veiksmus. Nacių okupantai prieš vengusius jų skelbtų mobilizacijų ir kitus sabotuotojus ịvykde nemažai represinių akcijų, antinacinio pogrindžio spaudoje dažnai vadintų "bolševikinèmis", tačiau jos neigavo tikrụjų bolševikinių represijų mastų, neprilygo represijoms, vykdytoms pokario metais prievarta mobilizuojant Lietuvos vyrus į Raudonają armiją.

Kalbant apie represines bei kitas spaudimo priemones, nulėmusias prievartini Lietuvos vyrų stojimą i statybos batalionus ir kitus karinius dalinius, negalima pamiršti ir kitų jų formavimo politinių sąlygų, motyvų ir aplinkybių, nesusijusių su prievarta ar vien tik vokiečių interesais. Visą nacių Vokietijos okupacijos laikotarpi gyvavo Lietuvos valstybingumo atkūrimo idèja, kartu ir siekiai turèti lietuviškas nacionalines karines formuotes, nors ir sudarytas kompromiso su okupantu būdu. Šie siekiai ir keliai jiems realizuoti, kaip rodo anksčiau pateikti pavyzdžiai (pa-

${ }^{60}$ Vergu gaudymas Naujajai Europai. Lietuviai ir lietuvès. Neikite ị nacių baudžiavą, Laisvès kovotojas. 1943, rugpjūčio 15. 
lankūs atsiliepimai apie gen. E. Justą), nebuvo svetimi net ir įtakingoms nacionalinio antinacinio pogrindžio jëgoms. Lietuviškos karinès formuotés, susiklosčius palankioms aplinkybėms, turèjo tapti pagrindu ir branduoliu atsikurti Lietuvos kariuomenei, ji turejjo sudaryti ne tik 1944 m. pradžioje bandyta suformuoti Lietuvos vietinè rinktinè, bet ir kitos anksčiau sudarytos lietuviškos formuotès, taip pat ir statybos (inžinerijos) batalionai.

Vokiečių ir lietuvių "savivaldos" mobilizacinès pastangos po nesèkmès bandant suformuoti SS legioną $1943 \mathrm{~m}$. taip pat buvo realizuojamos plètojant aktyvią propagandinę, agitacinę veiklą. Tokio pobūdžio priemonès, matyt, buvo efektyvesnès negu represinés akcijos. Kaip vyko propagandos ir agitacijos darbas, matyti iš Tauragès aps. pavyzdžių. Apskrities viršininkas Vl. Mylimas pagal parengtą iš anksto planą organizavo "propagandinius susirinkimus" (juose dalyvavo ir atvykęs vokiečių generalkomisariato propagandos vedèjas), juose skaityti "platūs pranešimai", kuriuose buvo aiškinamas mobilizacijos būtinumas ir raginama "stoti" i komisijas ${ }^{61}$.

1943 gegužès 6 d. Tauragèje, apskrities viršininko įstaigoje, sušauktas "vietos atstovų" susirinkimas. Jame dalyvavo Tauragès miesto burmistras, "Maisto" fabriko, gimnazijos, banko direktoriai, pradžios mokyklų inspektorius, du mokytojai, apskrities valdybos narys, profsajungų atstovas ${ }^{62}$. Iš šių "patikimų ir garbingụ" visuomenès atstovų buvo sudaryta propagandos grupe (komisija), kuri ir turèjo "itikinamai” aiškinti ir agituoti.

I propagandinę veiklą buvo stengiamasi ịtraukti ir Lietuvos katalikų bažnyčios dvasininkus. Bažnyčios hierarchijos ir paprastų kunigų pozicija tiek Lietuvos vyrų mobilizacijos atžvilgiu, tiek ir dvasininkijos dalyvavimo propagandinejje akcijoje klausimu nebuvo vienareikšmè, kunigai agituoti neskubëjo, tačiau, atsižvelgiant ị konkrečią situaciją ir psichologinę atmosferą, ji negalèjo būti nepalanki vokiečių okupacinès valdžios ir lietuvių "savivaldos" pozicijai. Arkivyskupas [ J. Skvireckas - R.Z.] paskelbė ganytojišką laišką prieš bolševizmą, vyskupas V. Brizgys pasakẻ per radiją kalbą, kurioje generolo majoro Justo pageidavimu kvietė stoti ị Vermachto statybos batalionus. Kai kurie dvasininkai taip pat pasakè "labai teigiamus" pamokslus prieš bolševizmą ir parèmé vokiečių interesus ${ }^{63}$.

\footnotetext{
${ }^{61}$ Tauragès aps. viršininko Vl. Mylimo 1943.05.19, 27 d. raštai Šiaulių apygardos gebitskomisarui ir pirmajam generaliniam tarejjui. $L C V A$, f. R-1476, ap. 1,6. 139, 1.118 - 119,112.

${ }^{62}$ Ten pat, 1.100 .

${ }^{63}$ Nacionalistu talka hitlerininkams, p.112.
} 
Kaip Lietuvos dvasininkija buvo spaudžiama ir verčiama agituoti, matyti iš tokių konkrečiu pavyzdžių. Tauragès aps. viršininkas $1943 \mathrm{~m}$. balandžio 9 d. raštu kreipèsi į Tauragès parapijos kleboną, prašydamas kuo greičiau visose bažnyčiose iš sakyklų paskelbti Lietuvos konferencijos nutarimus, paraginti, kad visi 1919-1924 m. gimę vyrai stotu jiems paskelbtu laiku ị šaukimo ir registravimosi komisijas, nesislapstytų, nes nebūsią i̇manoma "visą laiką išsislapstyti", kad nepasiduotų "bolševikų" agitacijai (taip, matyt, vadinta ir lietuvių nacionalinio antinacinio pogrindžio agitacija), nedarytu jokių akibrokštu ir kt. Kunigai prašyti "plačiau ir geriau" paaiškinti savo parapijiečiams susidariusią "sunkią Lietuvos padètị”"

Tauragés parapijos klebonas $1943 \mathrm{~m}$. balandžio $13 \mathrm{~d}$. atsakomajame rašte aiškino, kad, vadovaujantis "sena bažnytine tvarka", klebonai iš sakyklų skelbia tik tikejjimą ir dorą liečiančius klausimus bei grynai "parapijos reikalais pasitvarkymus". Visais kitais atvejais skelbimai daromi tik gavus tiesioginius nurodymus iš vyskupijos ordinariato. Tauragès parapijos klebonas sutiko skelbimą "mielai" paskelbti, jei gausiąs nurodymą iš Telšiu vyskupo.

Tauragès aps. Laukuvos policijos nuovados viršininkas, vykdydamas telefonu $1943 \mathrm{~m}$. balandžio $12 \mathrm{~d}$. gautą įsakymą, slaptu raportu informavo Tauragès aps. policijos vadą, kad Laukuvos klebonas praejjusi sekmadieni [balandžio 5 d.- R.Z.] pasaké pamokslą, kuriame vyrus ragino stoti i komisijas, aiškino, esą jeigu lietuviai neprisidès prie bolševikų sunaikinimo, gali susilaukti tokių pat ir dar žiauresnių laikų kaip po $1941 \mathrm{~m}$. birželio 15 d. ${ }^{65}$ (Šis faktas rodo, jog kunigai policijos buvo sekami ir kontroliuojami, ką skelbia iš sakyklų.)

Propagandiné, agitacinè kampanija rèmèsi propagandiniais štampais apie vokiečių ir lietuvių interesų bendrumą, bolševizmo pavojų lietuvių tautos egzistencijai, kovos prieš ji, kuriai nematyta alternatyvos, būtinumu ir kt. P. Kubiliūnas $1943 \mathrm{~m}$. balandžio 12 d. telefonograma visiems apskričiu viršininkams rekomendavo šaukiamujų registracijos vietose, taip pat gatvėse iškabinti plakatus, pasigamintus "vietos jègomis", su tokiais šũkiais:

"1. Registruodamiesi tarnybai ị kariuomenę ar karinès reikšmès darbus, palengvinsime Lietuvos padetį ir patikinsime jai ramybę ir saugumą.

\footnotetext{
${ }^{64}$ LCVA, f.R-1476 ap.1., b.139, 1. 75.

${ }^{65}$ Ten pat, 1.68, 126. Dokumente - "1943 m. birželio 15 d." Nėra abejonès, jog turètų būti "1941 m. birželio 15 d.”, turima omenyje sovietų vykdyti Lietuvos gyventojų trèmimai ir kitos represijos.
} 
2. Bolševizmas Lietuvą sunaikintų, jei pats nebus sunaikintas. Šaukiamieji registruotis, stokime į registracijos punktus.

3. Bolševizmas arba gyvybė. Lietuvių tauta išliks, jeigu sūnūs, kurie šaukiami registruotis, atliks savo pareigą"66.

Vokiečių propaganda lietuviams sektinu pavyzdžiu nurodẻ ne tik estus ir latvius, bet ir kovojančias prieš bolševizmą "kultūringas, mažas ir dideles" Europos tautas - suomius, vengrus, slovakus, rumunus, danus, norvegus, net ir prancūzus. "Mes, lietuviai, siekiame laisvės kultūringų Europos tautų bendruomenèje vadovaujant ašies valstybèms, bet jokiu būdu ne mums visiems pažįstamoje bolševikiškoje vergijoje", - buvo tvirtinama viename iš atsišaukimų ar jo projektų ${ }^{67}$.

Pogrindžio šaltinių tvirtinimu, Panevėžio apskrities viršininkas plk. A. Gaušas (jis buvo voldemarininkas, $1941 \mathrm{~m}$. karinès organizacijos "Geležinis Vilkas" vadas), agituodamas stoti ị batalionus, aiškino, jog reikia "pasitarnauti Lietuvai”, jo manymu, karas einąs ị pabaigą, jị laimésią vokiečiai, o jeigu ir nelaimèsią, - mobilizuoti vyrai bus "pradžia Lietuvos kariuomenei”, esą pats laikas ją pradèti kurti. Panevėžio apygardos komisaras V. Noimas labai gyręs plk. A. Gaušą, kitų apygardos apskričių viršininkams grasinęs už neveiklumą.

Antinacinis pogrindis, ypač jo radikalusis sparnas, su pašaipa ir panieka, kritiškai žiūrèjo ị savivaldos pareigūnų pastangas mobilizuoti Lietuvos vyrus. Jo šaltinių vertinimu, Marijampolès aps. viršininkas (V. Goštautas -R.Z), surinkęs apskrities inteligentus, pasake agitacinę kalbą ir ịpareigojo juos vykti ị kaimus agituoti. Iš anksto parengtas agitacines kalbas vokiečiai "išrecenzavo". Nuvykę i organizuotus valsčiuose susirinkimus inteligentai aiškino žmonėms, kad agitatoriais tapo per prievartą, po to tas kalbas perskaitydavo. Savaime suprantama, kad tokia agitacija nebuvo veiksminga, po jos stojimas i batalionus nedaug pagerèdavo. Vokiečiai ir pats apskrities viršininkas apkaltino Marijampolès aps. inteligentus nevykusia agitacija.

Pogrindžio laikraštis "Laisvès kovotojas" Panevėžio apskrities viršininko plk. A. Gaušo aktyvius agitacinius veiksmus apibūdino kaip "neišmanėlio ir išgamos vapaliojimus" ir išreiške viltị, kad lietuviai karininkai, sutikę vadovauti formuojamiems "šešiems darbo batalionams", liks

66 Ten pat, 1. 70 .

67 Ten pat, 1. 96.

68 Laisvés kovotojas. 1943, birželio 15, Nr. 11, p. 2; 1943, kovo 17, Nr. 6, p. 2. 
"kapitonais be laivụ"68. Iš kai kurių faktų galima daryti prielaidą, jog nacionalinis antinacinis pogrindis prieš pernelyg aktyvius vokiškų mobilizacijų šalininkus netgi émèsi teroro aktų, jiems pritare ar bent gąsdino tokių veiksmų galimybe. Tame pačiame pogrindžio laikraštyje "Laisvejs kovotojas" 1943 m. gegužès pabaigoje buvo paskelbta informacija, jog 1943 m. gegužès 26 d. "nežinomų asmenų" buvo nušautas Vandžiogalos (Kauno aps.) policijos nuovados viršininkas, "pasižymèjęs jaunuolių gaudymu ir persistengimu vykdant kitus Kubiliūno ịsakymus"69.

"Savivaldos" ịvairių grandžių organizacinès, represinès, agitacinès priemonès, pastangos žūtbūt ịvykdyti Lietuvos vyrų registraciją, suformuoti statybos batalionus, atlikti tai, ko nepavyko padaryti patiems vokiečiams mèginant organizuoti SS legioną, buvo ryškūs jos kolaboravimo su vokiečiu okupantais veiksmai. Ir vis dèlto jie nesusiliejo ị vientisą procesą, savivaldos pareigūnų veiksmuose buvo daugiau aktyvios veiklos imitavimo negu realaus ir nuoširdaus darbo, buvo ịsiklausoma ị visuomenès ir pogrindžio nuostatas.

Galima tvirtinti, kad daugelis savivaldos pareigūnų prisidëjo prie vokiečių mobilizacinių planų Lietuvoje sužlugdymo. Pogrindžio šaltinių tvirtinimu, net plk. A.Gaušas, visuomenès ir net savo bendradarbių nuolat puolamas, buvo priverstas pasižadèti liautis agituoti. Kai vokiečiai griebdavosi represijų, tarp nukentèjusiųjų būdavo nemažai savivaldos pareigūnų, apkaltintų padéjimu Lietuvos vyrams išvengti mobilizacijų, dalyvavimu "šnibždančioje propagandoje". Antinacinio pogrindžio duomenimis (jie gali būti ir ne visai tikslūs), buvo suimtas Alytaus burmistras Pr. Matulionis, Vilniaus policijos valdininkas J. Balčaitis, Plokščiu (Šakių aps.) viršaitis Astrauskas, daugelis įvairias pareigas ejjusių karininkų.

Net ir sovietinio pogrindžio Lietuvoje šaltiniuose nemažai faktų apie tai, kad slapstytis nuo mobilizacijų dažnai padėdavo "lietuviška administracija ir policija", juose daryta išvada, jog Lietuvos kaimuose 1943 m. daugejo dezertyravusių su ginklais iš vokiečiu armijos, policija jų nepersekiojo. Apsimetus dezertyru neva buvo galima ginkluotam vaikščioti po visą Lietuvą. "Savivaldos" pareigūnų tokios veiklos reikšminga sritis buvo informacijos apie gresiančias gaudynes ir kitas represines priemones suteikimas, pagalba padedant papirkti vokiečius ir kt. Pogrindžio šaltinio duomenimis, $1943 \mathrm{~m}$. pavasarị vermachto atstovas Biržų aps. mobilizacijos štabe vokietis pulkininkas "nuolat ir gausiai" lietuvių vaišina-

${ }^{69}$ Ten pat. 1943, gegužès 30, Nr. 10, p. 2. 
mas daręs pareiškimus, jog vokiečių kariuomenei "esąs interesas” lietuvių paimti "kuo mažiausiai”. Vokiečių civilinès valdžios atstovai laikėsi nuošaliai ir piktinosi pulkininku, neva jis savo laikysena "niekinęs vokiškumą" vietinių gyventojų akivaizdoje. Būdavo atvejų, kai vyrų šaukimo komisijos vienoje ar kitoje vietoveje nepasirodydavo, nors šaukiamųjų ir būdavo gausiai atvykę.

Kalbant konkrečiai apie lietuvių statybos batalionų formavimo aplinkybes, iš pateiktų faktų matyti, jog jų atžvilgiu lietuvių pogrindžio jègų pozicija nebuvo visiškai vienoda. "Nepriklausoma Lietuva" ir "Laisvès kovotojas" palaikè "bekompromisę rezistencinę liniją" ir be išlygu laikèsi neigiamo nusistatymo, tuo tarpu "I laisvę" laikèsi nuosaikesnès, ne tokios kategoriškos pozicijos. Šio pogrindžio laikraščio 1943 m. gegužès 5 d. numeryje straipsnyje "Kaip eina mobilizacija?" buvo rašoma: "Véžlio žingsniu. 1919-1924 m. gimusieji lieka ištikimi savo pirmajam apsisprendimui - stoti, kai šauks nepriklausomos Lietuvos vyriausybe். I suẻmimo punktus per dieną atvyksta tik po vieną kitą. Miestiečių stoja daugiau negu kaimiečių [...] Dauguma stojančiųjų renkasi gen. Justo statybos batalionus. Gal ligi vasaros vokiečiams pavyks išvežti koki trejetą tūkstančių". Šią laikraščio informaciją galime vertinti ir kaip savotišką rekomendaciją bei jaunimo orientaciją, kaip elgtis vokiečiu ir lietuvių "savivaldos" mobilizacinių pastangų atžvilgiu.

Agitacija prieš statybos batalionus ir kitas mobilizacines akcijas antinacinio pogrindžio vesta ne tik pogrindžio spaudoje, bet ir žodžiu (vokiečiai ją vadino "šnibždančia propaganda"), atskirais ranka rašytais lapeliais, kurie operatyviai pasirodydavo vienoje ar kitoje vietoveje paskelbus registraciją. Tokios kategoriškai neigiamos nuostatos ir agitacijos pavyzdys gali būti archyvuose išlikęs lapelis:

"Kolegos,

"Savivaldos" dalintojai pradeda vergų medžioklę. Policija šiandien [1943]. V. 9 gavo telefonogramas apstoti visus kelius iš miesto ị provinciją ir dokumentus tikrinant gaudyti jaunus vyrus.

Kolegos, bėgdami nuo žvėrių venkit didžiųjų kelių. Bẻkit laukais ir nedideliais takeliais. Patogiausias laikas - anksti rytą. Sargybos ypač sustiprintos pavakariais.

Tèvynès frontas"70.

${ }^{70} L V O A$, f. 3377 , ap. 58 , b. $174,1.37$. 
Kokia buvo sovietinio pogrindžio Lietuvoje pozicija statybos batalionų formavimo atžvilgiu? Kai 1943 m. pavasari Maskva pasiekè žinios apie kuriamus batalionus, LKP(b) CK sekretorius ir LPJŠ viršininkas A. Sniečkus kẻlẻ sovietinio pogrindžio vadovams Lietuvoje uždavinị priešintis mobilizacijoms i armiją, i statybos batalionus, "statybos batalionuose ir dar gi reguliarioje armijoje" turèti savo žmonių ir dirbti "pakrikdymo" darbą iš vidaus, o fronto sąlygomis - organizuoti perẻjimą i Raudonosios armijos pusę. Tačiau $1943 \mathrm{~m}$. pavasarị ir vasarą sovietinis pogrindis Lietuvoje ir jo poveikio priemonès dar buvo silpnos. Tai labai gerai suprato ir A. Sniečkus, keldamas ardomojo darbo uždavinius: "ne perdaug mes stiprūs, nedideli mūsų ryšiai su masemis"

Sovietinio pogrindžio agentūros surinkta informacija apie statybos batalionus buvo labai netiksli ir be reikalo gąsdino Maskvą. Jos duomenimis, $1943 \mathrm{~m}$. Lietuvoje suformuoti ir pasiųsti i rytų frontą 10 statybos batalionų ( 3 iš Vilniaus, 2 iš Kauno ir 5 iš Panevéžio ${ }^{72}$.

1943 m. sudetingomis sąlygomis, kai net antinacinio pogrindžio jègos neturèjo vienodo nusistatymo, reikšmingas vaidmuo, orientuojant jaunimą, priklausė Lietuvos karininkijai. Nors kai kurie karininkai aktyviai rẻmé siekius steigti net ir SS legioną, apskritai Lietuvos karininkija neigiamai žiūrẻjo ị statybos batalionų ir kitų lietuviškų karinių formuočiu steigimą. Prieš jų kūrimą visą okupacijos laikotarpi aktyviai veikè Lietuvos Laisvès armija (LLA), Lietuvos kariuomenès atkūrimo perspektyvą siejusi su būtinumu išsaugoti Lietuvos jaunimą ir pogrindinių kariniu formuočiu kūrimu. Lietuvos kariuomenès karininkas Digrys ir kiti 1943 m. Ariogalos apylinkėse pogrindyje atkūrẻ šaulių organizaciją, pasivadinusią "Laisvés šauliais", i jos veiklą ịtraukẻ apie 200 žmonių, tarp jų ir kpt. J. Žemaitị (vieną iš pokario antisovietinès ginkluotosios rezistencijos Lietuvoje vadų). "Laisvès šaulių" pogrindinès veiklos svarbiausia sritis $1943 \mathrm{~m}$. buvo propaganda prieš mobilizaciją i statybos batalionus ir žmonių vežimą darbams ị Vokietiją

Kokie buvo vokiečių okupantų mobilizacinių užmojų ir okupuotos

\footnotetext{
${ }^{71}$ Sniečkaus A. 1943. 04. 11 laiškas M. Šumauskui, G. Zimanui ir kitiems. Ten pat, f. 1771, ap. 6, b. 35, 1. 10.

${ }^{72}$ LPJŠ 1943. 1123 žvalgybos duomenų santrauka Nr. 15. Ten pat, f. 1, ap. 1, b. 22, 1. 138; b. 27, 1. 36.

${ }^{73}$ Zaskevičiaus St. 1945. 12. 24 parodymai. Ten pat, f. 3377 , ap. 55, b. 33, 1. 32-32.
} 
Lietuvos visuomenès pasipriešinimo joms ịvairių veiksnių sąlygotos sudètingos ir prieštaringos situacijos, skelbtų mobilizacijų rezultatai Lietuvoje 1943 m. pavasarị ir vasarą? Užsiregistravusiųjų procentas atskiruose Lietuvos rajonuose buvo labai nevienodas, net ir vienos apskrities valsčiuose svyravo nuo 10 iki 80. Pogrindžio šaltinių duomenimis, mažiausiai vyrų registravosi Suvalkijoje ir Žemaitijoje, daugiausia - Panevežio, Zarasų, Utenos, Rokiškio, iš dalies Biržu apskrityse (ten užsiregistravo 50-80 proc. vyrų).

Biržų aps. iki $1943 \mathrm{~m}$. birželio 13 d. užsiregistravo per 2500 vyrų. Iš jų į statybos batalionus buvo paimta 160, i savisaugos dalinius ir vermachtą - maždaug po 30 asmenų. Vẻliau iš Biržų papildomai paimta 15 batsiuviu darbams vermachto daliniuose ir kitų asmenų, iš viso apie 30 žmonių. Biržų aps. užsiregistravo 149 Lietuvos kariuomenès karininkai, 150 puskarininkių.

Panevėžyje iki 1943 m. gegužès 30 d. užsiregistravo karininkų - 62, viršilų - 15, puskarininkių - 123, grandiniu - 26. Pogrindžio vertinimu, Panevėžyje bene stropiausiai vyko 1919-1924 m. gimusių vyrų ir karininkų registracija, iš viso užsiregistravo daugiau kaip 50 proc. vyrų ${ }^{74}$.

Didesnị registravimosi ir stojimo ị komisijas minètose Lietuvos apskrityse procentą galima aiškinti ịvairiomis aplinkybėmis: kai kurių apskričių lietuvių "savivaldos" pareigūnų aktyvia propagandine agitacine veikla (pvz., plk. A. Gaušo Panevėžio aps.), silpnesne pogrindžio įtaka, socialine ekonomine situacija ir visuomenès struktūra: mobilizacijų rezultatai buvo geresni, kur buvo daugiau nedidelių ūkių, kurių gausias šeimas jos lietẻ labiau. $1943 \mathrm{~m}$. gegužès $1 \mathrm{~d}$. potvarkiu buvo leidžiama ūkiuose palikti tokią darbo jëgą: iki 5 ha -1 darbingą asmeni, nuo 5 iki 10 ha -2 , nuo 10 iki $15-3$ ir t.t. ${ }^{75}$, galbūt gausesnių šeimų jaunimą labiau viliojo materialiniai stojimo motyvai (neblogas atlyginimas, socialinès privilegijos ir kt.).

1943 m. gegužès 19-30 d. Lietuvoje iš viso įsiregistravo 5667 vyrai, ịvairiems darbams ir karinei tarnybai buvo ịpareigoti - 1717 vyrų. Iki birželio $11 \mathrm{~d}$. Marijampolès aps. i statybos batalionus paimti 576 vyrai, Vilniuje iki balandžio 30 d. - 74 vyrai, i juos turejo būti paskirti ir užsirašę į SS legioną 25 asmenys $^{76}$.

\footnotetext{
${ }^{74}$ Lietuvių antinacinio pogrindžio šaltinio 1943.06. 30 pranešimas apie padètị Lietuvoje, LVOA, Dokumentų rinkinys Nr. 167, p. 17, 19, 29.

${ }^{75}$ Rakūnas A. Lietuvos liaudies kova prieš hitlerinę okupacija. Vilnius, 1970, p. 106.

${ }^{76}$ Bubnys A. Min. veik., p. 389-391.
} 
Antinacinio pogrindžio šaltinių duomenimis, 1943 m. gegužę-birželio pradžioje buvo suformuoti keturi lietuviu statybos batalionai, i Rytus išsiųsta apie 2 tūkst. Lietuvos vyrų, dar apie 500 pateko ị vermachtą ar savisaugos batalionus. $1943 \mathrm{~m}$. rugpjūčio pradžioje i Rytus išsiųstas dar vienas statybos batalionas. Taigi iš viso $1943 \mathrm{~m}$. į suformuotus lietuvių statybos batalionus pateko apie 2500-3000 vyrų.

Nuo 1943 m. vasaros Lietuvos gyventojai dažniausiai buvo imami talkininkauti karo ūkiui, vežami darbams ị Vokietiją, kur vykdant "totalinę mobilizaciją" reicho karo pramonei vis labiau trūko darbo rankų.

1943 m. mobilizacijụ rezultatus Lietuvoje vokiečiai vertino kaip "visais atžvilgiais nepatenkinamus": jų skaičiavimais, ị patikrinimą neatvyko apie 50000 šaukiamujų, gimusių 1919-1924 m., ir beveik tiek pat $1912-1918$ ir $1925 \mathrm{~m}^{77}$

Iš tikrųjų mobilizacijų rezultatai buvo katastrofiškai menki: vokiečiams ir lietuvių "savivaldai" iškilo didelių problemų iš šimtatūkstantinio Lietuvos vyrų rezervo, kurio dauguma, be jokios abejonès, tiko karo tarnybai, suorganizuoti vos kelių tūkstančių vyrų vermachto lietuviškus statybos dalinius. Tai akivaizdžiai byloja apie antivokiškas nuotaikas Lietuvoje ir požiūrị i Đokietijos kariaujamą karą.

Nereikia pamiršti, jog statybos batalionai formuoti specifinèmis 1943 m. sąlygomis, kurios skyrèsi tiek nuo $1941 \mathrm{~m}$. ir iš dalies $1942 \mathrm{~m}$., tiek nuo 1944 m. sąlygų Lietuvoje. Po 1940-1941 m. sovietmečio ịvykių, Lietuvos valstybę ir visuomenę ištikusios tragedijos ị Lietuvą įžengę vokiečiai sutikti su euforija, nes su Vokietijos karu prieš SSRS buvo siejamos Lietuvos nepriklausomybės atkūrimo viltys. Iš pradžiu vokiečiams nereikèjo dèti dideliu pastangų kuriant lietuviškas karines policines formuotes - savisaugos batalionus, atvirkščiai, iš esmès jų kūrimas ir karinis bendradarbiavimas su lietuviais buvo ribojamas. Nepasitvirtinę nacionaliniai lūkesčiai, įvestas okupacinis režimas, represijos po SS legiono boikoto, karinẻ katastrofa prie Stalingrado prablaivė net ir labai karštas, palankiai vokiečiu atžvilgiu nusiteikusias galvas. Ryškejjo ir stiprèjo įsitikinimas, jog Vokietija karą pralaimès ir bendradarbiavimas su ja, siekiant Lietuvos valstybingumo, neturi perspektyvos. Kita vertus, Vokietija dar nebuvo palaužta, dar toli nuo Lietuvos buvo frontas, Raudonoji armija, bolševizmo grèsmė, naujos sovietinès okupacijos pavojai ir kiti veiksniai, sudarę psichologini, emocini $1944 \mathrm{~m}$. kovos prieš bolševizmą, karinių dalinių Lietuvos teritorijai ginti kūrimo pagrindą ir kt.

${ }^{77}$ Lietuvos liaudis Didžiajame Tèvynès kare: Dokumentu rinkinys. Vilnius, 1982, p. 164. 


\section{Lietuvos vyrų keliai ị batalionus}

1943 m. situacija Lietuvoje lėmè iš esmès priverstinius asmeninius stojimo ị batalionus motyvus, tikrų savanorių buvo nedaug. Nenuostabu, jog priverstinius motyvus nurodo visi statybos batalionų kariai, savo noru perbėgę pas sovietų partizanus arba patekę ì jų ar Raudonosios armijos nelaisvę (tuo stengtasi pasiteisinti, sumažinti savo kaltę ir pan.). Antai panevėžietis A. Bitaitis savo parodymuose aiškino, jog jis buvo suimtas namuose nakti po to, kai keletą kartų šaukiamas neatvyko į komisiją. Jis buvo uždarytas ị kalëjimą, jame laikytas 6 paras. Kalëjimas buvo perpildytas sugautų vyrų, vienoje kameroje laikyta apie 50 žmonių. Atẻjęs vokietis komendantas klausė kalejjime uždarytų vyrų, ar jie jau "apsigalvoję" išvykti ị "darbus”. Kai sugauti vyrai duodavo sutikimą, jie būdavo išvežami, kalèjimas kiek ištuštėdavo, bet netrukus vėl pasipildydavo naujais suimtaisiais. Sutinkančiujų išvykti i darbus vokiečiai klausdavo, kur jie norị vykti - i darbus i Vokietiją ar ị statybos batalionus. Beveik visi pasirinkdavo statybos batalionus, nes "Vokietijos visi labai bijoję". Paimtieji i batalionus turèjo pasirašyti (savanorio - Freiwillige - raštą R. Z.), jog stoja i juos savo noru ${ }^{78}$.

Biržietis A. Calka ị statybos batalionus buvo mobilizuotas $1943 \mathrm{~m}$. liepos mėnesį. Gavęs du šaukimus atvykti ị mobilizacijos komisiją, i ją neatvyko ir buvo suimtas naktị latvių policininkų, su grupe suimtųjų nuvežtas ị Panevėží. Ten apskrities komisijoje jam taip pat leido pasirinkti, ar vykti i darbus i vokietiją, ar i statybos batalionus. A. Calka pasirinko tarnybą statybos batalione ${ }^{79}$.

Pasvalietis A. Ogintas, $1943 \mathrm{~m}$. balandžio mėnesị gavęs šaukimą registruotis, pradejjo slapstytis. Jo tvirtinimu, $1943 \mathrm{~m}$. pavasarị, paskelbus mobilizaciją i "darbo tarnybą", išsibėgiojo ir slapstèsi Pasvalio gimnazijos 6-8-ų klasių moksleiviai, slapstytis jiems padèjo vietos gyventojai. A. Ogintas policijos buvo suimtas $1943 \mathrm{~m}$. rugpjūčio 15 d. ir nugabentas į Panevèžio kalejjimą. Po savaitès pasirašè sutikimą stoti į "darbo batalioną" ir netrukus nugabentas i 5-aji statybos batalioną ${ }^{80}$.

\footnotetext{
${ }^{78}$ Bitaičio A. 1944. 05. 15 parodymai. $L V O A$, f. 1 , ap. 1 , b. $99,1.58-59$.

${ }^{79}$ Calkos A. parodymai 1944 m. Ten pat, 1. 86.

${ }^{80}$ Oginto A. 1944. 06. 14 parodymai. Ten pat, f. 1, ap. 1, b. 99, 1. 40-41; b. 100, 1. 2; Ogintas A. Mano prisiminimai iš partizaninio gyvenimo, 1944. 06. 14 Ten pat, f. 3377, ap. 3377, b. 813, 1. 1 .
} 
Panašus buvo ir Lietuvos vyrų kelias ị vokiečių priešlėktuvinès gynybos dalinius. Kaunietis V. Čižinauskas, vokiečių mobilizuotas $1943 \mathrm{~m}$. rugpjūčio 21 d., išvežtas ị Pskovą ir su 60 lietuvių grupe paskirtas ị vokiečiu priešléktuvinès gynybos dalinius. Jo tvirtinimu, 1943 m. birželio mènesị Šančių kareivinèse buvo uždaryta apie 100 žmonių, kurie atsisakẻ pasirašyti, jog ị vokiečių kariuomenę stoja savanoriais. Jie saugoti stiprios sargybos, sudarytos iš austrų, kurie, nepaisydami vokiečių draudimo, leisdavo perduoti suimtiesiems laiškus ir maisto. Išvežant iš Kauno, juos rengèsi išlaisvinti lietuvių savisaugos bataliono kariai, bet vokiečiai stipriai saugoję traukinį ${ }^{81}$.

Br. Bagdonavičius, Vievio aps. Lapaikos kaimo gyventojas, nuvykęs ị Kaišiadoris buvo suimtas, nuvežtas į Vilnių ir apgyvendintas Artilerijos kareivinèse. Per savaitę ten surinkta apie 170 lietuvių, jie išvežti i Pskovą ir nedidelėmis grupelèmis (po 4-5 žmones) išskirstyti priešlèktuvinio dalinio padaliniuose ${ }^{82}$.

Statybos batalionuose buvo asmenų, kuriems grèsė bausmės už įvykdytus smulkius nusikaltimus (spekuliaciją, konfliktus su policija ir pan.), sugautų vyrų, pabėgusių iš darbų Vokietijoje, dezertyravusių iš savisaugos batalionų karių. Juose buvo žmonių, susikompromitavusių bendradarbiavimu su sovietu valdžia 1940-1941 m., tarnyba batalionuose jiems buvo savotiška bausmè ir būdas išvengti vokiečių ir lietuvių policijos represijų ${ }^{83}$.

Pažymėtina, jog vienu metu formuojant statybos batalionus, mobilizuojant darbams ị reichą, i vermachto (priešléktuvinès gynybos ir pan.) dalinius, daug prievarta surinktų Lietuvos vyrų, turẻjusių galimybę pasirinkti, į statybos batalionus stojo kaip ị nacionalinę, lietuvišką karinę formuotę, tarnybą juose rinkosi kaip geriausią išeitị iš "kelių blogybiụ". Bijota ne tik išvežimo ị Vokietiją, bet ir tarnybos grynai vokiškuose daliniuose. Antai Pr. Nagys savo atsiminimuose rašo: "Man terūpejjo, kad paskirtu i lietuvišką dalinị, o ne kur priešlẻktuvinèje apsaugoje prie patrankų su vokiečiais. Ten jau daug lietuvių buvo patekę"»4.

\footnotetext{
${ }^{81}$ Čižinausko V. 1944. 05. 17 parodymai. Ten pat, f. 1, ap. 1, b. 99, 1. 56.

${ }^{82}$ Bagdonavičiaus Br. 1944. 05. 18 parodymai. Ten pat, 1. 64.

${ }^{83}$ Antai statybos bataliono karys B. Petrauskas (g. 1914 m.) 1940-1941 m. buvo kandidatas i kompartijos narius, Lazdijų aps. sovietinès žemès komisijos pirmininkas. Ten pat, f. 1771, ap. 10, b. 204, 1. 59.

${ }^{84}$ Nagys Pr., min. veik., p. 60.
} 
Tyrinètuose šaltiniuose nepavyko aptikti užfiksuotu aiškių tikrai savanoriško stojimo į batalionus atvejų, patriotinių, idealistinių motyvų, nors, be abejo, jų būta. Propagandinès agitacinès batalionų formavimo akcijos metu buvo daug apeliavimų i patriotinius jausmus, be jau minėtų, oficialioje spaudoje skelbti šūkiai: "Kas stoja ị lietuvių statybos batalionus, prisideda prie kovos už savo tèvynès laisvę", "Statybos batalionai savo darbu padès vermachtui apsaugoti lietuvių tautos gyvybę", "Lietuvių statybos batalione Tu taip pat gali kovoti už savo tèvynès laisvę" Batalionuose, be abejo, būta žmonių, patikejjusių tokia propaganda, įsivaizdavusių, jog tarnyba batalionuose bus pareigos atlikimas "tautai ir tévynei", "kerštas bolševikams", kovą už lietuvių tautos politinius, valstybinius siekius sutapatinusių su Vokietijos karu prieš SSRS, pagaliau provokiškai nusiteikusių žmonių: kaip minèta, ị statybos batalionus buvo pasiųsti vyrai, užsirašę ị nesuformuotą SS lietuvių legioną.

Tikrieji patriotiniai motyvai, suprastas kovos už Vokietijos interesus beprasmiškumas, miglota galimybe tapti Lietuvos kariais daugeliui žmonių buvo ne stojimo, o vengimo tarnauti motyvai. Lietuvių savisaugos batalionų karo kapelionas Z. Ignonis (Ignatavičius) savo karo metų atsiminimuose rašé, jog "vokiečiai labai stengėsi pravesti jaunų vyrų mobilizaciją i vadinamus "statybos batalionus", tik niekas nestojo, visi kèlé klausimą: kokia iš to nauda Lietuvai?" Klausimas, jo nuomone, buvęs "pilnai pagrịstas: Lietuva nesutinka vergauti ir badauti. Lietuva nori vèl būti laisva ir nepriklausoma"

Buvęs 2-ojo statybos bataliono karys Pr. Nagys savo tarnybą batalione vadina tarnyba "priverstinejje kariuomenejje", jos prasmę nusako tokiais žodžiais: “... rūpinausi, kad mano kareiviai ir aš nepakliūtume i kokias pinkles, iš kurių negalètume ištrūkti. Visada maniau, kad už reichą mes nekariausime. Mes esame čia, kad nebūtume už grotų, kad liktume gyvi. Vyrų jau daug sẻdėjo uždarytų. Daugelio jų likimas dar ir šiandien liko nežinomas"

Tarp kitų stojimo ị batalionus motyvu paminètini ir materialiniai, nelengvomis karo ir vokiečių okupacijos sąlygomis, matyt, vaidinę tam tikrą vaidmenị. Eiliniai kareiviai gaudavo 37,5-52 rm atlygi-

\footnotetext{
${ }^{85}$ Ateitis. 1943, balandžio 10, p. 1; balandžio 12, p. 1; Karys. 1943, balandžio 3, Nr. 14, p. 6. ${ }^{86}$ Ignonis Z. Praeitis kalba: Dienoraštiniai užrašai, Gudija 1941-1944. Brooklyn, N. Y, 1980, p. $159-160$.

${ }^{87}$ Nagys Pr. Min. veik., p. 67. 
nimą per ménesi (jis mokètas kas dešimt dienų), apie $100 \mathrm{rm}$ mokèta šeimoms išlaikyti, jos naudojosi îvairiomis socialinėmis (pvz., medicinos paslaugų) lengvatomis ir kt. ${ }^{88}$

Vokiečiai viliojo ị karinę tarnybą $1943 \mathrm{~m}$. vasario mėnesi paskelbta turto reprivatizacija, pabrèždami, jog joje galès dalyvauti tik tie asmenys, kurie patys ar jų šeimų nariai prisidès prie kovos su bolševizmu. Plk. A. Birontas, 1944 m. pradžioje lankydamasis statybos batalionuose, pažymėjo, jog "Tèvynè laikys juos pirmaisiais savanoriais ir visom išgalėm ateityje sudarys jiems tinkamas gyvenimo sąlygas" 89 .

Taigi statybos batalionų formavimo aplinkybès lėmé gana margą, ịvairią jų sudètį. Batalionuose buvo kadrinių, nusipelniusių, išsilavinusių Lietuvos kariuomenès karininkų. Antai 1-ojo statybos bataliono vadas plk. ltn. K. Pranckonis buvo 1919 m. Lietuvos kariuomenès savanoris, Nepriklausomybės kovų dalyvis, 1933 m. baigęs Vytauto Didžiojo karo mokyklą, vẻliau, 1944 m., jis tarnavo Lietuvos vietinès rinktinès štabe ${ }^{90}$. Galima manyti, jog karinè tarnyba vermachto daliniuose daugeliui Lietuvos karininkų buvo priimtinesnè negu, ypač iš pradžių, daugiausia policines funkcijas vykdžiusiuose savisaugos batalionuose. Tuo galima paaiškinti faktą, kad statybos batalionuose santykiškai buvo daugiau aukštesnio laipsnio buvusių Lietuvos kariuomenès karininkų. Antra vertus, statybos batalionuose tarnavo nemažai kadrinių Lietuvos kariuomenès karininkų, savo laiku atleistų iš karinès tarnybos dažnai už įvairius nusižengimus. Finansų generalinis tarèjas J. Matulionis savo atsiminimuose tvirtina, kad vokiečiai ị statybos batalionus neprièmé 8 karininkų, kurie kaltinti girtavimu ir nedrausmingumu ${ }^{91}$.

Statybos batalionuose buvo daug ịvairių karinių specialybių atsargos karininkų. Antai 1-ojo statybos bataliono kuopos vadas leitenantas Antanas Natkevičius 1929 m. buvo baigęs Lietuvos karo mokyklos karinę aspirantūrą (atsargos karininkų), inžinerijos specialybę, o 1943 m. pavasarị Kaune ịstojo ị organizuojamą statybos batalioną.

Nors, kaip minèta, vokiečių generolas E. Justas 1943 m. kovo mèn. lietuvių inžinerijos (statybos) batalionuose pageidavo matyti "sveikus ir stiprius vidutinio amžiaus vyrus”, i juos pateko daug jaunų, pirmąkart

\footnotetext{
${ }^{88}$ Oginto A. 1944 m. parodymai. LVOA, f. 1, ap. 1, b. 99, 1. 43; Ateitis. 1943, kovo 23, Nr. 68, p. 1.

${ }^{89}$ Plk. Birontas aplankè lietuvių statybos batalionus. Ateitis. 1944, vasario 7, Nr. 31, p. 2.

${ }^{90}$ Lietuviu enciklopedija, t. 23, p. 439-440.

${ }^{91}$ Matulionis J. min. veik., p.278.
} 
aprengtų kareiviška uniforma, visiškai kariško gyvenimo ir tvarkos nepažinojusių, kariškai nemokytų, prievarta sugaudytų ir surinktų šaukiamojo amžiaus ir dar jaunesnių jaunuolių, tapusių savotiškais "rekrutais", vokiečių ir lietuvių "savivaldos" propagandos suviliotų, galbūt troškusių patirti karinių nuotykių kovoje "prieš bolševizmą" Rytuose. Antai Tauragés ortskomendantūra 1944 m. vasario mèn. Panevėžio ortskomendantūrai pasiuntè du 14 ir 15 metų amžiaus savanorius. Pastaroji atsisakè juos priimti ir prašè "tokių jaunuolių" nesiųsti. Keturiolikmetis tauragiškis jau anksčiau buvo atvykęs i Panevèži stoti ị statybos batalioną ${ }^{92}$.

1-ajame statybos batalione tarnavo šio bataliono vado K. Pranckevičiaus-Pranckonio šešiolikmetis (g.1927 m.) sūnus Antanas Pranckevičius $^{93}$.

Savaime suprantama, jog dažniausiai prievartiniais metodais, paskubomis suformuoti ir pasiųsti į Rytus statybos batalionai iš pat pradžiu nebuvo ir negalejo būti drausmingi kariniai vienetai. Jau iš batalionų formavimo vietų prasidèjo dezertyravimas, kuris tęsèsi vykstant ì pafrontę ir batalionų dislokacijos vietose.

Sovietinio pogrindžio Lietuvoje šaltiniuose netgi tvirtinta, jog vieno Panevėžyje suformuoto statybos bataliono vokiečiams nepavyko išsiųsti i rytus: iš jo dezertyravo 530 iš 600 , telikę apie 60 vyrų. Lietuvis karininkas liepęs bẻgti net ir nenorejjusiems dezertyruoti kariams ${ }^{94}$.

Sovietiniai šaltiniai nepatikimi, juose duomenys apie dezertyravimo mastą išpūsti, tačiau apie masinị dezertyravimą iš statybos batalionų byloja ir lietuvių pogrindžio šaltiniai: iš dviejų Panevėžyje suformuotų batalionų (matyt, 2-ojo ir 4-ojo) dezertyrų buvo "gana gausu", iš 1943 m. gegužès 14 d. išsiunčiamo bataliono (2-ojo - R. Z.) pabėgo per 200 vyrų ${ }^{95}$.

Viename iš šio pogrindžio šaltinių aprašytas konkretus nesèkmingo bandymo dezertyruoti atvejis. 1943 m. rugsejjo 17 d. vakare Rokiškio geležinkelio stotyje sustojus traukiniui, kuriuo iš Panevėžio i Pleskovą (Pskovą - R. Z.) vyko 5-ojo statybos bataliono apie 80 karių,

${ }^{92}$ Panevėžio ortskomendantūros 1944.02 .10 raštas Tauragès ortskomendantūrai, $L C V A$, f. R1476, ap.1, b.137, 1.. 96.

${ }^{93}$ LYA, f. K-1, ap.58, b.42013/3, 1. 413-414.

${ }^{94}$ Lietuvos komunistu partijos apybraiža (1940-1959). Vilnius, 1985, t. 3, p. 161; Apie įvykius Lietuvoje. $L V O A$, f. 1, ap. 1, b. 3, 1. 1; Macevičiaus J. (Žaibo) 1944 m. laiškas A. Sniečkui. Ten pat, b. 436, 1. 46.

${ }^{95}$ Nežinomas pogrindžio šaltinis. LVOA, Dokumentų rinkinys Nr. 167, p. 18, 29. 
išlipo 10 beginklių žmonių ir bandė pasišalinti. Juos apšaudẻ Rokiškio geležinkelio policijos vachmistras Bukauskas. Vienas karys - A. Vaškinèlis - nušautas, 8 pasidavė ir buvo atiduoti Rokiškio žandarmerijai, 1 pavyko pabėgti ${ }^{96}$. Kaip pažymèta šaltinyje, vachmistras Bukauskas dèl panašiu "aktyvių" veiksmų pogrindžio žmonių jau anksčiau buvo "stebimas".

Remiantis kai kuriais sovietiniais ir lietuvių pogrindžio šaltiniais, galima manyti, kad bent kai kuriais atvejais su dezertyravimu iš statybos batalionų galëjo būti susijusi ir kai kurių jų karininkų veikla. Siekdami gelbèti Lietuvos jaunimą nuo neaiškaus likimo rytuose, jie galẻjo būti net bėgimo iš batalionų iniciatoriai ${ }^{97}$.

Vokiečiai nebuvo patenkinti statybos batalionu formavimo eiga ir kitų mobilizacijų rezultatais. Kaip matyti iš įvairių faktų, nepasitenkinimą rodè ir pats batalionų "globėjas" gen. mjr. E. Justas. Minètuose 1946 m. parodymuose jis užsimena apie antivokiškas nuotaikas, "aiškiai prasiveržusias" Lietuvoje 1943 m., kai norèta imtis "prievartinio šaukimo". E. Justas vokiečiu (kartu ir savo) nesėkmes aiškino paprastai ir paviršutinišskai, - "labai prasta civilinio valdymo politika", tačiau jis buvo teisus ir įžvalgus, teigdamas, kad "lietuviai vos galèjo nuslèpti savo piktdžiugą", nes jau seniai buvo pastebėję, jog neįmanoma kovoti už Lietuvos laisvę su vokiečiu pagalba ${ }^{98}$.

\section{Statybos batalionu suformavimas ir išsiuntimas i vokiečių Šiaurès fronto armijų užnugarị. Veiklos pobūdis.}

Kas buvo tie $1943 \mathrm{~m}$. pavasarị paskubomis formuojami ir siunčiami už Lietuvos ribų, į vokiečių Šiaurès fronto armijų užnugarị lietuviški kariniai daliniai, oficialiai vadinti lietuvių statybos (inžinerijos) batalionais, kuo jie buvo panašūs ar skyrèsi nuo sovietinių okupantų likviduotos Lietuvos kariuomenès pionierių batalionų, nuo jau veikusių lietuvių savisaugos batalionų, kokius savo veiklos pėdsakus paliko Rusijos žemëje ir kitur?

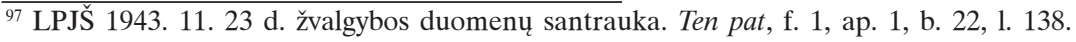

${ }^{98}$ Laisvés Kovu archyvas. Kaunas, 1993, t. 9, p. 149-150.
} 
Lietuvos kariuomenès pionieriu (vadintų "sapieriais", "sapiorais") ir inžinerijos daliniai pradèti kurti 1919 m. pradžioje. $1920 \mathrm{~m}$. vasario mèn. prie Generalinio štabo Susisiekimo dalies pradejjo veikti Armijos inžinierių valdyba (viršininkas mjr. L. Šilingas). Viena iš naujų formuočiu, kurią reikẻjo sudaryti inžinerijos valdybai, buvo inžinerijos batalionas, nes tuo metu veikè tik viena atskira "sapiorų" kuopa. Tačiau inžinerijos batalionui sudaryti trūko inžinerijos puskarininkiụ ir karininkų, ir jis nebuvo suformuotas ${ }^{99}$. Sistemingas pionieriu mokymas Lietuvos kariuomenèje prasidèjo nuo $1926 \mathrm{~m}$., tada sudarytos atskiros kariniu specialistų komandos: pionierių, sprogdintojų, dailidžių, kalvių. 1927 m. pabaigoje "sapieriai" atsiskirti nuo technikos pulko ir pavadinti pionieriu batalionu. Nuo $1935 \mathrm{~m}$. batalionas pavadintas 1-uoju inžinerijos batalionu, tačiau kasdieninejje kalboje jis ir toliau dažniausiai buvo vadinamas pionierių batalionu. $1935 \mathrm{~m}$. suformuotas 2-asis inžinerijos batalionas, péstininkų ir kavalerijos pulkuose suformuoti pionierių būriai, sudarę integralią tụ pulkų sudedamają dalị ${ }^{100}$.

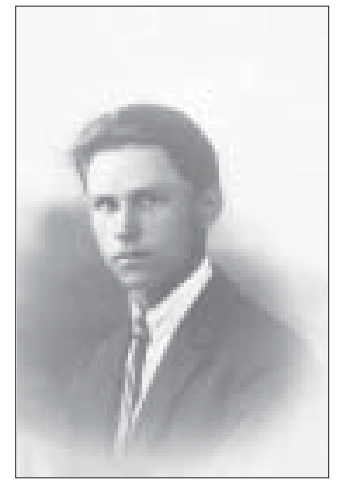

A. Natkevičius Marijampolès gimnazijos mokinys, $1926 \mathrm{~m}$.

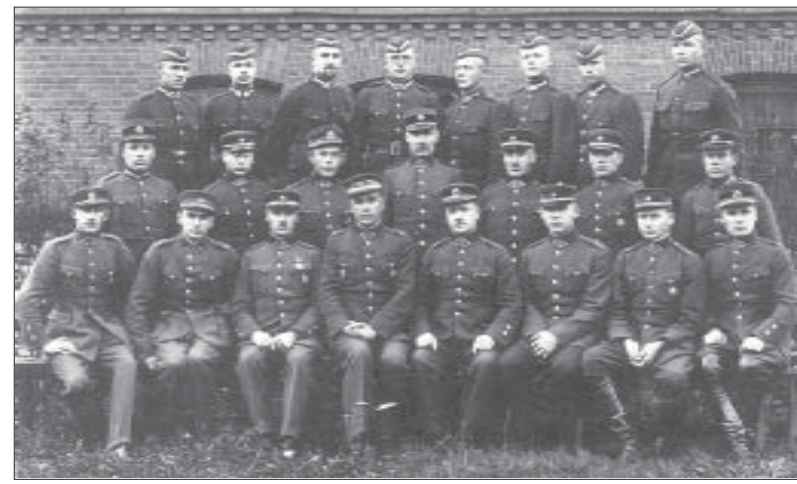

Lietuvos karo mokyklos karininkų ir kariūnų aspirantų grupe (apie 1927-1928 m.).

Paskutinèje eilèje antras iš dešinès A. Natkevičius

\footnotetext{
${ }_{99}$ Pionieriai. Lietuvių enciklopedija, t. 23, p.24; Autorius nenurpdytas/ Karo technikos štabo ir technikos dalių praeities bruožai. Karys, 1934, Nr.44, p. 900.

${ }^{100}$ Statkus V. Lietuvos ginkluotosios pajegos 1918-1940 m. Chicago, Illinois, 1986, p. 322.
} 


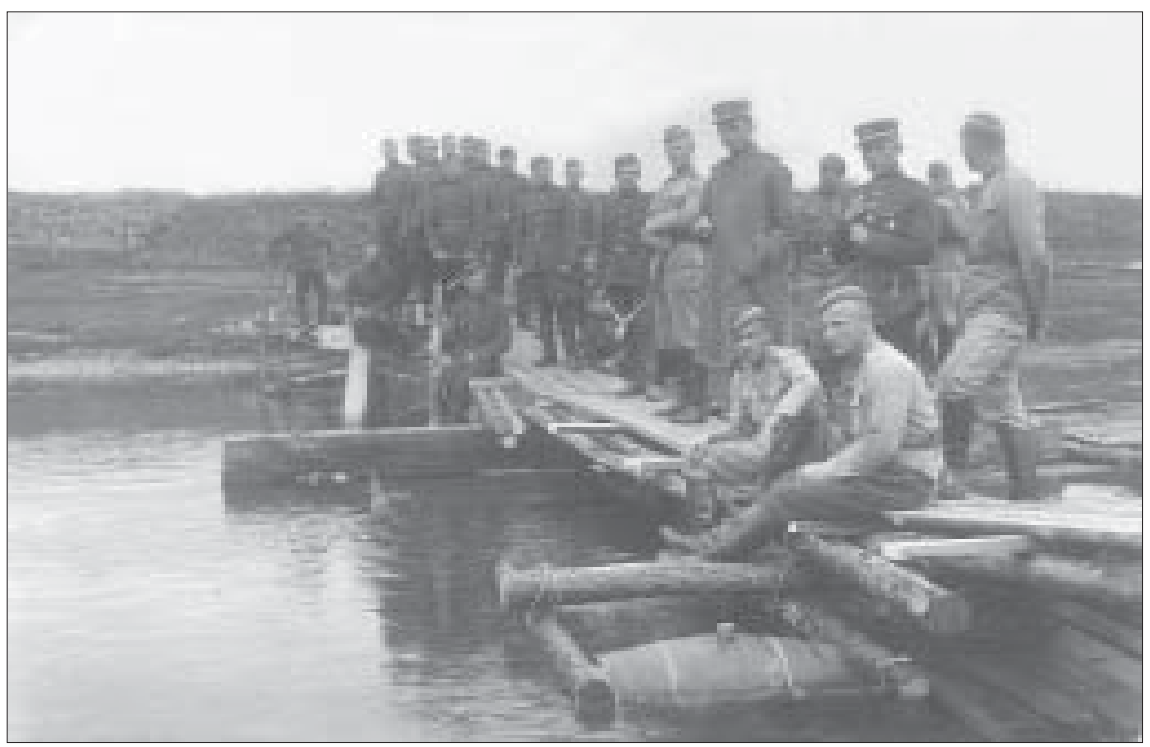

Pirmas iš dešinès A. Natkevičius
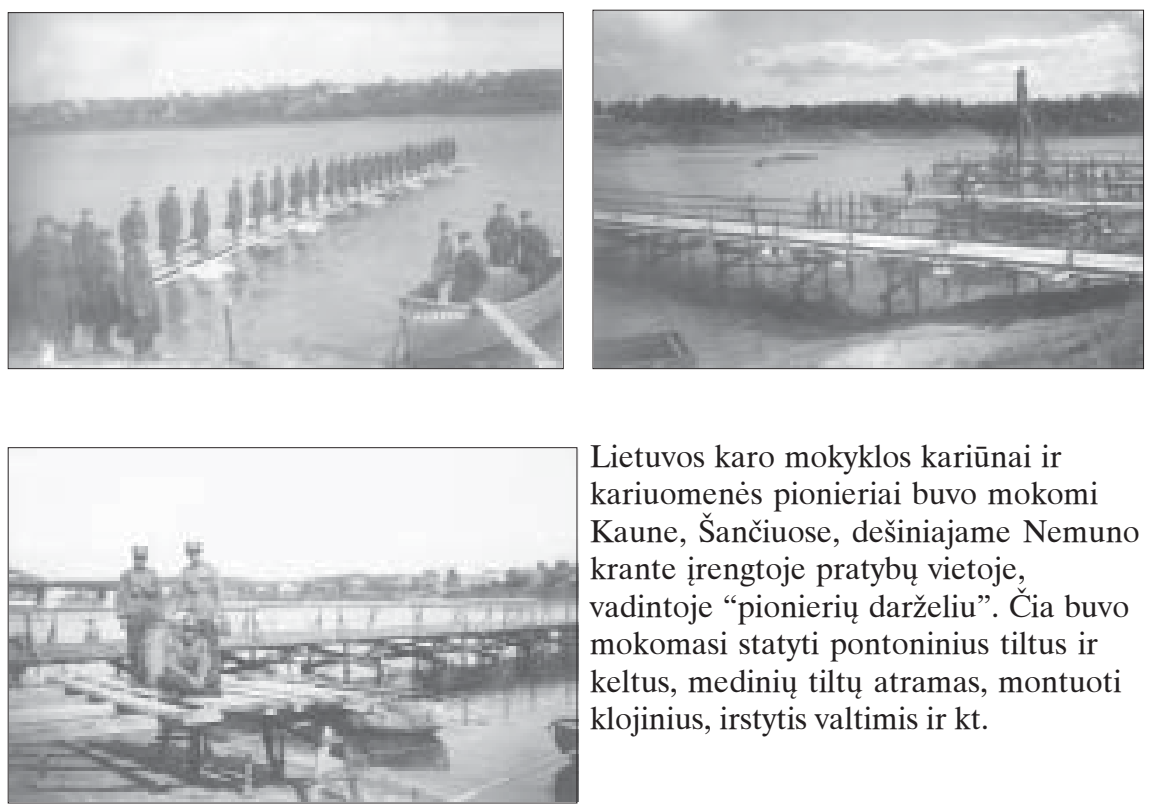

Lietuvos karo mokyklos kariūnai ir kariuomenès pionieriai buvo mokomi Kaune, Šančiuose, dešiniajame Nemuno krante įrengtoje pratybu vietoje, vadintoje "pionierių darželiu". Čia buvo mokomasi statyti pontoninius tiltus ir keltus, mediniu tiltų atramas, montuoti klojinius, irstytis valtimis ir kt. 

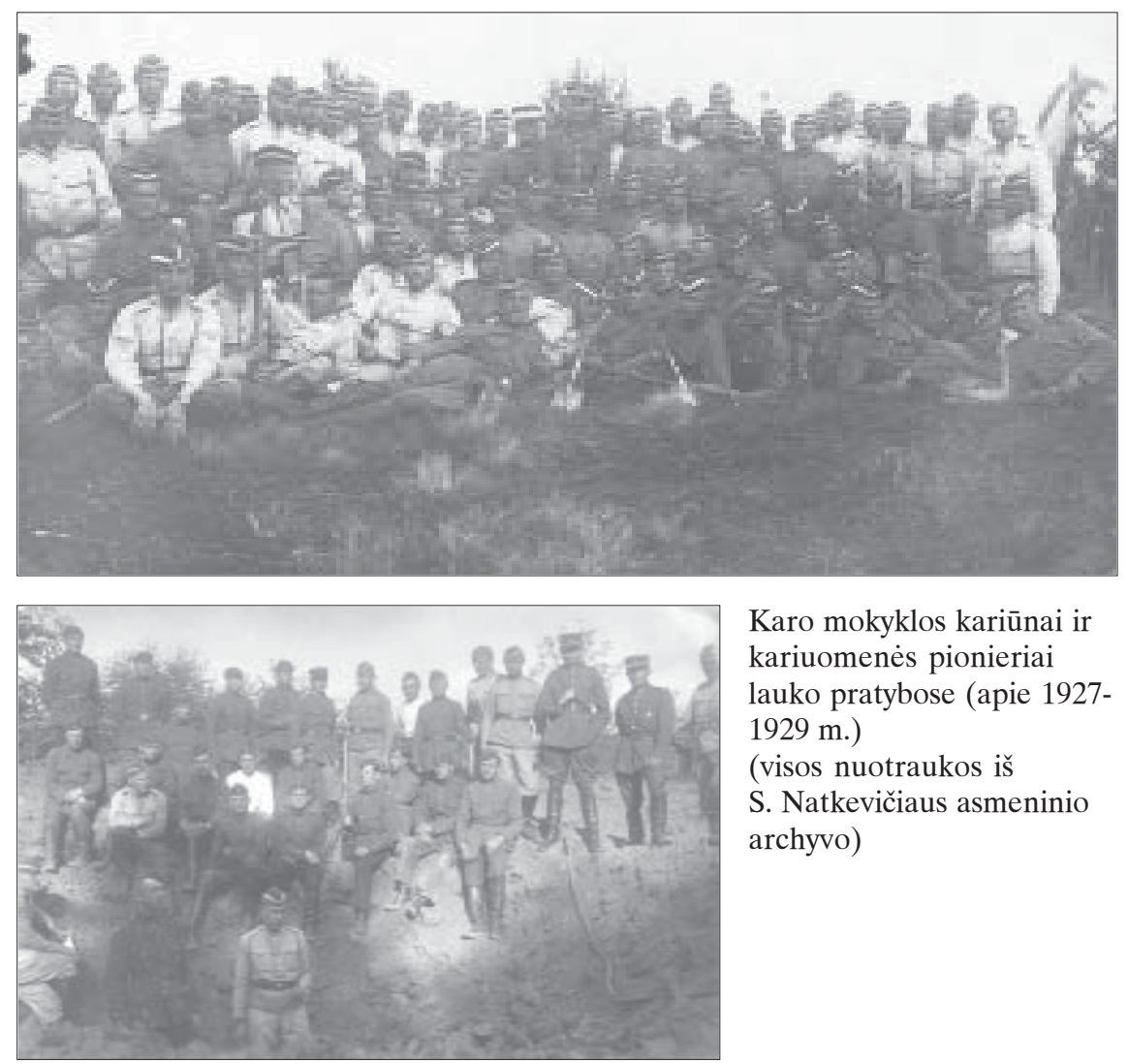

Karo mokyklos kariūnai ir kariuomenès pionieriai lauko pratybose (apie 19271929 m.)

(visos nuotraukos iš S. Natkevičiaus asmeninio archyvo)

Atsižvelgiant ị statybos (inžinerijos) batalionų formavimo ir komplektavimo 1943 m. aplinkybes, jų skubų išsiuntimą i Rytus ir kitas priežastis, galima daryti prielaidą, kad jie mažai kuo buvo panašūs ị buvusios Lietuvos kariuomenès pionierių batalionus ar vermachto pionierių dalinius. Kaip minėta, gen. E. Justas kvietė ị inžinerijos (statybos) batalionus "stiprius vidutinio amžiaus vyrus", tačiau jų mažai atsiliepè, o suformuotuose batalionuose atsidūre daug 1919-1924 m. ir vẻliau gimusių jaunuolių, kuriuos pirmiausiai ir liete skelbtos registracijos. İdomu pažymèti, kad 1943 m. pavasari juos formuojant iš pat pradžių kalbèta apie inžinerijos (statybos) batalionus, o vẻliau apie statybos (inžinerijos) batalionus. Matyt, žodžių sukeitimas vietomis nebuvo atsitiktinis ir labiau atspindèjo realią situaciją suformuotuose batalionuose. 
I suformuotus batalionus Lietuvos kariuomenèje inžinerijos (pionierių) daliniuose tarnavusių Lietuvos vyrų, matyt, pakliuvo nedaug. Statybos batalionų karininkų ir puskarininkiu sudètis pagal karines specialybes buvo labai ịvairi, juose buvo pėstininkų, kavaleristų, netgi aviatorių. J. Borevičiaus tvirtinimu, 5-ojo statybos bataliono 2-osios kuopos vadas buvo aviacijos vyr. ltn. lakūnas Albinas Molis ${ }^{101}$ ir kt.

Statybos batalionuose karinių inžinerijos specialistų funkcijas vietoj lietuvių karininkų atliko ir jų stygių kompensavo specialistai vokiečiai. A. Bitaičio tvirtinimu, kiekvienoje kuopoje buvo 6-7 vokiečiai, jie kuopose buvę tikrieji "šeimininkai", lietuviai karininkai vykdę jų nurodymus. Beveik tą patị liudijo ir A. Calka: 5-ajame statybos batalione buvo apie 30 vokiečiu, kuopose bent po 5 , kiti dirbo štabe. Vokiečiai isakinèdavo lietuviams karininkams, o šie tvarkydavo kareivius ${ }^{102}$.

Lietuvoje suformuoti batalionai, oficialiai vadinti statybos (inžinerijos) batalionais, bent iš pradžiu buvo paprastos darbo jẻgos, t.y. darbo, batalionai, tik vèliau išèję karini mokymą ir igiję patyrimo jie tapo kariniais statybos (inžinerijos) batalionais.

Lietuvių statybos batalionų suformavimo ir išsiuntimo ị vokiečių šiaurès fronto užnugarị eiga 1943 m. gegužès-rugpjūčio mėnesiais matyti iš lentelès:

\begin{tabular}{|c|l|l|l|}
\hline Batalionų Nr & Suformavimo vieta & Išykimo data & Vadai \\
\hline 1. & Kaunas & 1943 m. gegužés 5 d. & $\begin{array}{l}\text { gen. št. plk. Itn. } \\
\text { K. Pranckevi- } \\
\text { čius-Pranckonis }\end{array}$ \\
\hline 2. & Panevėžys & 1943 m. gegužés 14 d. & $\begin{array}{l}\text { plk. Itn. Vl. } \\
\text { Strimas-Strima- } \\
\text { vičius; kpt., } \\
\text { vèliau mjr. A. } \\
\text { Milaševičius }\end{array}$ \\
\hline 3. & Vilnius & 1943 m. birželio 2 d. & mjr. S. Narušis \\
\hline 4. & Panevėžys & 1943 m. birželio 8 d. & $\begin{array}{l}\text { mjr. Juozas Čer- } \\
\text { nius }\end{array}$ \\
\hline 5. & Panevėžys & 1943 m. rugpjūčio 4 d. & $\begin{array}{l}\text { mjr. St. Nagrod- } \\
\text { skis }\end{array}$ \\
\hline
\end{tabular}

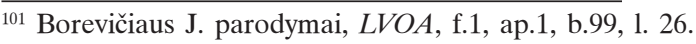

${ }^{102}$ LVOA, f.1, ap.1, b. 99, 1. 59; b.98, 1.87. 
Iš Lietuvos išsiųsti statybos batalionai, ypač paskutinieji, nebuvo sukomplektuoti iki galo. A. Oginto tvirtinimu, 5-ajame batalione buvo tik apie 250-300 karių, jame buvo 3 kuopos: 1-oji, 2-oji, 4-oji, o 3-ioji kuopa i Rytus atvyko vèliau, jos kariai išskirstyti po 1-ają ir 2-ają kuopas ${ }^{103}$. Kaip minèta, istoriografijoje yra tvirtinimų, jog $1943 \mathrm{~m}$. buvo suformuotas ir 6asis lietuvių statybos batalionas ${ }^{104}$. Yra duomenų, kad 6-asis batalionas iš tikrujų buvo formuojamas. Antai A. Calka savo parodymuose teige, jog jis buvo paskirtas i 6-ojo bataliono 4-ają kuopą. Bataliono vado pavardès nenurodè (neprisiminè), jis buvęs pulkininkas, iš Vokietijos grịžęs repatriantas. Išbuvęs batalione apie 3 savaites, A. Calka buvo perkeltas į 5-aji batalioną, nes jame nebuvo 3-iosios kuopos ${ }^{105}$.

Iki 1943 m. lapkričio pradžios 6-asis batalionas tikrai nesuformuotas. Gen. mjr. E. Justas, Prienuose sveikindamas naujai kuriamos karinès formuotès - "vietinès apsaugos" - būriu savanorius, pažymėjo, jog jau veikia penki statybos batalionai ir sudaromas šeštasis. Jis ragino stoti i statybos batalionus, nes jų darbas turịs "didžiausios reikšmės kovoje su bolševizmu" 106 . Tačiau duomenų apie galutini bataliono suformavimą ir jo išsiuntimą i pafrontę nepavyko aptikti, matyt, jis nebuvo suformuotas, formuojamo bataliono padaliniai išskirstyti po kitus batalionus ar keičiantis situacijai panaudoti kitais karo tikslais.

Visi 5 suformuoti statybos batalionai išsiųsti ị vokiečiu Šiaurès fronto armijų užnugarị dirbti įtvirtinimų statybos darbų Lugos, Narvos, Pskovo, Polocko, Breslavlio (Breslaujos), Daugpilio apylinkėse. Visi batalionai buvo pavaldūs vokiečiu kariuomenès Šiaurès fronto vadovybei ir vokiečių buvo atskirų pionierių dalinių štabų, kurių vadai buvo generolai, žinioje.

Kiekviename batalione buvo štabas, 4 kuopos -3 statybos ir 1 transporto (joje - apie 200 arklių), iš viso turëjo būti 600-700 vyrų, tačiau praktiškai tebuvo ne daugiau kaip po 400-500 vyrų: batalionai išvykdavo nevisiškai sukomplektuoti ir véliau būdavo papildomi, jų gretos praretédavo dél dezertyravimų iš formavimo vietų ir pakeliui i i paskirties vietas. Iš pradžių batalionų kariai nebuvo ginkluoti, kuopos turejo tik po 20 šautuvų sargybų tarnybai ir apsaugai. Vèliau pafrontèje, èmus stipriau veikti sovietiniams partizanams, apginkluoti lengvaisiais ginklais - šautuvais ir kulkosvaidžiais ${ }^{107}$. Statybos ba-

\footnotetext{
${ }^{104}$ Stankeras P., min. veik., p. 190.

${ }^{105}$ Calkos A. 1944. 05. 16 parodymai. $L V O A$, f. 1, ap. 1, b. 99, 1. 86.

${ }^{106}$ Gen. mjr. E. Justas aplankè vietinès apsaugos būrių savanorius. Karys. 1943, lapkrišio 6, Nr. 45 , p. 5 .
} 
talionų karių parodymuose minimi belgiški, rusiški šautuvai, karininkai buvo ginkluoti belgiškais pistoletais. Apranga - vokiška, su nacionaliniais skiriamaisiais ženklais - trispalviais skydeliais ant kairès rankovės ir užrašu "Lietuva"108 .

Visi statybos batalionai išlydèti iš Lietuvos pabrèžtinai iškilmingai, viešai, gausiai dalyvaujant visuomenei, išlydètuvès plačiai nušviestos oficialiojoje spaudoje. Apibendrintas jų vaizdas buvo toks: batalionų kariai būdavo išrikiuojami aikštėse priešais svastiką, veliavomis ir gėlèmis išpuoštas tribūnas, kuriose stovejo aukšti vokiečiu ir lietuvių "savivaldos" pareigūnai: pats gen. mjr. E. Justas arba jo atstovai, apygardų komisarai, apskričiu viršininkai, miestų burmistrai ir kt. Virš tribūnų plevėsavo Vokietijos reicho vẻliava ir lietuviška trispalvè (kaip rašè oficialioji spauda, vẻliavos turejo simbolizuoti vokiečių ir lietuvių "ginklo brolybę" ir bendrą kovą prieš bolševizmą), jomis buvo išpuošiamos ir miestų gatvès, namai. Buvo sakomos iškilmingos kalbos, atliekami Vokietijos ir Lietuvos himnai, tautiniais rūbais pasipuošusios lietuvaitès dalijo kariams gèles. Iškilmès baigiamos batalionų karių iškilmingu paradu. Išvykstančių su lietuviais kariais ị rytus traukinių vagonai būdavo išpuošiami ąžuolų vainikais ir kitokiais žalumynais. Tačiau statybos batalionų, išskyrus galbūt tik 1-ojo bataliono, kariai išlydèti nedavę karinès priesaikos, tai padarydavo nuvykę i savo veiklos rajonus ${ }^{109}$.

Išlydėdamas 4-ąji statybos batalioną Panevėžyje gen. mjr. E. Justas savo kalboje "ugningais žodžiais" kalbèjo apie "bolševikų viešpatavimo laikus", kuriuos iš dalies ir jam tekę pažinti. Anot jo, statybos batalionų kariai privalo atsiminti, kad tūkstančiai jų tautiečių buvo žiauriai nukankinti, dar daugiau jų ištremta ị Sibirą. Lietuvių tautos jau nebebūtų, jei krašte būtų pasilikę sovietai. Todèl neva negalima užmiršti "karžygiško vokiečių karių žygio", dẻl kurio Lietuva per kelias dienas išvaduota iš bolševizmo, negalima "stovèti nuošaliai" ir pasyviai "laukti pergalès". E. Justas maždaug taip nusakè statybos batalionų karių veiklos tikslus ir prasmę rytuose: "kovojančiam frontui" duoti daugiau naujų jègų, prisidèti prie jo stiprinimo, pergalès priartinimo, "lietuvių tautos vardu" atsidèkoti "išlaisvintojams" už "išvadavimą", siekti gero savo tautai, savo tėvų žemei, visai Europai ${ }^{110}$.

\footnotetext{
${ }^{107}$ Lietuviu enciklopedija, t. 28, p. 468.

${ }^{108}$ Borevičiaus J., Bitaičio A., Calkos A. 1944 m. parodymai. LVOA, f. 1, ap. 1, b. 99, 1. 23-24, 59, 86; Čekanavičiaus F. 1951. 07. 26 parodymai. Ten pat, f. 3377, ap. 55, b. 99, 1. 59.

${ }^{109}$ Gulmanas V. Rytuose vèl suplevèsavo nauja lietuviška trispalvè. Ateitis. 1943, birželio 3, Nr. 127 , p. 4.

${ }^{110}$ Sudarytas ketvirtasis lietuvių statybos batalionas. Ateitis. 1943 , birželio 9, Nr. 132, p. 1.
} 
Statybų batalionų išlydètuvès savo dirbtiniu iškilmingumu ir paradiškumu, dekoratyviu tautiškumu labai skyrèsi nuo palydų i Rytus daugelio lietuvių savisaugos batalionų, kurie išvykdavo vykdyti, atrodytų, daug svarbesnių Vokietijos reicho karo mašinai uždavinių, bet kurių išvykimas buvo slepiamas nuo visuomenès. Pavyzdžiui, $1941 \mathrm{~m}$. pabaigoje taip atsitiko 5-ajam savisaugos batalionui, išrikiuotam išlydètuvėms "vienos Šančiu senos kareivinès užkampyje tarp sugriautų namų"111.

Pabrežtinas dèmesys lietuvių statybos batalionams, be abejo, buvo okupantų anksčiau minètos propagandinès agitacinès akcijos, siekiant mobilizuoti lietuvių tautą į kovą prieš bolševizmą, mėginant sušvelninti didelès politinès nesėkmès formuojant SS legioną Lietuvoje ịspūdị, dalis. Vokiečiu okupacinio režimo atstovų kalbose ir oficialiojoje spaudoje atsispindẻjo po Vokietijos karinių nesėkmių karo frontuose pakitusios nuostatos ir požiūriai ị karinị bendradarbiavimą su lietuviais (ir kitomis okupuotomis Rytų Europos tautomis): buvo pabrezžama, kad statybos batalionai veiks vermachto sudetyje ir "globoje", artimai bendradarbiaudami su "vokiečių kariais" (o ne SS kariuomene ir policija). Šalia kartojamų senų nuvalkiotų štampų apie "išvadavimą" ir "kerštą bolševikams", atsirado naujos sąvokos, ivvardijančios "lietuvius karius", jų "garbingas pareigas", "artimą" bendradarbiavimą su vokiečių kariais. Taigi oficialioje propagandoje nuo lietuviu savanorių, stovinčiu "petys ị petị" su vokiečiu policija, pereita ị karinio bendradarbiavimo su vermachtu deklaravimą. Antai 5-ojo statybos bataliono suformavimas ir išsiuntimas ị pafrontę "Karyje" buvo vadinamas "kariuomenès aktu"112. Viso to nebuvo 1941-1942 m. formuojant lietuvių savisaugos batalionus, kai šie iš esmès kariniai daliniai buvo atiduoti vokiečių policijos žinion, politiniais sumetimais ịvairiais būdais maskuotos jų sąsajos su Lietuvos kariuomene.

Beje, su paskutiniuoju išsiųstu iš Panevėžio 5-uoju statybos batalionu atsisveikinta gana kukliai: jo kariai atsisveikinimo ceremonijai išrikiuoti "už Panevėžio miesto, laukuose"113. Lietuviams toliau boikotuojant paskelbtas mobilizacijas, Lietuvoje padidèjo ịtampa, $1943 \mathrm{~m}$. vasarą visoje Lietuvoje prasidẻjo žmonių gaudynès. Rugpjūčio pradžioje žmonès gaudyti ir Panevėžyje: rugpjūčio 2 d. - Panevéžio turguje, kitą dieną miesto kino teatruose suimta apie 30 žmonių. Taigi neliko pagrindo net ir dirbtiniam iškilmingumui ir paradiškumui.

${ }^{111}$ Lietuvos archyvai. Vilnius, 1998, kn. 11, p. 65.

112 Išsiruošè ị žygi penktasis lietuvių statybos dalinys: Kariuomenès aktas Panevėžyje. Karys. 1943, rugp. 7, Nr. 32, p. 2.

113 Ten pat.

276 


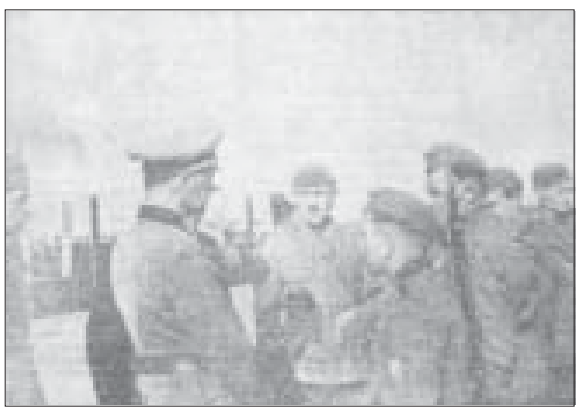

Ateitis, 19430501

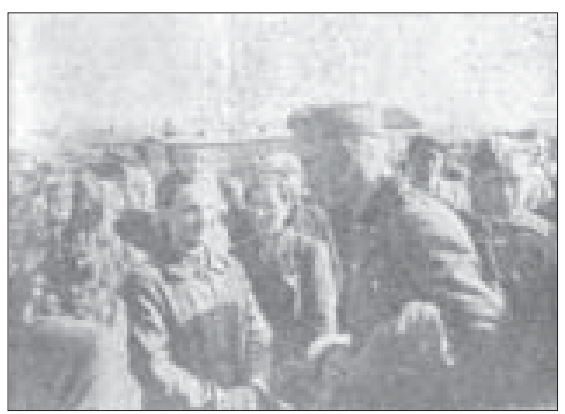

Panevėžio apygardos balsas,1943 0522

Viršuje: 2-ojo statybos bataliono išlydètuvès Panevėžyje 194305 05. Lietuvos karo komendanto E. Justo atstovas ir bataliono vadas plk. ltn. Vl. Strimas-Strimavičius kalbasi su kariais; bataliono kariai atsisveikina su giminemis ir artimaisiais. Apačioje: bataliono kariai žygiuoja miesto gatvemis

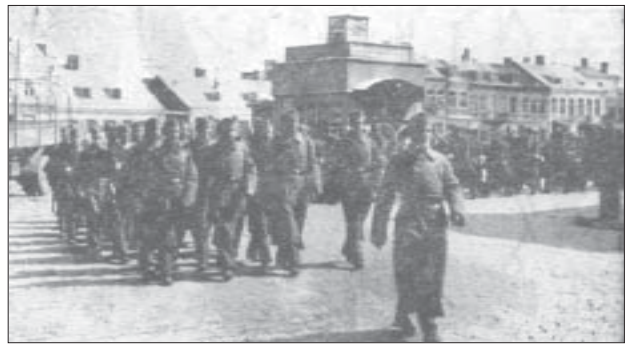

Savaite, 1943, Nr. 20, p. 309

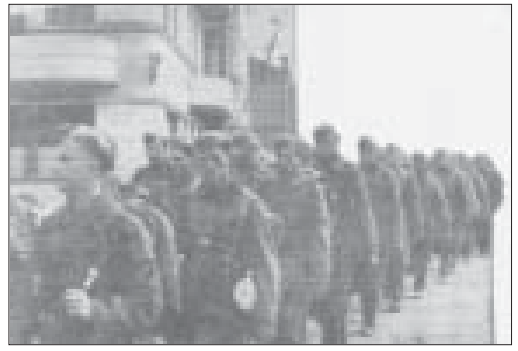

Savaite, 1943, Nr. 20, p. 309

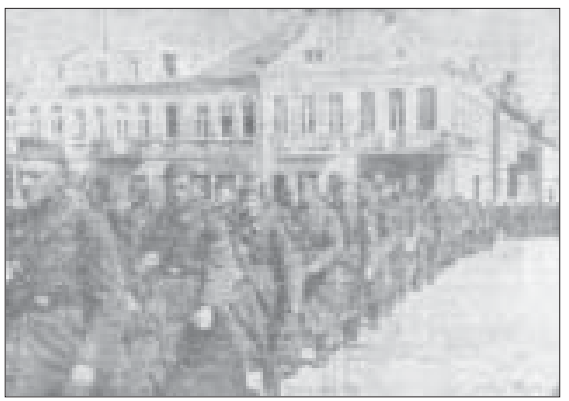

Ateitis, 19430517

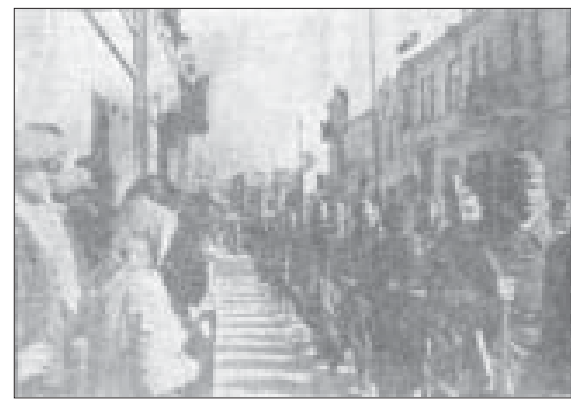

Panevežio apygardos balsas, 19430522 


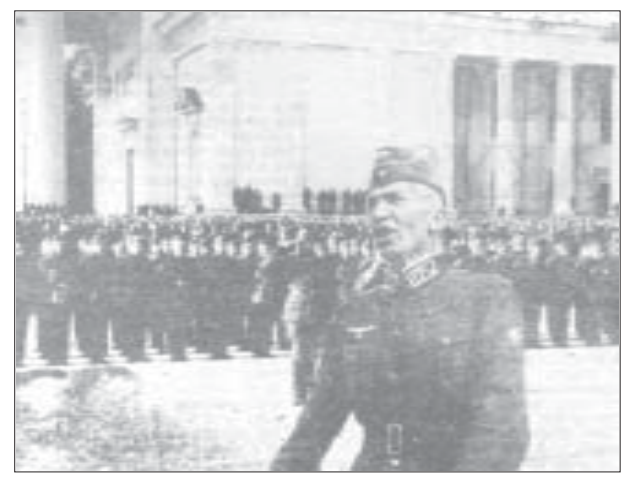

3-iojo statybos bataliono iškilmingos išlydètuvès Vilniuje, 19430602.

Kairèje - bataliono kariai išrikiuoti Katedros aikšteje, priekyje bataliono vadas mjr. S. Narušis; Apačioje - nuotraukų montažas "Ateityje" - iškilmių vaizdai (1943 06 07):

Centre - bataliono vadas mjr. $\mathrm{S}$. Narušis; su išrikiuotais kariais atsisveikina vermachto atstovas plk. Zehnpfenigas;

Savaite, 1943, Nr. 23, p.357
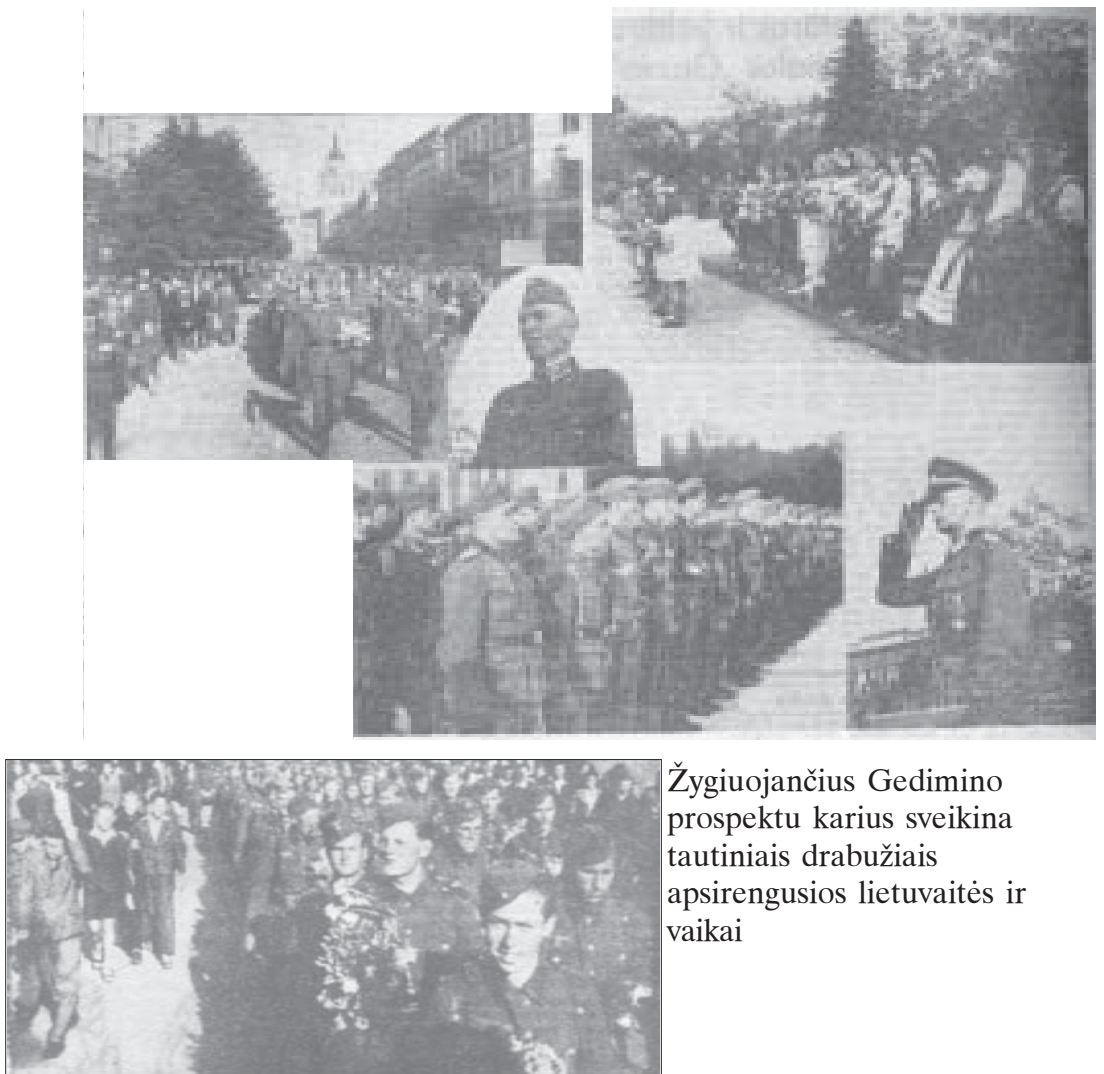

Žygiuojančius Gedimino prospektu karius sveikina tautiniais drabužiais apsirengusios lietuvaitès ir vaikai

Savaite, 1943, Nr. 23, p.357 


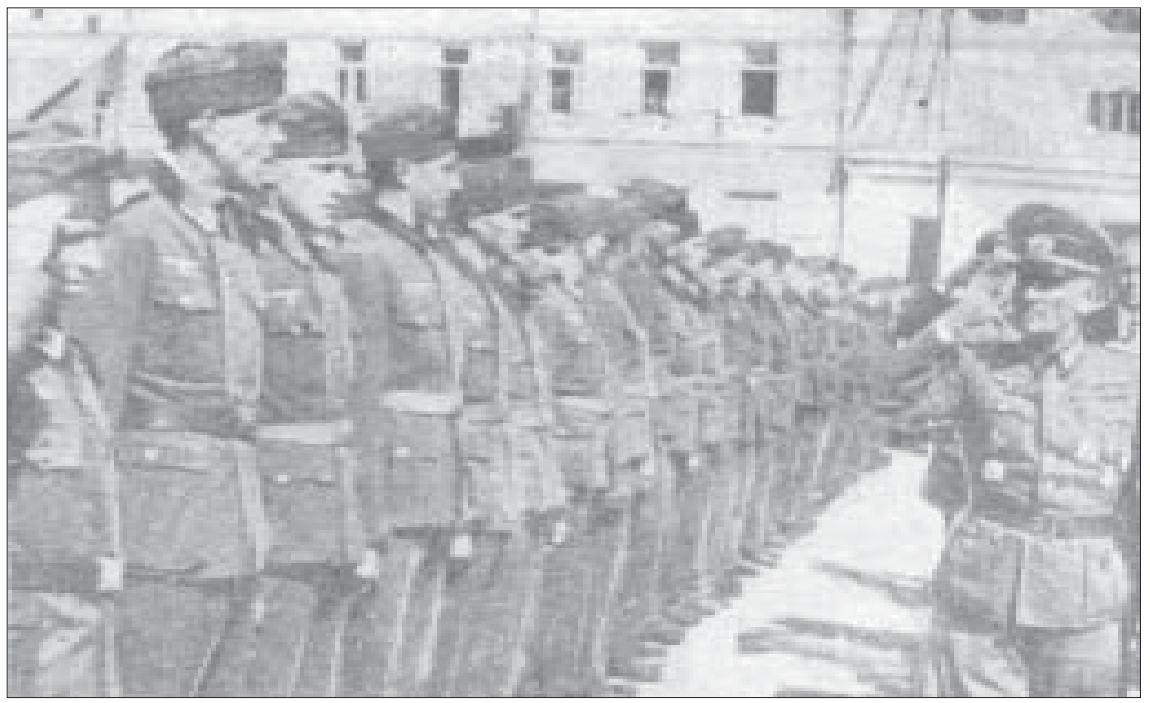

Savaite, 1943, Nr. 24, p.378

4-ojo statybos bataliono išlydėtuvès Panevėžyje, 19430608.

Su bataliono kariais ir jo vadu mjr. J. Černiumi atsisveikina E. Justas

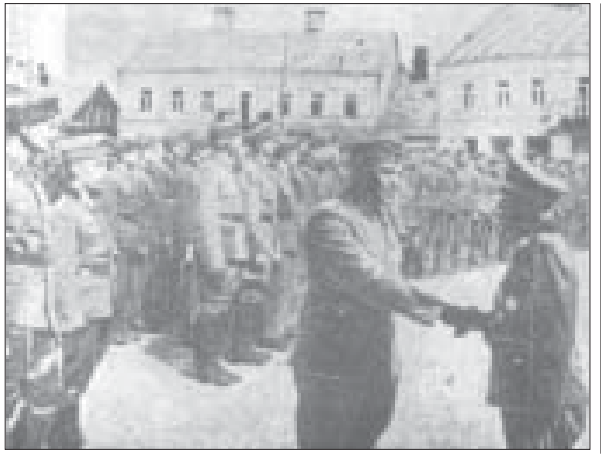

Savaite, 1943, Nr. 24, p.378

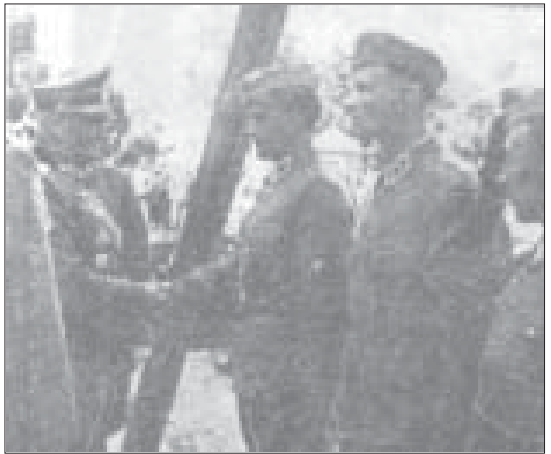

Savaite, 1943, Nr. 24, p.378 
Kokių būta panašumų ir skirtumų, formalių ir esminių, tarp lietuviu statybos ir savisaugos batalionų? 1943 m. pavasarị sužlugdžius SS lietuvių legiono steigimą, Lietuvai nebuvo lemta turèti SS kariuomenès dalinių, kurie būtų tapę frontinėmis karinėmis formuotemis. Lietuvių savisaugos batalionai, juo labiau statybos daliniai tokios formuotés nebuvo: savisaugos batalionai buvo pavaldūs SS ir policijai, statybos batalionai - vermachto vadovybei. Skirtingą pavaldumą galima laikyti formaliu dalyku, tačiau jis iš dalies lèmẻ ir skirtingą veiklos pobūdị: savisaugos batalionai iš pradžių saugojo geležinkelius, ivvairius kitus karinius ir ūkinius objektus ir pan., vèliau jų funkcijos plètėsi, jie naudoti kaip koviniai policijos daliniai, dažniausiai kovai su partizanais ${ }^{14}$, kai kurie batalionai atiduoti vermachtui dalyvavo kautynèse fronte. Tuo tarpu statybos batalionai buvo tik "vermachto talkininkai", jie niekada rimtai neruošti kovai fronte ir prieš partizanus (apskritai pionieriu daliniai tiesiogiai į kautynes nebuvo skiriami). Statybos batalionų kariai savisaugos batalionų karių atžvilgiu kartais vadinti "pagalbiniais savanoriais", apie kurių panaudojimą fronte "nė negalvojama", kartu neneigiant, kad ir tokiai tarnybai reikia gero, kruopštaus karinio parengimo ${ }^{115}$, jų veikla pafrontëje lyginta su vadinamujų "karo transportininkų" darbu.

Anot vieno rezistencijos šaltinio, statybos bataliono "jaunieji vyrai" dažnai nemokejo elgtis su šautuvu, užbyrèjusị žemėmis jo užraktą daužydavo ị žemę ir sugadindavo patị ginklą ${ }^{116}$. To nebuvo galima pasakyti apie savisaugos batalionų karius: bent iš pradžių ị savisaugos batalionus nebuvo priimami vyrai, netarnavę kariuomeneje, jų kariai išeidavo daug ilgesnį karinị parengimą. Galima tvirtinti, jog tarnyba savisaugos ir statybos batalionuose buvo skirtingų rūšiu karo tarnyba. Tiesa, $1944 \mathrm{~m}$. karo veiksmams okupuotose teritorijose einant ị pabaigą, abiejų rūšiu batalionų veiklos pobūdis supanašèjo: kai kurie demoralizuoti, kovose su partizanais ir puolančiais Raudonosios armijos daliniais nukentèję savisaugos batalionai dirbo kaip ir statybos batalionai: 1944 m. vasarą Kauno apylinkėse 2-ojo savisaugos bataliono padaliniai statė gynybinius ittvirtinimus vokiečiu armijai, 5-asis savisaugos batalionas Kurše saugodamas Baltijos pakrantę taip pat ruoše blindažus, kase apkasus ir kt. ${ }^{117}$ Yra tvirti-

\footnotetext{
${ }^{114}$ E. Justo parodymai, 1946 m. Laisvès kovu archyvas, t. 9, p. 136.

115 Pas mūsų lietuvių statybos batalionus. N. Biržų žinios. 1943, liepos 10, Nr. 27, p. 4.

${ }^{116}$ LVOA. Dokumentų rinkinys Nr. 167, p. 11.

117 Jackūno J. 1952. 03. 20 parodymai. Ten pat, f. 3377, ap. 55, b. 53, 1. 305; Vainausko-

Vainiaus J. 1950. 07. 01 parodymai. Ten pat, 1. 163.
} 
nimų, jog statybos batalionu tapo ir 13-asis lietuvių savisaugos batalionas $^{118}$. Ir atvirkščiai - statybos batalionams savo dislokacijos vietose teko vis dažniau susikauti su sovietiniais partizanais.

İvairių šaltinių duomenys apie atskirų statybos batalionų veiklą vokiečių Šiaurès fronto užnugaryje dirbant karinès reikšmès darbus, kovojant su partizanais, labai neišsamūs, fragmentiški, oficialioje spaudoje, saugant karinę paslaptį, jų numeriai nebuvo nurodomi, visų statybos batalionų veiklos pobūdis buvo nurodomas daugmaž vienodas. Vis dèlto apie statybos batalionus, jų dislokacijos vietas, veiklos ypatumus galima pateikti ir konkrečių duomenų.

1-asis statybos batalionas buvo suformuotas $1943 \mathrm{~m}$. balandžio mènesị Kaune, Panemuneje, iš Kauno ir Kauno apygardos gyventojų. Jo sudėtyje, matyt, buvo ir vokiečių padalinių. Dislokuotas batalionas Lugos apylinkèse netoli Tolmačiovo Maloje Zamošje, Bolšoje Zamošje ir kituose kaimuose (geležinkelio Pskovas-Leningradas dešinèje pusèje). Čia bataliono kariai kirto mišką ir rąstais grinde kelią, iš viso jo nutiesè apie $10 \mathrm{~km}$. Rąstais grịsti keliai (vok. - knüppelweg) tiesti ir per smėlynus, kuriuos sunkiai įveikdavo karinè technika. Medžiai tokiems keliams buvo kertami čia pat, miške, pjaustomi ir guldomi smėlyje vienas prie kito, ju galai surišami vielomis ${ }^{119}$. Atskiras bataliono padalinys dirbo prie geležinkelio tiesimo darbų $^{120} .1943 \mathrm{~m}$. rugsėjo mėnesį iš Lugos apylinkių batalionas perkeltas ị Pskovo apylinkes (ịkurdintas Koniečik, Židilov Bor, Kliuji ir kt. kaimuose), kur statẻ priešakinès gynybos liniją vokiečių armijai: kasẻ prieštankinius griovius, apkasus, montavo gelžbetoninius įtvirtinimus. 1944 m. pradžioje panašaus pobūdžio darbams batalionas perkeltas i Baltarusiją - Polocko, vèliau Breslavlio (Breslaujos) apylinkes. Čia batalionas išformuotas, jo kariai paskirti ị vokiečių armijos 793-iaji pionierių batalioną ir jo sudètyje traukèsi per Latviją, atsidūrè Kuršo "katile", su apsupta vokiečių Kuršo grupuote 1945 m. pavasari pateko Raudonajai armijai i nelaisvę ${ }^{121}$.

2-asis statybos batalionas suformuotas $1943 \mathrm{~m}$. balandžio mėnesi Pa-

118 Knezys St. Kauno karo komendantūros Tautinio darbo batalionas $1941 \mathrm{~m}$. Genocidas ir rezistencija, 2000, Nr. 1(7) p.143; Stankeras J., min. veik., p. 191.

${ }^{119}$ Nagys Pr., min. veik., p. 65.

${ }^{120}$ Augustinavičius P. Lietuvių stat/ybos/ bataliono darbai Rytuose. Karys. 1943, rugsèjo 18, Nr. 38 , p. 12.

${ }^{121}$ Buvusių 1-ojo statybos bataliono karių: Čekanausko F. 1951. 07. 24, 26 parodymai. LVOA, f. 3377, ap. 55, b. 59, 1. 97-100; Noviko Vl. 1951. 07. 24 parodymai. Ten pat, 1. 101-102; Vilkaičio K. 1951. 08. 02 parodymai. Ten pat, 1. 103; Milerio St. 1951. 08. 06 parodymai. Ten pat, 1. 105; 5-ojo bataliono ltn. Borevičiaus 1944 m. parodymai. Ten pat, f. 1, ap. 1, b. 99, 1. 23-24. 
nevėžyje. Išsiunčiant ši batalioną i rytus, "Karyje” rašyta, jog, "neskaitant Kauno, pirmą kartą buvo sudarytas grynai lietuviškas statybos batalionas, visi jo kariai kilę iš Panevéžio ir jo apylinkių"122. Batalionui vadovavo plk. ltn. Vl. Strimas-Strimavičius (1939 m. - Lietuvos kariuomenès 9-ojo pėstininku pulko 3-iojo bataliono vadas) ${ }^{123}$. Tolmačiovo apylinkèse batalionas ịkurdintas kaireje geležinkelio Pskovas-Leningradas pusėje, vasarnamiuose prie Lugos upès, ir dirbo tuos pačius darbus kaip ir 1-asis batalionas.

Bataliono vyrai, turejję prisidėti prie "didžio darbo - Europos apsaugojimo ir bolševizmo sunaikinimo", iš pat pradžių nepasižymėjo drausme ir susitelkimu, o formavimo metu iškrètè nemažai chuliganiškų išdaigų, pradejjo konfliktus su Panevėžio gyventojais ir policija. Tai tęsèsi ir nuvykus ị pafrontę. J. Borevičiaus tvirtinimu, batalione ịvykęs "maištas", po kurio suimta bataliono karių, pakeisti vadai, keliolika kareivių sušaudyta už dezertyravimą ${ }^{124}$. Šiuos faktus savo atsiminimuose patvirtina ir Pr. Nagys: "gerai išgėrę" bataliono karininkai sukẻlẻ susišaudymą tarp dviejų kuopų. Vokiečiai pamanè, kad užpuolè partizanai, todėl gerai apsiginklavę kulkosvaidžiais èjo "ginti” lietuvių. Bataliono ir kuopos vadai buvo areštuoti, vieną kuopą nuginklavo, ginklus galëjo turéti tik einantys į sargybą, kuopos vadu paskirtas vokietis viršila ${ }^{125}$. Bataliono vadu paskirtas kpt. A. Milaševičius (buvęs Lietuvos kariuomenès 2-ojo kavalerijos pulko karininkas), vokiečių pakeltas ị majorus. Pasak Pr. Nagio, pafrontejje jis mégo jodinèti ant arklio, nelauktai atsirasti "visur, kur tik buvo kareivių", vilkėjo lietuvišką uniformą ir buvo daug šaunesnis už vokiečių karininkus. Tuo lietuviai kariai labai didžiavosi ${ }^{126}$ (antra vertus, dèl reiklumo ir uolumo kareivių nemėgtas). Matyt, mjr. A. Milaševičiaus pastangomis batalione buvo ịvesta tvarka. $1944 \mathrm{~m}$. pradžioje plk. A. Birontas kaip Lietuvos Tarybos (išrinktos 1943 m. balandžio 5 d. visos Lietuvos konferencijoje ir veikusios kaip "patariamasis" organas prie pirmojo generalinio tarejjo P. Kubiliūno) narys aplankẻ visus lietuvių statybos batalionus. Jis išskyre 2-ajį statybos batalioną, kuris padaręs tikrai "gerą ìspūdị”. Visi vyrai atrodè sveiki, užsigrūdinę, turèjo geras gyvenimo ir darbo sąlygas, tačiau batalione pasigedo lietuvių gydytojų ir kapelionų ${ }^{127}$.

\footnotetext{
${ }^{122}$ Panevėžyje sudarytas lietuvių statybos batalionas. Karys. 1943, gegužès 22, Nr. 21, p. 1.

${ }^{123}$ Karininku metraštis. 1939 m. Kaunas, 1939, p. 34.

${ }^{124}$ Borevičiaus J. parodymai, 1944 m. LVOA, f. 1, ap. 1, b. 99, 1. 24

${ }^{125}$ Nagys Pr., min. veik., p. 64.

126 Ten pat, p. 64, 68.

${ }^{127}$ Plk. Birontas aplankė lietuvių statybos batalionus. Ateitis. 1944, vasario 7, Nr. 31, p. 2.
} 


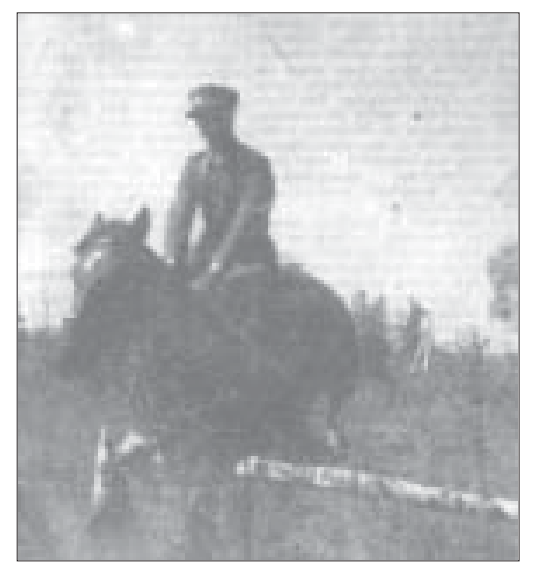

Savitarpinès pagalbos žinios, 19431018

2-ojo statybos bataliono vadas

kpt. A. Milaševičius raitas tikrina sargybas
1943 m. rugsejjo mėnesị batalionas perkeltas į Pskovo apylinkes, čia statė bunkerius, ruošė lizdus patrankoms, kasė prieštankinius griovius, kirto mišką ${ }^{128}$. Pr. Nagio tvirtinimu, iš Pskovo apylinkiu $1944 \mathrm{~m}$. kovo $17 \mathrm{~d}$. batalionas išžygiavo ị Estiją, iš jos geležinkeliu atvyko ị Lietuvą. Sovietiniu partizanų Lietuvoje žvalgybos duomenimis, 2-asis ir 4-asis statybos batalionai jau kovo $4 \mathrm{~d}$. atvyko ị Zarasu aps. Abu batalionai apsistojo Salake, Lupenkos, Rusteikių, Gumbiškių, Grybiškių ir kt. kaimuose ${ }^{129}$. Sovietiniu partizanu šaltiniuose tvirtinama, jog kareiviai keitė ginklus ị samanę, masiškai dezertyravo. Per vieną naktį iš Rusteikių kaime apsistojusių 130 karių teliko 40 (kaip matyti iš kitu šaltinių, kariams buvo duodamos trumpalaikès atostogos) ${ }^{130}$. Vokiečiai sutikusius išvykti ị frontą karius išvežè, kitus nuginklavo ir vare ị darbus kaip belaisvius. Lietuviai kariai kartu su vietos gyventojais Zarasų aps. kirto mišką, tarp Turmanto, Smalvų ir kitų ežerų kasė apkasus, iš rąstų dare bunkerius (šie bunkeriai buvo Daugpilio gynybinio rajono įtvirtinimų tęsinys). 1944 $\mathrm{m}$. balandžio mėnesị šie darbai nutraukti, dalis karių išvežti Daugpilio kryptimi.

3-iasis statybos batalionas Vilniuje formuotas iš Vilniaus apygardos gyventojų. Apie bataliono formavimą jo vadas mjr. S. Narušis (1939 m. tarnavo Lietuvos kariuomenès štabe, spaudos ir švietimo skyriuje) 1943 m. balandžio 15 d. Vilniaus Filharmonijos didžiojoje salëje padarè pranešimą miesto visuomenei. I batalioną karininkai, veterinarijos ir sanitarijos gydytojai registruoti Vilniuje, Kosčiuškos g. 5/7-3. Užsiregistravusieji turèjo rinktis Artilerijos kareivinėse Šnipiškèse. Tuo metu batalionui trūko kuopų vadų, jaunesniụjų karininkų, puskarininkių, kareivių,

\footnotetext{
${ }^{128}$ Nagys Pr., min. veik., p. 69.

${ }^{129}$ Ten pat, p. 76; Šumausko M. 1944. 05. 21 radiograma A. Sniečkui. LVOA, f. 1, ap. 1, b. 412,

1. 251; LPJŠ 1944. 05. 25 Žvalgybos duomenų santrauka Nr. 10/28. Ten pat, b. 24, 1. 23.

${ }^{130}$ Griciaus Pr. 1948. 08. 20 parodymai. Ten pat, f. 3377, ap. 55, b. 47, 1. 189.
} 
įvairių specialistų. Batalionas galutinai turejjo būti sukomplektuotas Ukmergeje ${ }^{131}$, tačiau ar taip buvo iš tikrujjų, duomenų nèra.

1943 m. spalio mėnesị mjr. S. Narušis savo ir bataliono karių, "sunkiai dirbančiu Rytuose", vardu dėkojo bataliono rẻmejjams už atsiųstą radijo aparatą, kaip "brangią dovaną kariams, nuvargusiems nuo darbo, išsikankinusiems nakties metu nuo banditų partizanų siautimo" ${ }^{132}$. Šie bataliono vado žodžiai, paskelbti oficioze "Ateitis", rodo iš tiesų nelengvą 3-iojo statybos bataliono padètị rytuose. İdomi detalẻ užfiksuota sovietinio partizanų būrio "Bičiuliai" (vadas J. Vildžiūnas) 1944 m. dokumentuose: "fašistinè", matyt, pogrindiné, Lietuvos laisvės armija (LLA) (palaikiusi ryšius su sovietiniais partizanais - R. Z.) praneša, kad iš 3-iojo bataliono pabėgo 124 savanoriai ${ }^{133}$.

4-asis statybos batalionas suformuotas iš Panevéžio apygardos gyventojų, jam vadovavo mjr. Juozas Černius (buvęs Lietuvos kariuomenès 7-ojo péstininku pulko 1-ojo bataliono vadas). 1940-1941 m. jis buvo pasitraukęs ị Vokietiją ir ten gyveno, i̇ Lietuvą atvyko specialiai formuoti statybos bataliono, buvo vienas iš aktyvesnių ir uolesnių bataliono karininkų. 1944 m. pavasarị mjr. J. Černius spaudos atstovams pareiške, jog "sugrịžus ị tėvynę susidarąs įspūdis, jog visi tie sluoksniai, kurie iš tikrųjų turètų šaukti tautą į darbą, daugiau kalba negu veikia", surizgusios nuotaikos tévynejje karių atostogas padaro nemalonias, pasakojo apie jo vadovaujamo bataliono kautynes su bolševikais ${ }^{134} .1944 \mathrm{~m}$. kovo ménesị iš Pskovo apylinkių batalionas kartu su 2-uoju batalionu sugrąžintas ị Lietuvą (Zarasų aps.).

5-asis statybos batalionas iš Panevėžio ị vokiečiu Šiaurès fronto užnugarị išvyko vèliau negu kiti batalionai, išèjo trumpą 4 savaičių mokymą, jo karių dauguma buvo pirmąkart apvilkti karine uniforma ${ }^{135}$. Batalionas dislokuotas Tolmačiovo apylinkèse Boloto kaime. $1943 \mathrm{~m}$. rugsejjo mènesi buvo perkeltas ị Ostrovo apylinkes (30 km ị pietryčius nuo Ostrovo, Vyly, Babino, Batary kaimai). Batalionas priklausė 510-ajam vokiečiu

\footnotetext{
${ }^{131}$ Apie organizuojamus statybos batalionus. Karys. 1943, balandžio 24, Nr. 17, p. 8.

${ }^{132}$ Frontas ir tèvynè. Ateitis. 1943, spalio 12, Nr. 237, p. 1.

${ }^{133}$ LVOA, f. 59, ap. 1, b. 1, 1. 100.

${ }^{134}$ Lietuvių karių tvirtas pasiryžimas (Lietuvio majoro Černiaus pareiškimas spaudos atstovams). Ateitis. 1944, birželio 3, Nr. 128, p. 8.

${ }^{135}$ Išsiruošè į žygi penktasis lietuvių statybos batalionas. Karys. 1943, rugpjūčio 7, Nr. 32, p. 2. 284
} 
pionierių batalionui, statė ịtvirtinimų liniją prie Velikajos upès ${ }^{136}$. (Bataliono vadas - mjr. St. Nagrodskis 1919 m. vadovavo Žiežmarių komendantūrai, $1920 \mathrm{~m}$. pabaigoje - 2-ojo raitelių pulko kapitonas, ūkio vedèjas, vẻliau išèjo ị atsargą.) Batalionas nepasižymejjo drausme, jame, kaip ir 2ajame batalione, $1943 \mathrm{~m}$. rudeni kilo neramumų, kurių metu neapsieita be apsišaudymu $u^{137}$. Bataliono nuotaikas atspindi ir kai kuriu jo karių užmegzti ryšiai su sovietiniais partizanais, veikusiais kitoje Velikajos upés puséje: 1943 m. rudeni grupelè karių persikèlẻ per šią upę ir, vieno kaimo seniūno padedami, užmezgè ryšius su partizanais, vedẻ derybas dèl didelės bataliono karių grupés perejimo pas partizanus. Tam neprieštaravę ir kai kurie bataliono karininkai. Vienos kuopos vadas pasakęs: "žinokitès, pas vokiečius irgi nèra gyvenimo"138. Tačiau pas partizanus su ginklais perëjo tik 13os kariu grupè. Lietuviai kariai nesiryžę bėgti pas partizanus. İdomi detalè: lietuviai bijoję būti sušaudyti už tai, kad karo pradžioje bėganti iš Lietuvos Raudonoji armija buvo apšaudoma lietuvių sukilèlių. Sovietinių partizanų vadai įtikinėję, jog tai "neturi reikšmės”139.

Vienas iš bėgimo pas partizanus iniciatorių ir organizatorių buvo 5-ojo statybos bataliono būrio vadas leitenantas J. Borevičius, pats 1943 m. spalio ménesi peréjęs pas partizanus. Jis ši savo poelgi $1944 \mathrm{~m}$. parodymuose KGB aiškino noru išpirkti kaltę "tarybinei tėvynei" už padarytus nusikaltimus tarnaujant apsaugos bataliono Alytaus kuopos smogiamojo būrio vadu ${ }^{140}$. (J. Borevičius bene vienintelis lietuvių statybos ir savisaugos batalionų karininkas, savanoriškai perējęs pas sovietu partizanus; savisaugos batalionu karininkas ltn. Vl. Šlapelis partizanu tapo patekęs i nelaisvę Baltarusijoje). Informuotas apie statybos bataliono lietuvio karininko perejjimą pas Leningrado partizanus, LPJŠ viršininkas A. Sniečkus 1943 m. prašè Centrinio partizaninio judejjimo štabo

${ }^{136}$ Borevičiaus J. 1944 m. parodymai. LVOA, f. 1, ap. 1, b. 99, 1. 84; Ogintas A. Mano prisiminimai iš partizaninio gyvenimo, 1944 m. Ten pat, f. 3377, ap. 3377, b. 813, 1. 1-2; Centrinio partizaninio judejjimo štabo žvalgybos skyriaus viršininko S. Anisimovo 1943. 10. 30 pranešimas LPJŠ. Ten pat, f. 1, ap. 1, b. 18, 1. 192.

${ }^{137}$ Calkos A. parodymai 1944 m. Ten pat, f. 1, ap. 1, b. 99, 1. 89; Borevičiaus J. parodymai. Ten pat, 1. 84.

${ }^{138}$ Bitaičio A. parodymai 1944 m. Ten pat, f. 1, ap. 1, b. 99, 1. 59.

${ }^{139}$ Oginto A. 1944 m. parodymai. Ten pat, b. 100, 1. 3.

${ }^{140}$ Borevičiaus J. baudžiamoji byla LYA, b. 44908/3, p. 32. 
vadovybę pasiųsti ji per fronto liniją LPJŠ žinion, nes jis galëjo suteikti vertingų žinių apie padétị Lietuvoje, būti "efektyviau” negu Leningrado srities partizanų panaudotas propagandos tikslais ${ }^{141}$. Tačiau J. Borevičius ir kiti perbėgę pas partizanus lietuviai kariai atiduoti LPJŠ žinion tik 1944 m. gegužès ménesi, kai Leningrado sritis buvo išvaduota, joje veikę partizanų junginiai išformuoti.

Viliodami pas save statybos batalionų karius, sovietiniai partizanai demagogiškai žadejo leisti pasirinkti, kur partizanauti: Leningrado srityje arba Lietuvoje. Iš lietuvių karių sudarytas atskiras partizanų būrys, veikęs Leningrado 3-iojoje A. Germano brigadoje, jo vadu paskirtas J. Borevičius, lietuvių karių buvo ir kitose brigadose. 5-ojo statybos bataliono kariai, savo noru ar priverstinai (patekę į nelaisvę) tapę sovietiniais partizanais, dalyvavo Leningrado partizanų kovinėje veikloje, diversijų ir propagandos tikslais buvo siunčiami ir į Latviją. Partizanų gretose buvo ir žuvusių lietuvių karių (Žalneravičius, N. Gansinevičius). Tačiau ị Lietuvą "partizaninei kovai” jie nebuvo siunčiami. Neleidžiant lietuviams kariams sugrižti "partizanauti” ị Lietuvą, netesint kitų demagoginiais tikslais Leningrado partizanų duotų pažadų, nusivylę realia partizaninio ir sovietinio gyvenimo tikrove, kai kurie lietuviai kariai bande dezertyruoti ir iš partizanų būrių. Dezertyravę panevéžiečiai Bogužas ir Janulevičius buvo sugauti, sugaunami pasipriešino ir buvo sušaudyti. Už rodytą nepasitenkinimą ir "viešą" (antitarybinę? - R. Z.) kalbą buvo sušaudytas ir vienas pirmujuc perejusių pas partizanus karių - Bieliauskas. Tokio pat likimo vos išvenge ir pats J. Borevičius ${ }^{142}$.

Nera pagrindo tvirtinti, kad Leningrado partizanų būriuose buvo daug pabėgusių iš 5-ojo ir kitų statybos batalionų lietuvių karių. Dezertyravę kariai bėgo ne pas partizanus, o ị Lietuvą. J. Borevičiaus tvirtinimu, 1943 m. rudeni iš 5-ojo statybos bataliono 35 ginkluoti kariai pabėgo ị Latvijos pusęę43. Koks nelengvas, kartais nesėkmingas bėgusių i Lietuvą lietuvių karių kelias, matyti iš A. Calkos parodymų. Pabėgęs kartu su kitu 5-ojo bataliono kariu Ostrovo apylinkėse, atejo ị Latviją, traukiniu pasieke Rygą, čia susitiko su dar vienu lietuviu, dezertyravusiu iš 2-ojo sta-

${ }^{141}$ LPJŠ viršininko A. Sniečkaus 1943 m. raštas CPJŠ viršininko pavaduotojui Belčenkai. LVOA, f. 1,ap. 1, b. 22, 1. 132.

${ }^{142}$ Borevičiaus J. parodymai 1944 m. Ten pat, f. 1, ap. 1, b. 99, 1. 84-85; Ogintas A. Mano prisiminimai... Ten pat, f. 3377 , ap. 3377 , b. $813,1.2$.

${ }^{143}$ Ten pat, f. 1 , ap. 1 , b. $99,1.21,84-85$.

286 
tybos bataliono. Bègliams Lietuvos pasiekti nepavyko: jie Bauskès apylinkèse prie pat Lietuvos sienos latvių aiszargų buvo sulaikyti, sumušti, nes palaikyti sovietiniais desantininkais, atiduoti vokiečiu žandarmerijai, 2 ménesius išlaikyti kalëjime Rygoje ir pasiųsti atgal ị savo dalinius. 5-asis statybos batalionas jau buvo išformuotas, todèl siųstieji pateko ị vokiečiu dalinį, iš kurio pabègo pas sovietų partizanus ${ }^{144}$.

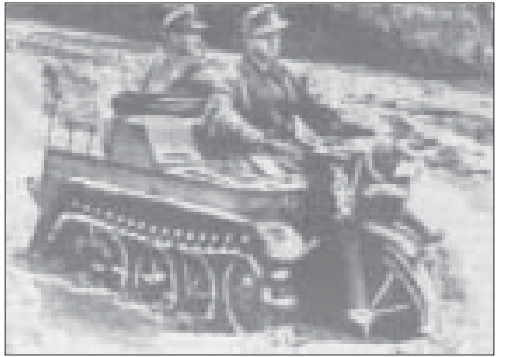

Savaite, 1943, Nr. 7, p. 99

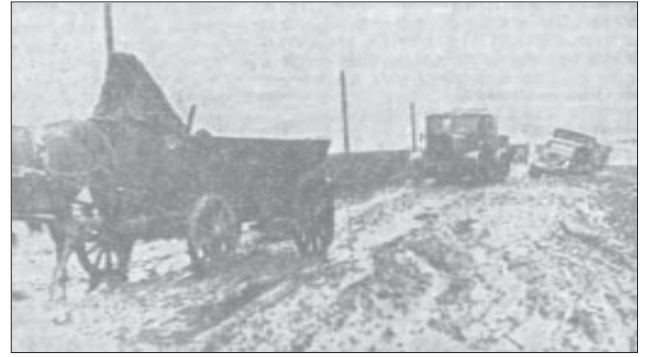

Karys, 19430410

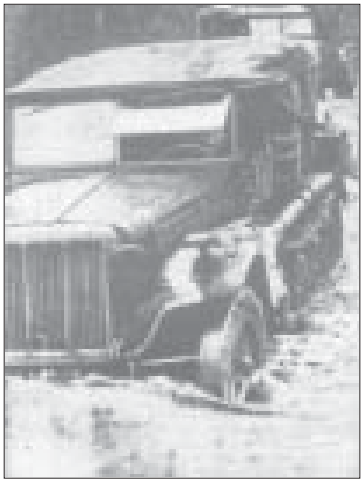

Savaite, 1943, Nr. 7, p. 99

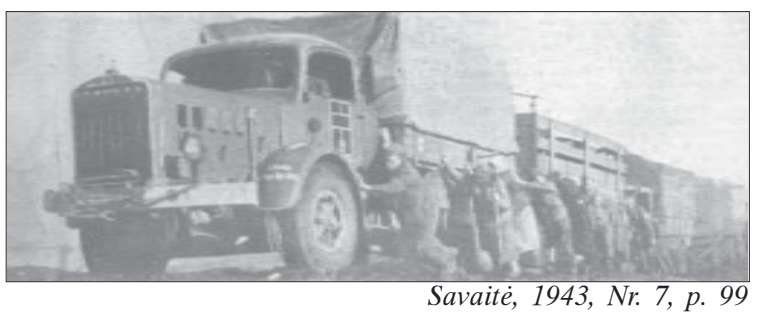

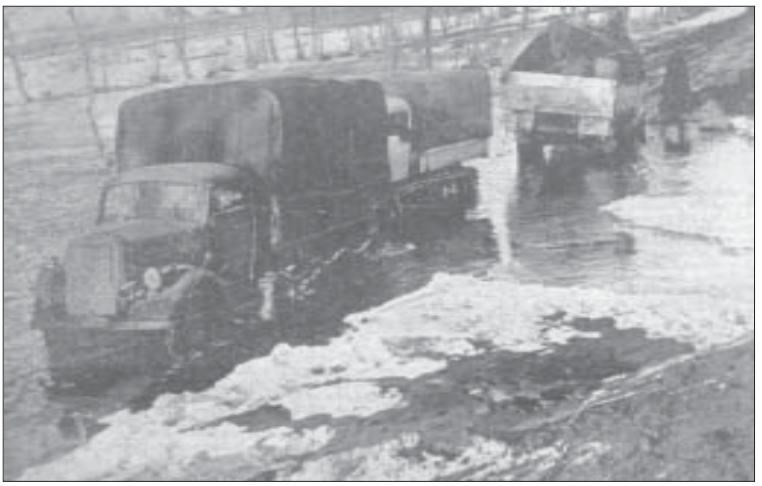

Savaite, 1943, Nr. 17, p. 259

Sunkiai ịveikiami vokiečiu technikai frontiniai keliai Rusijoje. Tiekimo transportui ì pagalbą ateidavo ịvairių tipu vikšriniai vilkikai, taip pat ir prie kelių taisymo darbų suvarytos rusés moterys.

${ }^{144}$ Calkos A. parodymai 1944 m. Ten pat, 1. 87-88. 


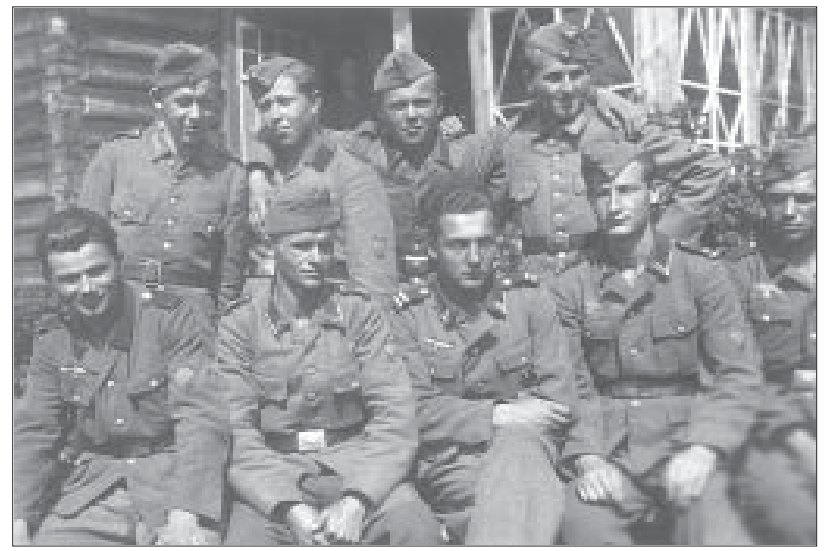

1-ojo statybos bataliono karių grupé (S. Natkevičiaus asmeninis archyvas)
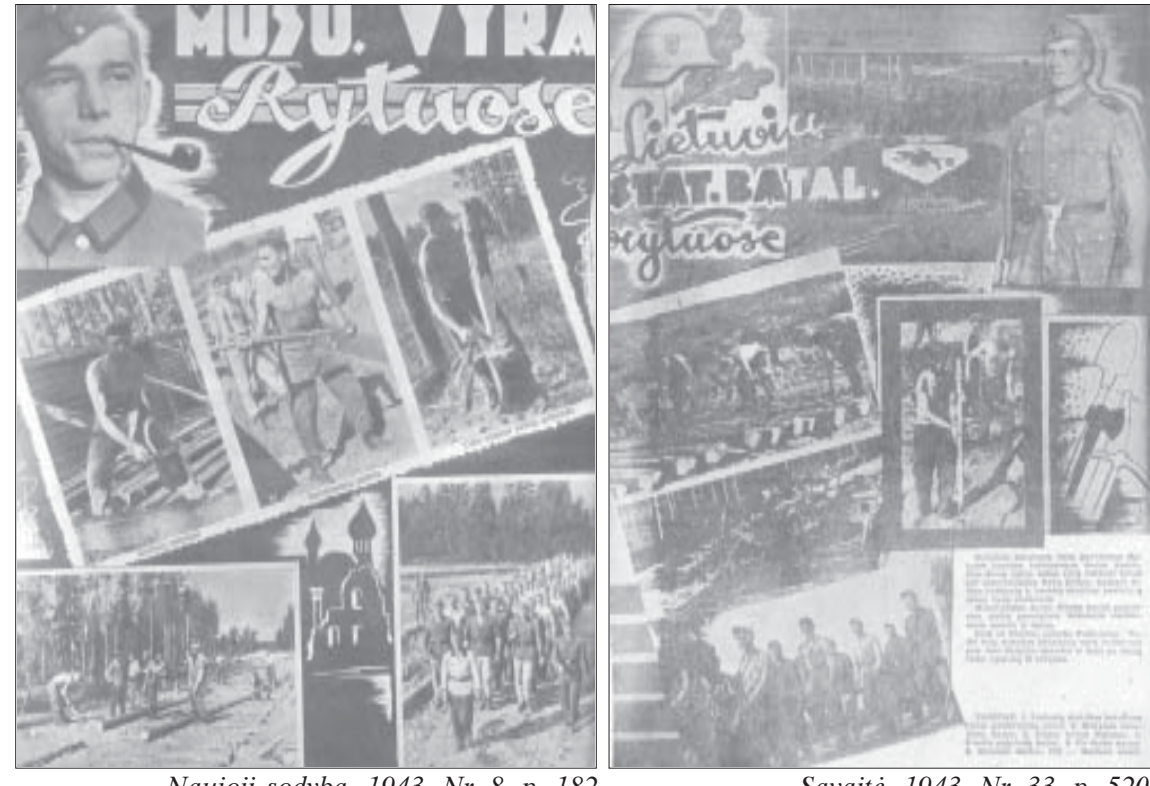

Naujoji sodyba, 1943, Nr. 8, p. 182

Savaite, 1943, Nr. 33, p. 520

Nuotraukų ir piešinių montažai apie statybos batalionų veiklą rytuose Lietuvoje leistuose žurnaluose.

Viršuje - statybos batalionas dirba prie keliu tiesimo darbų. Dešinejje atkreiptinas dẻmesys ị dailininko nupieštus batalionų karių darbo įrankius. Jie, o ne ginklai buvo pagrindiniai lietuvių statybos batalionų veiklos rytuose simboliai. 


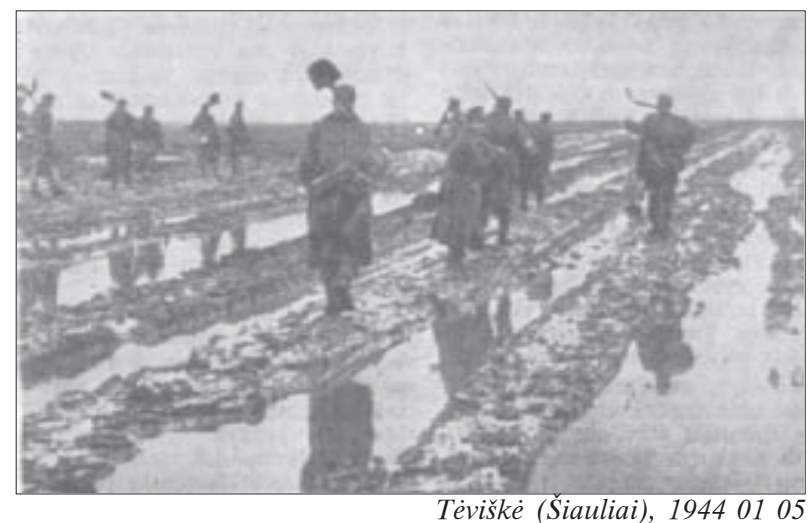

Lietuvių statybos batalionu kariai ir vokiečiu pionieriai tiesia ir taiso kelius

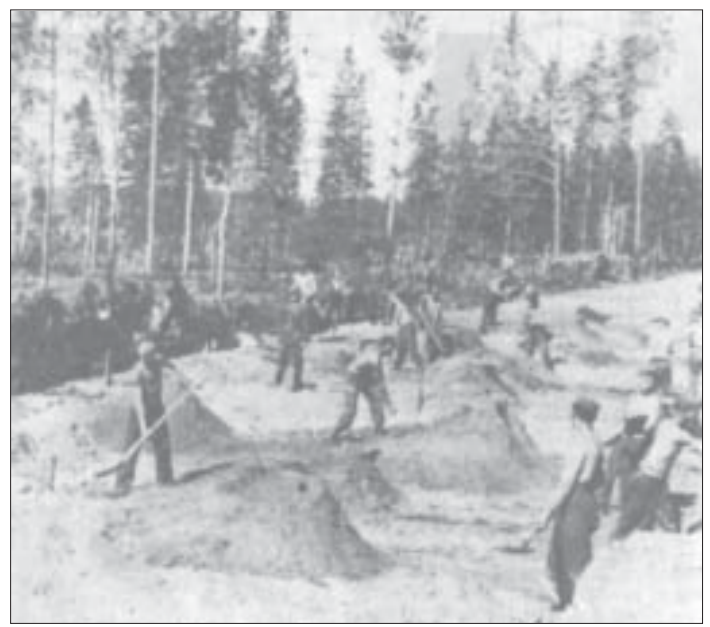

Karys, 19431002

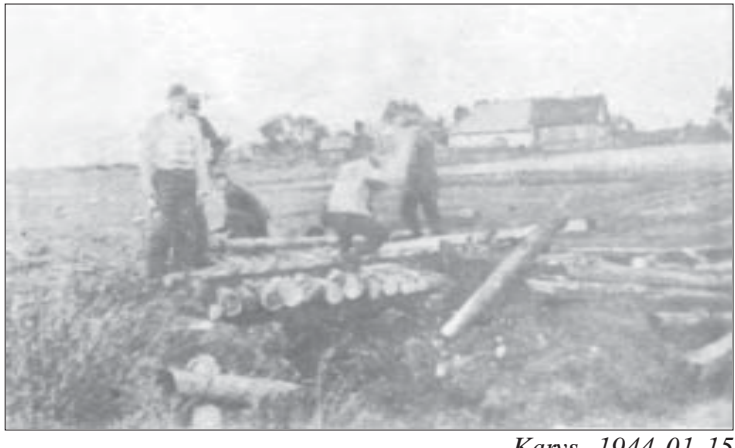

Karys, 19440115 


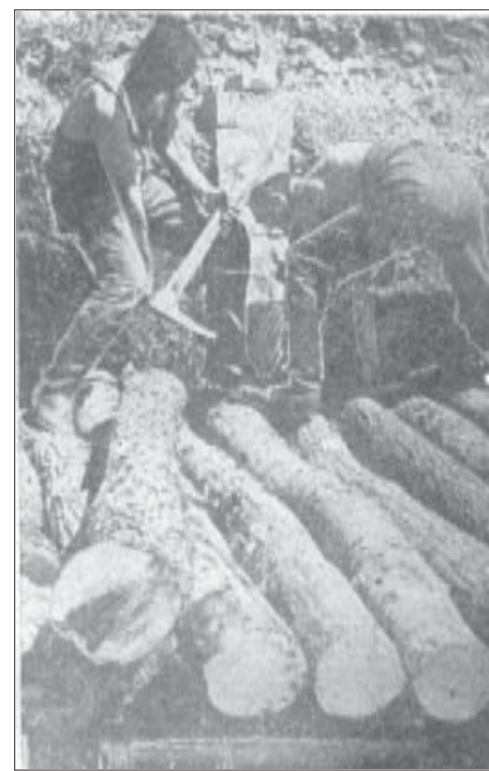

Savaite, 1943, Nr. 37, p. 576

Bunkerių ir kitų gynybinių itvirtinimų statyba rytuose. Svarbiausia statybinė medžiaga buvo medžių rąstai
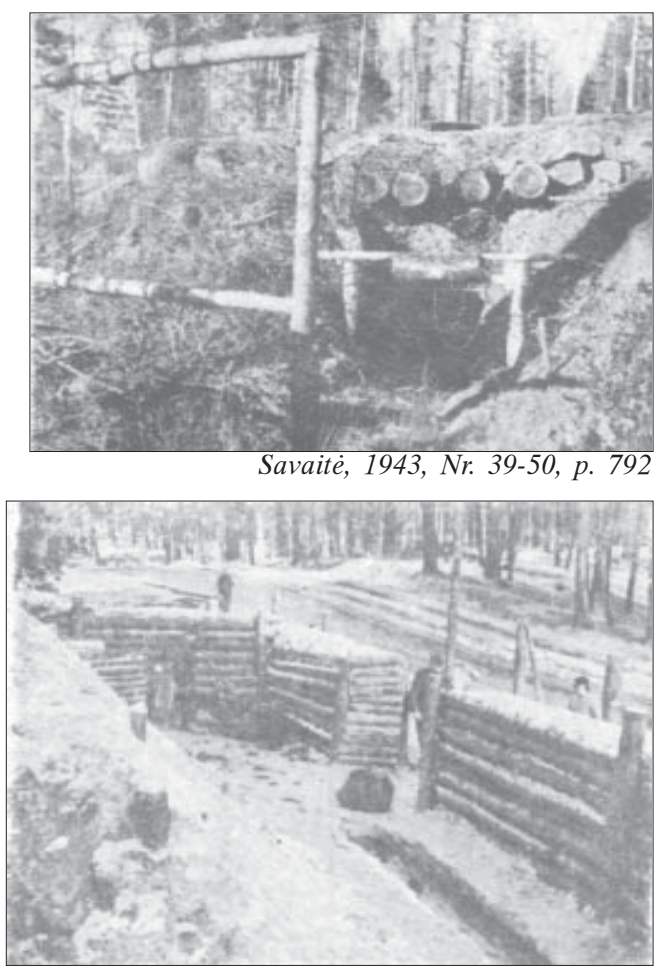

Karys, 19440226

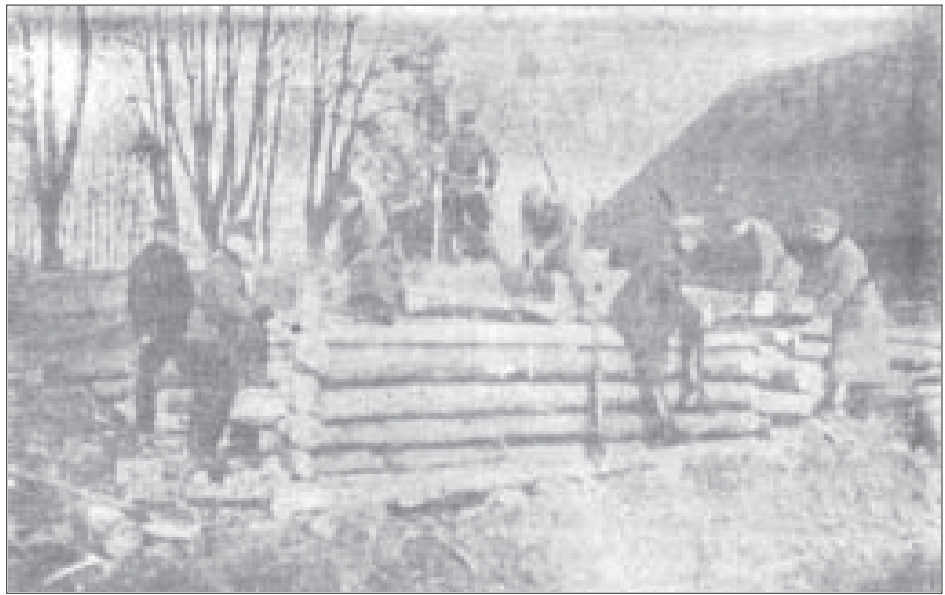

Karys, 19440115 


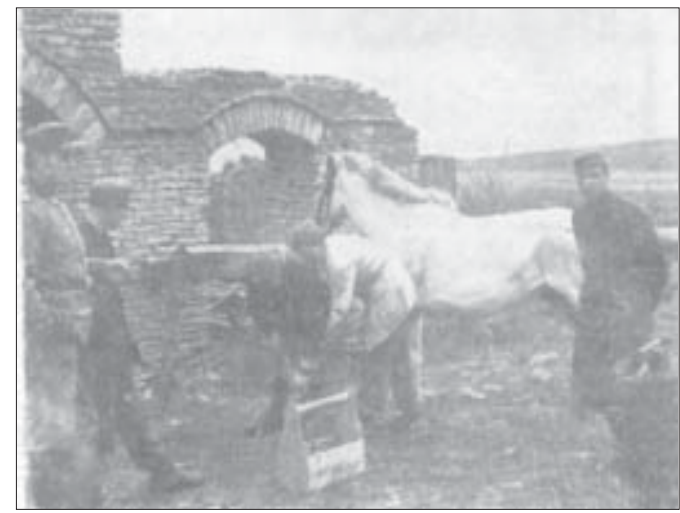

Karys, 19431223

Statybos batalione kaustomi arkliai

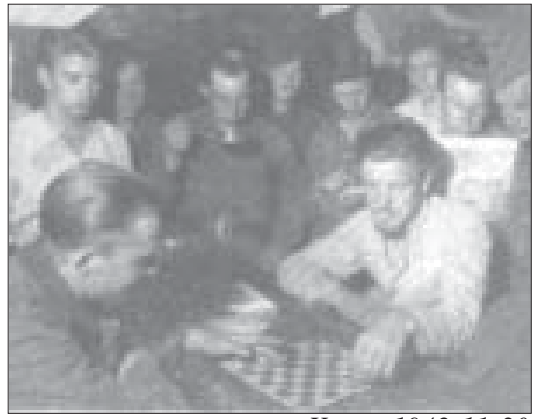

Karys, 19431120

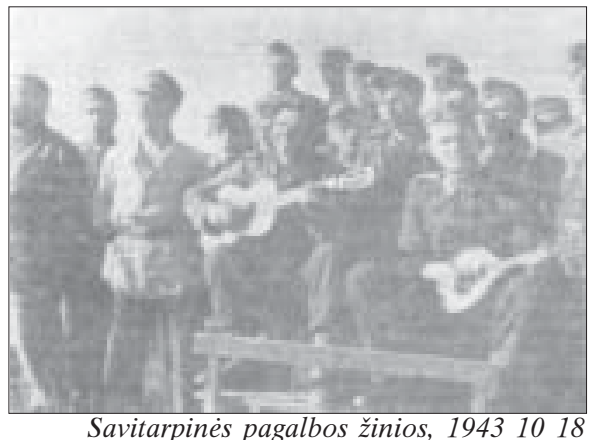

Savitarpinès pagalbos žinios, 19431018

Statybos batalionuc kariai poilsio metu

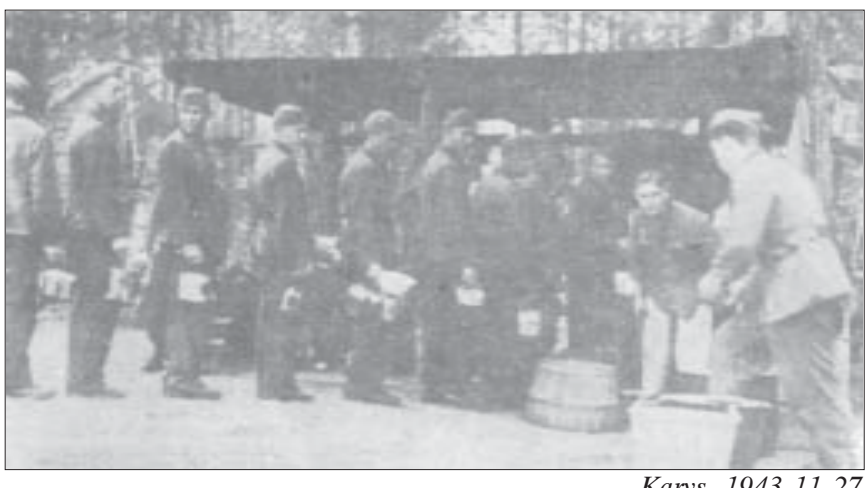

Statybos batalionų kariai prie lauko virtuvès

Karys, 19431127 
Beveik visi lietuvių statybos batalionai $1944 \mathrm{~m}$. buvo išformuoti. Istorikas P. Stankeras nenurodydamas šaltinių pateikia tokias jų išformavimo datas: 1-asis - 1944 m. birželio mèn., 2-asis - rugpjūčio mèn., 3-iasis ir 5-asis - gegužès mèn., 6-asis - spalio mèn. 4-ojo bataliono trys kuopos 1945 m. pradžioje Vakarų Prūsijoje buvo priskirtos prie vokiečių 2-osios armijos 252-osios pèstininkų divizijos ${ }^{145}$. Tačiau atrodytų, kad šios datos nèra tikslios. Iš KGB baudžiamụjų bylų ir kitų šaltinių matyti, kad 1-asis statybos batalionas išformuotas jau $1944 \mathrm{~m}$. kovo mèn., daugelis jo kariu perkelti ị vermachto 793-iaji pionieriu batalioną. Matyt, lietuviai kariai sudarẻ atskirą šio bataliono būrị. Antai A. Natkevičiaus baudžiamojoje byloje pažymèta, kad jis nuo $1944 \mathrm{~m}$. kovo iki $1945 \mathrm{~m}$. vasario mèn. buvo vokiečiu armijos 793-iojo darbo bataliono būrio vadas, vadovavo inžineriniu įtvirtinimų statybai Polocko apylinkėse, o véliau iki Vokietijos kapituliavimo - 13-ojo lietuvių savisaugos bataliono, veikusio vokiečių Kuršo grupuotės sudètyje, būrio vadas, dalyvavo kovose su Raudonaja armija ${ }^{146}$.

Koks gi buvo lietuvių statybos (inžinerijos) batalionų indèlis Vokietijos kare prieš SSRS? Pagrindinè jų veikla buvo karinių įtvirtinimų statyba, kelių tiesimas ir taisymas, tiltų statyba ir jų atstatymas, prieštankinių griovių, apkasų, tranšèjų kasimas, ịvairių fortifikacinių įrenginių, ypač bunkerių, slèptuvių, ugnies taškų, įvairiu kliūčių įrengimas ir pan. Statydami vokiečiams karinius įtvirtinimus, lietuviai kariai sunkiomis pafrontès ir geografinèmis sąlygomis dirbo ịtemptą, alinantị darbą. 5-asis statybos batalionas statydamas bunkerius dirbo po 10 val. per parą, darbui pasibaigus kareiviai dar dvi valandas buvo mokomi karybos, vèliau karinis mokymas darbo dienomis nutrauktas ir vyko tik sekmadieniais ${ }^{147}$. Pogrindinė "Nepriklausoma Lietuva" 1943 m. rudenị rašè, jog statybos batalionų darbas labai sunkus, dirbama nuo tamsos iki tamsos. Prie kiekvienos dirbančiu lietuvių karių grupès priskirtas vokiečių kareivis kaip specialistas, kuris juos prižiūri. Sanitarinẻ būklẻ bloga, jaučiama didelẻ medikamentų stoka. Anot laikraščio, būsima žiema statybos batalionų vyrus labiau gąsdino negu bolševikų artumas. Lietuviai kariai "nuplyšę, alkani, vokiečių "techniškojo" personalo keikiami ir niekad nepabaigią sunkių katorgininkų darbų vienas po kito pagaliau netenka kantrybès ir

\footnotetext{
${ }^{145}$ Stankeras P., min. veik., p. 191.

${ }^{146}$ LYA, f.K-1, ap. 58, b.42013/3, 1.428.

${ }^{147}$ Calkos A. parodymai. LVOA, f. 1, ap. 1, b. 99, 1. 87.
} 
ryžtasi bẻgti i Tẻvynę ..." ${ }^{148}$ Nepaisant propagandiniu antinacinio pogrindžio tikslų, šiuose žodžiuose, matyt, buvo nemažai tiesos. Oficialiojoje spaudoje buvo rašoma apie "pūslètas lietuvių-statybininkų rankas", kurios liudijo "juos esant gerais ir ištvermingais vyrais bet kokiame darbe", apie kas dieną ilgèjusius "mūsų vyrų" nutiestus kelius per nepereinamas Rytu pelkes, kaskart didèjusị bunkeriu ir barakų, pastatytu jų rankomis, skaičių ${ }^{149}$.

Lugos, Pskovo ir Ostrovo, Polocko, Daugpilio ir kitos apylinkès, kuriose, stabdant Raudonosios armijos puolimą, dirbo ir lietuviu statybos batalionai, tapo svarbiausiais, iš anksto įtvirtintais vokiečiu Šiaurès armijų grupès gynybiniais rajonais.

Lugos miestas buvo svarbus kelių susikirtimo mazgas, vokiečiu gynybiniai įtvirtinimai jị juose puslankiu, stipriai įtvirtintos gynybinès pozicijos èjo Sabos, Lugos ir Oredežo upès krantais. Raudonosios armijos 112-asis korpusas 1944 m. sausio 21-23 d. dẻl minètų Maloje ir Bolšoje Zamošje kaimų ir kitų vietovių įnirtingai kovesi Lugos prieigose, jos po keletą kartų ejo iš rankų i rankas. Vasario pradžioje Lugos apylinkėse vokiečiai sutelkè stiprią grupuotę: 1 tankų ir daugiau kaip 4 pèstininkų divizijų pajègas, kurios sėkmingai gynèsi. Luga išvaduota tik vasario $12 \mathrm{~d}$. pabaigoje, vokiečiu grupuoté čia nebuvo apsupta ${ }^{150}$.

Iš Lugos ir iš kitur išstumtas pagrindines savo jẻgas vokiečiai sutelkẻ Narvos bei Pskovo ir Ostrovo įtvirtintuose rajonuose. 1944 m. kovo pradžioje fronto linija èjo apytiksliai nuo Nevelio ị šiaurę Velikaja upe, per Opočką, Ostravą, Pskovą, Čudo ežero vakarine pakrante Narvos link ${ }^{151}$. Raudonosios armijos bandymai 1943 m. vasarị iškart užimti Narvą, Pskovą ir Ostrovą, iš anksto įtvirtintas gynybines pozicijas su tankiu tranšejų tinklu, su pritaikytais ilgalaikei gynybai įtvirtinimais, prieštankiniais grioviais ir minų laukais buvo nesèkmingi. Pralaužiant stiprią vokiečių gynybą, teko atlikti "planingą, kruopščiai parengtą operaciją"152. Tik 1944 m. liepos 13 d. Raudonoji armija puolè vokiečiu 16-ają ir 18-ająa armijas (Ostrovas išvaduotas liepos 21 d., Pskovas - liepos $23 \mathrm{~d}$.), vokiečiai atsitraukè į Daugpilio apylinkes.

\footnotetext{
${ }^{148}$ Statybos batalionai. Nepriklausoma Lietuva. 1943, lapkričio 15, Nr. 19-20, p. 4.

149 Augustinavičius P. Lietuvių sta/ybos/ bataliono darbai Rytuose. Karys. 1943, rugsèjo18, Nr. 38, p. 12; Savaitè, 1943, rugpjūčio 21, Nr. 33, p.520.

${ }^{150}$ Битва за Ленинград. 1941-1944. Москва, 1964, с. 373, 388-392.

${ }_{151}$ Типпельскирх К. История второй мировой войны. Москва, 1956, с. 364, 366.

${ }^{152}$ Битва за Ленинград. 1941-1944, с. 403.
} 
Irengiant visus šiuos vokiečiu gynybos įtvirtintus rajonus ir fronto linijas, dalis nuopelnu priklause ir lietuvių statybos batalionams.

Statybos batalionų kariai dirbo ne tik karinio pobūdžio darbus. Kaip matyti iš publikacijų "Karyje" ir kitoje spaudoje, 1943 m. pavasari atvykę i pafrontę Lugos apylinkẻse jie dirbo ir paprastus žemės ūkio darbus. Vietiniai gyventojai naudojosi vieno iš statybos bataliono laisvais nuo darbų arkliais įdirbti laukams. Ir patys bataliono vyrai "talkininkavo kolchozui", nes jame labai trūko darbo jègos, buvo likusios beveik vienos moterys. "Kolchozininkams", dirbusiems žemę "labai primityviai", lietuviai kariai ne tik padejjo, bet ir moke juos ūkininkauti ${ }^{153}$. Lietuvių kariu požiūris i u ūkininkavimo kultūrą rytuose išties buvo "kritiškas". $1944 \mathrm{~m}$. vasarị Panevėžyje per iškilmingą per radiją transliuotą dovanu ịteikimo lietuvių kariams, kovojusiems rytuose, ceremoniją jų atstovas 4-ojo statybos bataliono karys kalbejo: "Man teko pabuvoti įvairiose vietose Rytuose, ten, kur nesilanko turistai. Mes matėme kombainus, kuriuos kombainininkai viena ranka vairuoja, o kita šienauja. Štai tokie rusiški kombainai..." 154 (šis "antitarybinis" pareiškimas buvo išgirstas ir užfiksuotas anapus fronto linijos Lietuvos radijo laidų pasiklausymo medžiagos santraukoje).

Vienas iš problemiškesnių statybos batalionų veiklos ir gyvenimo rytuose klausimų yra jų santykiai su vietos gyventojais rusais. Apskritai galima tvirtinti, jog statybos batalionų, dažnai vadintų "darbo batalionais", veiklos pobūdis buvo "taikus", jis negadino ir nekomplikavo ju karių santykių su vietos gyventojais. Lietuviai kariai dažnai su jais kartu dirbo prie karinių įtvirtinimų, statybos ir kitų darbų. Tokius atvejus fiksavo ir sovietinių partizanų žvalgyba: "Leningrado partizanų duomenimis, kasant prieštankini griovị i šiaurès vakarus nuo Pskovo, be vietinių gyventojų, dirbo ir lietuvių darbo batalionai" ${ }^{155}$. Kitoje situacijoje negu statybos batalionai rytuose atsidūre savisaugos batalionai, iš pat pradžių kovoję su partizanais, dažnai priversti vykdyti baudžiamąsias akcijas ir prieš

\footnotetext{
${ }^{153}$ Gulmanas K. Iš N. lietuvių statybos bataliono gyvenimo Rytuose. Karys. 1943, birželio 26, Nr. 26, p. 6.

${ }^{154}$ LVOA, f. 1771 , ap. 7, b. 269, 1. 56. (Versta iš rusų kalbos)

${ }^{155}$ CPJŠ žvalgybos skyriaus viršininko plk. S. Anisimovo 1943. 11. 22 pranešimas LPJŠ žvalgybos skyriaus viršininkui B. Baranauskui. Ten pat, f. 1, ap. 1, b. 18, 1. 234; LPJŠ 1943. 1124 informacinių žinių santrauka Nr. 18. Ten pat, b. 23, 1. 22.
} 
civilius gyventojus. Kartais Lietuvoje leistoje oficialiojoje spaudoje pasirodydavo net pernelyg idiliškų, sentimentalių statybos batalionų karių gyvenimo rytuose ir santykių su vietiniais gyventojais vaizdų. Antai "Žemaičiu žemėje" $1943 \mathrm{~m}$. rudenị buvo rašoma: "pasigirdus pirmiesiems akordeono ar gitaros garsams, būdavo pamirštamas sielvartas dèl negauto iš tévynès laiško. Jei arti pasitaikydavo "kukli rusaitè", ji neišvengdavo pasiutpolkès su lietuviu kariu. Kariai turèję "nerašytą įstatymą": "per daug" pradejjęs slankioti apie rusaitès langus karys buvo "išprausiamas", tokiu būdu jam buvo primenama Agotèlè ar Elenutè, kuri likusi tėvynëje ne vieną ašarą išlieja kasdama bulves" 156 .

Aiški tokio pobūdžio rašinių agitacinè propagandinè funkcija. Ji turejjo atsverti pogrindžio spaudos visuomenès sąmonèje formuotus niūrius įvaizdžius apie statybos batalionų gyvenimą rytuose, paveikti neigiamą nusistatymą jų atžvilgiu. Tačiau įvairiuose karo metų šaltiniuose, perbėgusių pas sovietinius partizanus karių parodymuose, kuriuose apskritai netrūksta ìvairios negatyvios medžiagos apie statybos batalionus, iš esmés nėra duomenų, kompromituojančių jų karių elgesị civilių gyventojų atžvilgiu, nusikaltimus žmoniškumui ir pan. Apie gerus statybos batalionų karių santykius su vietiniais gyventojais savo atsiminimuose rašo ir Pr. Nagys: Pskovo apylinkèse 2-ojo bataliono kariai gyveno kartu su civiliais gyventojais rusais. Vèliau kaimas padalintas ị dvi dalis: vienoje pusëje gyveno civiliai, o kitoje - kareiviai. Turèję palikti savo gyvenamuosius namus rusai galëjo ateiti pasišerti gyvulių ir tvarkytis kiemuose. Paprašyti lietuviai kariai jiems ir gyvulius pašerdavo. Gyventojai, atrodo, supratę lietuvių karių padètį, skyrè juos nuo vokiečių ir kt. ${ }^{157}$

Ir vis dèlto, nors ir kokie geri buvo lietuviu karių santykiai su civiliais gyventojais rusais, statybos batalionai buvo vokiečių karinių formuočiu okupuotoje Rusijos žemėje sudedamoji dalis, jie buvo priversti paklusti vokiečiu i̊sakymams, taip pat ir tiems, kurie liesdavo civiliu gyventojų interesus. Gerai žinoma, kokią politiką vokiečiai vykdẻ rytuose ir kaip elgėsi su civiliais gyventojais, ypač vokiečiu kariuomenei traukiantis iš okupuotų Rusijos teritorijų. Kovodami su partizanais vokiečiai jų veiklos rajonuose vykdè totalinę gyventojų "evakuaciją", "išdegintos žemès"

${ }^{156}$ Lietuviškos dainos Rytuose (Iš lietuvių statybos batalionų gyvenimo). Žemaičiu žemé. 1943, spalio 23, Nr. 41, p. 2.

${ }^{157}$ Nagys Pr., min. veik., p. 68. 
taktikos akcijas. Šiaurès armijų grupès vadovybè iš gynybinių įtvirtinimų rajonų ir pafrontès sričiu vietinius gyventojus prievarta evakuavo ị vakarus, juos naudojo kaip darbo jëgą, degino gyvenamąsias vietoves, konfiskavo ir naikino turtą, kad nieko neliktu Raudonajai armijai ${ }^{158}$. Kaip tai buvo daroma Baltarusijoje ir ị kokias situacijas patekdavo lietuvių savisaugos batalionų kariai, matyti iš karo kapeliono $\mathrm{Z}$. Ignonio atsiminimų: ištisus kaimus vokiečiai sudegino, gyventojus, kurie išliko, išveže darbams i Vokietijos fabrikus. Lietuviai kariai matė pasibaisètinų vaizdų: į Danilovičiu bažnyčios šventorių suvaryti kaimo gyventojų gyvuliai ištrype kapus, išlaužè paminklus ir nubjaurojo visą šventorių. Zmonės sugrūsti i bažnyčią ir lietuvių leitenantui [J.] Abraičiui ịsakyta juos saugoti. Jis ir jo būrio vyrai griežtai protestavo. Vokiečiai tyčiojosi: "Herr Leutenant, Befehl ist Befehl (Ponas leitenante, įsakymas yra ịsakymas)"

Nėra duomenų, jog statybos batalionų kariai būtų dalyvavę vykdant masines represines akcijas prieš civilius gyventojus. Vis dèlto, kaip matyti iš statybos batalionų karių parodymų KGB, ir jiems tikriausiai teko varyti gyventojus kasti apkasų ir dirbti kitų karinio įtvirtinimo darbų ${ }^{160}$, dalyvauti prievarta evakuojant gyventojus ir jų turtą iš vietovių, kuriose buvo statomi kariniai įtvirtinimai (daug evakuotų civilių gyventojų, ypač iš Pskovo ir Polocko apylinkių, pateko ị Lietuvą), griaunant ir deginant ištuštejjusių kaimų trobesius. Statybos batalionų transporto kuopos vežè šieną, avižas, miltus ir panašų turtą iš kaimų, kurie turèjo būti sudeginti ${ }^{161}$. 1-ojo statybos batalionų karių grupé, nuteista 1949 m., kaltinta dalyvavusi tiesiant "strateginės reikšmės" kelius, deginant gyvenamąsias vietoves, suiminejjant tarybinius žmones ir išvarant juos į Vokietiją, nekalbant jau apie kovą su partizanais ${ }^{162}$.

Lietuvių statybos batalionai nedalyvavo mūšiuose su vokiečiu gynybines linijas pralaužusiais Raudonosios armijos daliniais, nepateko i

${ }^{158}$ Афанасьев. Фронт без тыла: Записки партизанского командира. Ленинград, 1983, c. $272-273$.

${ }^{159}$ Ignonis Z., min. veik., p. 205.

${ }^{160}$ Čekanausko F. 1951. 07. 26 parodymai. LVOA, f. 3377, ap. 55, b. 59, 1. 99; Ivanovo A. 1951. 05. 23 d. parodymai. Ten pat, 1. 106.

${ }^{161}$ Valkaičio K. 1951. 08. 02. parodymai. Ten pat, 1. 103; Milerio St. 1951. 08.06 parodymai. Ten pat, 1. 104.

${ }^{162}$ LYA, f.K-1, ap.58, b.42013/3, 1. 414, 417, 428 ir kt. 
jų apsuptị ir nelaisvę, nors apskritai vokiečiu pionierių ir kiti specialiosios paskirties daliniai sovietineje literatūroje yra minimi tarp Raudonosios armijos sutriuškintų vokiečių dalinių ${ }^{163}$.

Lietuvių statybos batalionams, dirbantiems prie karinių įtvirtinimų darbų, teko susidurti su nuolat aktyvinusiais savo veiklą sovietiniais partizanais. Vienoje Lugos, vẻliau Velikajos (Pskovo apylinkėse) upių pusėje vokiečių armijai buvo statomi ịtvirtinimai, kitoje buvo partizanų teritorija. Tokia "kaimynystè" lèmé 5-ojo ir kitų statybos batalionų karių kontaktus su partizanais, taip pat ir ginkluotus susidūrimus. Šiuos kontaktus taip pat veikė ir sovietinių partizanų taktika: partizanams jų vadovybė nuo 1943 m. rudens kẻlė uždavinius vokiečių užnugaryje organizuoti "gyventojų sukilimus", naikinti okupacinès valdžios įstaigas, trukdyti panaudoti gyventojus gynybinių įtvirtinimų darbams, gelbėti juos nuo sunaikinimo ir išvarymo ị Vokietiją, stiprinti kovos veiksmus vokiečių komunikacijose ir kt. ${ }^{164}$

Lietuvių statybos batalionų kovos su partizanais pobūdis ir mastas matyti iš šių faktų. Lugos apylinkèse 1-ojo bataliono kariai, tiesę kelią tarp Maloje ir Bolšoje Zamošje kaimų, ejo sargybą, saugojo juos nuo partizanų užpuolimų, rengẻ partizanams pasalas, dalyvavo vokiečių organizuotose partizanų gaudynių akcijose. Tačiau ginkluotų susidūrimų su partizanais nebuvo ${ }^{165}$.

Kaip matyti iš Pr. Nagio atsiminimų, panašaus pobūdžio buvo ir 2ojo statybos bataliono kovos veiksmai prieš partizanus. Siekiant sutrukdyti partizanams persikelti per Lugos ir Jasčeros upes, buvo patruliuojama jų paupiais, stebèti ir žvalgyti partizanų rajonai. Atvykę ị Pskovo apylinkes bataliono kariai saugojo kaimą, kuriame įsikūrè. Kaime buvo ịrengti îtvirtinimai, gynybos pozicijos. Batalionas patyre karinių susidūrimų su partizanais, kareiviai net miegodavo nenusirengę. Partizanai bataliono 1-osios kuopos kariams, vežimais gabenusiems maistą iš Pskovo, surengė pasalą, 3 kareiviai pateko ị nelaisvę, keletas buvo nukauti, batalionas kartu su vokiečiais, vlasovininkų daliniu, dalyvavo partizanų persekiojimo akcijoje, trukusioje visą dieną, keletas bataliono karių buvo sužeisti. Kita operacija prieš partizanus vykdyta 1943 m. gruodị, prieš Kalèdas, 3 dienas

\footnotetext{
163 Битва за Ленинград. 1941-1944, с. 349.

${ }^{164}$ Ten pat, c. 303-304.

165 Čekanausko F. 1951. 07. 24, Noviko Vl. 1951. 07. 24, Valkaičio K. 1951. 08. 02 parodymai. LVOA, f. 3377, ap. 55, b. 59, 1. 97, 101, 103.
} 
žvalgyta partizanų teritorija. Aktyvejant partizanų veiklai, toliau stiprinta bataliono dislokacijos vietos apsauga: trys poros "slapukų" stebejo kaimo prieigas, svarbiose vietose ịrengti trys kulkosvaidžių lizdai, kaime patruliavo kelios poros patrulių. Nepaisant to, partizanai arba jiems padẻdavę vietiniai rusai padegè bataliono kuopos raštinę ${ }^{166}$.

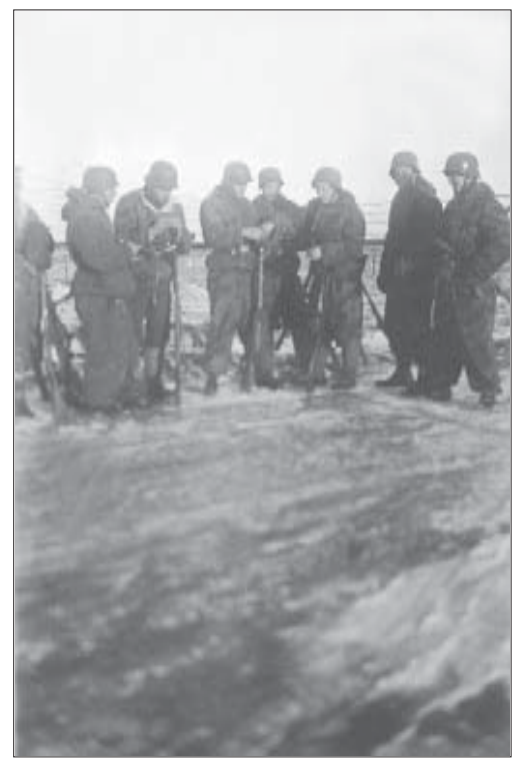

Statybos bataliono karių grupé, pasiruošusi kovai su partizanais (S. Natkevičiaus asmeninis archyvas)

KGB medžiagoje apie batalionų veiklą užfiksuota, jog Pskovo apylinkèse Kisieli kaime 1944 m. sausị lietuviu statybos batalionų kariai suèmé ir sušaudè vieną partizaną ${ }^{167}$.

Partizanai $1943 \mathrm{~m}$. rugsejjo $27 \mathrm{~d}$. mūšyje paèmè į nelaisvę tris 5-ojo statybos bataliono 1-osios kuopos karius. Vienas iš jų - biržietis Jonas Sulys smarkiai pasipriešino jị i nelaisvę paimti mèginusiems partizanams ir 3 kartus buvo sužeistas ị koją. Visi trys paimti ị nelaisvę lietuvių kariai vèliau pareiškẻ norą kovoti raudonujų partizanų gretose. J. Šulys atsišaukimu kreipèsi i Rusijos išlaisvinimo armijos (ROA) kareivius ir karininkus, ragindamas juos pereiti ì partizanų pusę ${ }^{168}$.

Oficialiojoje spaudoje, aprašant plk. A. Bironto apsilankymą lietuvių statybos batalionuose $1944 \mathrm{~m}$. pradžioje, pažymèta, jog jų kariai "ne tik gerai dirba, bet ir atkakliai kaunasi su pasitaikančiais apylinkėse partizanais. Lig šiol neturèdami nuostolių, jie apvalè savo darbo rajonus" 169

\footnotetext{
${ }^{166}$ Nagys Pr., min veik., 66-74.

${ }^{167}$ Pskovo raj. Razgovorovo kaimo gyventojo I. Kolcovo 1951. 05. 18 parodymai. LVOA, f. 3377, ap. 55, b. 59, 1. 105.

${ }^{168}$ Ten pat, f. 1771 , ap. 6, b. 127, 1. 55.

${ }^{169}$ Plk. Birontas aplankè lietuvių statybos batalionus. Ateitis. 1944, vasario 7, Nr. 31, p. 2.
} 
Vis dẻlto statybos batalionų kovos su išsiplètusiu partizaniniu karu masto ne iš tolo negalima lyginti su lietuvių savisaugos batalionų antipartizaninès kovos mastu. Kovodami su partizanais lietuviu statybos batalionai patyre nuostolių, tačiau jie nebuvo dideli. Pr. Nagys savo atsiminimuose rašo, jog 2-ojo bataliono išvykimo iš Lugos apylinkių į Pskovą išvakarẻse nuo sprogimo ugniavietėje žuvo pirmasis šio bataliono karys. Iš paskelbto nekrologo "Karyje" matyti, jog žuvęs bataliono karys - tai A. Malakauskas, kilęs iš Zarasų aps. Žandariškių kaimo. Jis mirtinai sužeistas 1943 m. rugsèjo 14 d., ugniavietėje sprogus partizanų ịkastai ir nuo užkurto laužo ịkaitusiai granatai. Nuvežtas į Lugos ligoninę lietuvių karys po keleto valandų mirè ${ }^{170}$.

Kito statybos bataliono pirmoji auka buvo kareivis marijampolietis Vl. Kuzevičius, žuvęs per susišaudymą su partizanais $1944 \mathrm{~m}$. sausio $23 \mathrm{~d}{ }^{171}$

1944 m. sausio 24 d. P(skovo?) karo ligoninejje mire prieš keletą dienų partizanų mirtinai sužeistas statybos batalionų karys biržietis K. Gatavyna ${ }^{172}$.

1943 m. gruodžio 1 d. Marijampolès apylinkèse nušautas grižęes atostogu statybos bataliono karys St. Samušis (ji nušove besislapstantis ROA dezertyras) $)^{173}$.

Nors apibendrinamojo pobūdžio duomenų apie žuvusius statybos batalionų karius nèra, galima daryti išvadą, jog žuvo tik pavieniai kariai. Be abejo, daugiau buvo sužeistų, paskui tapusių invalidais statybos batalionų karių. Antai Šiaulių karo ligonineje 1/615 (buvusiose Gubernijos kareivinėse) 1943 m. gruodžio viduryje gydèsi 7 lietuviai kariai: 2 - iš savisaugos, 3 - iš statybos batalionų, 2 - iš vokiečių dalinių ${ }^{174}$.

Rytuose su partizanais ir fronte kovojusių lietuvių savisaugos batalionų nuostoliai - žuvusių ir sužeistų - buvo nepalyginamai didesni. Nors šie nuostoliai taip pat nėra tikslūs, galima manyti, kad iki 1944 m. vasaros žuvo apie 500 savisaugos batalionų karių.

Statybos batalionų patirti nežymūs nuostoliai kariaujant masinị pobūdị igavusį partizaninį karą ir visa kita jų veikla rytuose rodo, jog pirmiausia jie buvo "dirbančios", o ne kovojančios su priešu karinès formuotés.

\footnotetext{
${ }^{170}$ Nagys Pr. Min. veik., p. 67; Morkūnas Ign. A. a. Antanas Malakauskas. Karys. 1943, spalio 9, Nr. 41, p. 4.

${ }^{171}$ Gulmanas A. A. a. eil. Vl. Kuzevičius. Ten pat. 1944, balandžio 1, Nr. 13, p. 5.

${ }^{172}$ Kuopos vado ir karių užuojauta. Ten pat. 1944, vasario 19, Nr. 7, p. 3.

173 A. a. eil. Stasys Samušis. Ten pat. 1944, balandžio 8, Nr. 1, p. 7.

${ }^{174}$ Informacija: valandèlè pas sužeistus lietuvių karius. Tẻviškẻ (Šiauliai). 1943, gruodžio 24, Nr. 48, p. 6.
} 
Kai kurie jų atlikti darbai (pvz., kelių tiesimas ir taisymas, griovių kasimas sausinant pelkes ir miškus) turëjo ne tik karinę, bet ir civilinę, pozityvią reikšmę. Lietuvos administracija, oficialioji spauda "totalinès mobilizacijos" ir propagandinès kovos su bolševizmu sąlygomis kẻe i i rytus išsiųstų savisaugos, statybos batalionų, vadinamujų "karo transportininkų", kituose vermachto daliniuose tarnavusių lietuvių karių ir jų šeimų materialinès, socialinės, kultūrinės globos klausimus. Spauda, remdamasi Lietuvos kariuomenès ir visuomenès bendradarbiavimo pavyzdžiais, nuolat pasigesdavo "tvirtų", nuolatiniu visuomenès ryšių su lietuviais kariais rytuose. Šiais dalykais rūpintis 1943 m. rudenị prie Vidaus reikalų vadybos, Visuomenès reikalų departamento Kaune ịsteigtas Karių ir jų šeimų globos vyriausiasis komitetas, Vilniuje, Šiauliuose ir Panevėžyje veikè jo skyriai, apskrityse ir valsčiuose - globos komitetai. Jie rūpinosi sužeistais lietuviais kariais, organizavo ịvairių daiktų rinkimo akcijas, meno kolektyvų išvykas ị lietuviškus dalinius, jų aprūpinimą knygomis, periodine spauda, radijo aparatais, muzikos plokštelėmis, sporto įrankiais ir kt. Kiekviena Lietuvos apskritis globojo savisaugos ar statybos batalioną: 2-aji statybos batalioną globojo Alytaus aps., 4-aji - Panevėžio aps. ir kt. 1944 m. pradžioje Panevéžio aps. buvo 340 lietuvių karių šeimų, visuose 16 apskrities valsčių veikẻ Karių ir jų šeimų globos komitetai, 1944 m. vasario mèn. jie lietuvių kariu atstovams įteike $4250 \mathrm{rm}, 700$ porų kojinių, daugiau kaip 1000 porų pirštinių, 150 rankšluosčių ${ }^{175}$.

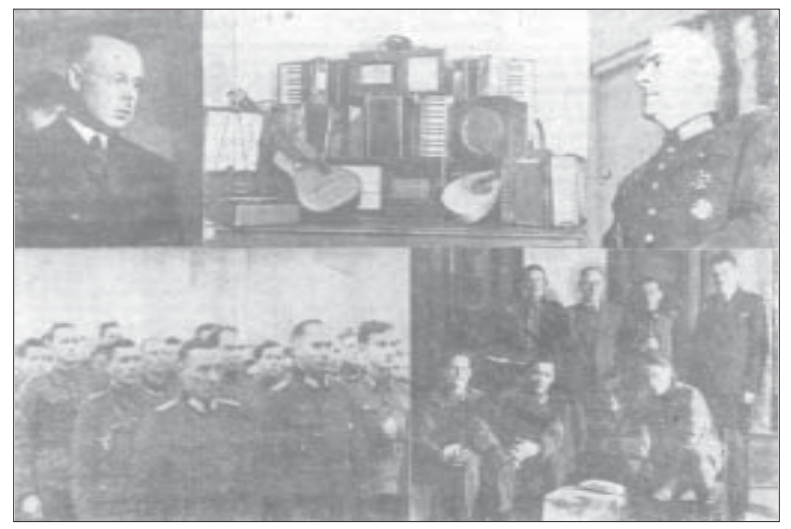

Nuotraukų montažas "Karyje" (1943 12 18): iškilmingai įteikiamos dovanos lietuvių savisaugos ir statybos batalionų atstovams: viršuje dešinèje gen. E. Justas, kairëje P. Kubiliūnas, viduryje vertingesnès dovanos. Apačioje - karių ir jų šeimu globos komitetu atstovai

${ }^{175}$ Lietuvos radijo paklausymo medžiagos santrauka, 1944. 02. 18 LVOA, f. 1771, ap. 7, b. 269, 1. 56. 
1943 m. pabaigoje Kaune pradètas leisti visu pirma statybos batalionų kariams skirtas laikraštis "Tẻvynè ir frontas" (red. Br. Daunoras), turejęs palaikyti glaudesnị ryšị tarp Lietuvos visuomenès ir lietuvių karių. Pirmajame laikraščio numeryje buvo spausdinami P. Kubiliūno, St. Raštikio, gen. tarejo A. Ramanausko straipsniai ${ }^{176}$.

Nepaisant to, jog komitetų veikla objektyviai tarnavo Vokietijos propagandiniams ir kariniams interesams, socialinè, kultūrinè, moralinè lietuvių karių globa turëjo humanitarinị pobūdį, praskaidrino nelengvą jų dalią rytuose. Neabejotina, jog dèl šios globos statybos batalionų karius pasiekdavo ir antinacinio pogrindžio spauda, formavusi jų antivokiškas, patriotines nuotaikas ir daugeli kitu procesų. Statybos batalionų kariai reagavo ir ị ịvykius Lietuvoje. 2-ojo bataliono vadas A. Milaševičius $1943 \mathrm{~m}$. lapkritị nusiuntė gen. P. Kubiliūnui pareiškimą, pritariantị Lietuvoje vykusiems antisovietiniams mitingams, organizuotiems pasmerkti per Spalio revoliucijos metines Maskvoje pasakytą Stalino kalbą, kurioje buvo užsiminta apie greitą Pabaltijo tautụ "išvadavimą"177 ir kt.

\section{Lietuvių statybos batalionų karių likimai}

Lietuvos vyrų, tarnavusių statybos (inžinerijos) batalionuose, likimai buvo labai ịvairūs, daug ịvairesni negu tarnavusiųjų kitose vokiškos kilmės lietuviškosiose formuotèse, tačiau dažniausiai tokie pat skaudūs ir tragiški.

Vokiečiu okupacijos metais iš statybos batalionų dezertyravusiems ir besislapsčiusiems Lietuvoje kariams grèsé pavojus patekti ị kalëjimus, karo belaisvių stovyklas, kur jụ laukẻ badas ir alinantis darbas, išsiuntimas darbams i Vokietiją. $1943 \mathrm{~m}$. liepos mèn. sovietinių karo belaisvių stovyklai Vilniuje buvo perduoti 98 kaliniai - "mobilizacijų sabotuotojai", tarp jų 14 vyrų, pabėgusių iš vermachto ir statybos batalionų: B. Benderis - iš 1-ojo, Kl. Rimšelis, A. Babarskas - iš 3-iojo, J. Mikelevičius, P. Jakseboga - iš 5-ojo ir kt. ${ }^{178}$

Vis dèlto galima manyti, kad daugelis bègusių iš statybos batalionų vyrų vokiečių okupacijos metais sẻkmingai prasislapstẻ ir išvengẻ vokie-

\footnotetext{
${ }^{176}$ Išèjo lietuvių statybos bataliono laikraštis. Žemaičiu žemé. 1943, gruodžio 24, Nr. 49, p. 1; LPJŠ 1943. 12. 28 informacinių žinių santrauka. $L V O A$, f. 1, ap. 1, b. 23, 1. 6.

${ }^{177}$ Lietuvos radijo paklausymo medžiagos santrauka, 1943. 11. 27-12. 08 LVOA, f. 1771, ap. 6, b. $171,1.98$.

${ }^{178}$ Rukšènas K., min. veik., p. 68.
} 
čių represijų ir, matyt, net neịsivaizdavo, koks likimas ir represijos jų laukè atejus sovietiniams okupantams.

Kokie buvo lietuvių karių likimai išformavus statybos batalionus, karo ir pirmaisiais pokario metais? Apibendrinamojo pobūdžio duomenu nėra, sprendžiant iš atskirų faktų galima daryti išvadą, jog daug pateko ị vokiečių statybos (inžinerijos) dalinius, o Vokietijai kapituliavus - ị Raudonosios armijos nelaisvę. Jie atsidūrẻ vokiečių karo belaisvių stovyklose, specialiuosiuose NKVD lageriuose - patikrinimo ir filtravimo stovyklose, buvo tikrinami specialiujuc komisijų, sudarytų iš NKVD, saugumo ir armijos dalinių kontržvalgybos "Smerš" atstovų.

Daugelis buvusių statybos batalionų karių, sėkmingai prasislapsčiusių ir sulaukusių sovietinio "išvadavimo", $1944 \mathrm{~m}$. buvo mobilizuoti i Raudonają armiją, pateko ị jos atsargos ar darbo batalionus, ištarnavo 2-3 ir daugiau metų, buvo apdovanoti medaliais "Už pergalę prieš Vokietiją" ir kitais sovietiniais kariniais apdovanojimais ${ }^{179}$.

Išformuojant statybos batalionus, kai kurie jų kariai pateko į savisaugos batalionus, i juose buvusias statybos kuopas ${ }^{180}$. Statybos batalionų kariai verbuoti ị ịvairias vokiečių diversines grupes, ruošti darbui sovietiniame užnugaryje ${ }^{181}$.

Nemažai statybos batalionų karių ịstojo ị 1944 m. kurtas lietuviškas karines formuotes - Lietuvos vietinę rinktinę, Tẻvynès apsaugos rinktinę, paskui liko Lietuvoje, slapstėsi, tapo ginkluotos antisovietinès rezistencijos dalyviais.

Iš visų statybos batalionų karių žymiausiu veikëju tapo 2-ojo statybos bataliono vadas majoras A. Milaševičius. 1944 m. jis su šeima traukèsi i Vakarus, pateko ị Drezdeno bombardavimą, čia žuvo jo šeima. Likęs vienas grịžo ị Lietuvą, ịsitrauke i ginkluoto pasipriešinimo kovą, vadovavo Lietuvos partizanų Jūros sričiai, buvo aktyvios ginkluotos kovos šalininkas. Žuvo 1950 m. rugsėjo 9 d. Tauragès aps. Kaltinėnų vls. Koroblių k. ${ }^{182}$

\footnotetext{
${ }^{179}$ Noviko Vl. 1951. 07. 24 parodymai. Ten pat, f. 3377, ap. 55, b. 59, 1. 102; Malinausko L. ir kt. baudžiamoji byla, $L Y A$, f. K-1, ap. 58, b. 42013/3, 1. 416.

${ }^{180} L C V A$, f. R-669, ap. 1, b. 1, 1. 4.

${ }^{181}$ Milijieno Vl. 1949 m. parodymai. LVOA, f. 3377, ap. 55, b. 185, 1. 82-85.

${ }^{182}$ Gaškaitė-Žemaitienė N. Žuvusiuju prezidentas: Jono Žemaičio biografija. Vilnius, 1998, p.145,163, 197.
} 
Dalis buvusių statybos batalionų kariu ịvairiais būdais pateko į Vakarus. Statybos bataliono vyr. Itn. V. Perminas $1945 \mathrm{~m}$. gegužès mènesį su 150 vyrų daliniu prie Liubeko miesto pasidavè anglams ${ }^{183}$. (Matyt, šis dalinys priklausė 4-ajam statybos batalionui, kurio 3 kuopos Vakarų Prūsijoje buvo priskirtos vokiečiu 252-ajai pėstininkų divizijai.)

1-ojo statybos bataliono vadas K. Pranckonis $1944 \mathrm{~m}$. vasarą ir rudenị dalyvavo Žemaitijoje formuojant Tèvynès apsaugos rinktinę (TAR), pasitraukè i Vakarus, $1957 \mathrm{~m}$. apsigyveno JAV. Jo sūnus A. Pranckonis liko Lietuvoje, 1949 m. kartu su kitais 1-ojo bataliono kariais nuteistas 10 metu pataisos darbų kalëjimo.

Statybos batalionų kariai, Leningrado srityje perèję pas sovietinius partizanus ar patekę i nelaisvę bei kovoję jų gretose sritị išvadavus ir išformavus partizanų brigadas, iš surinkimo ir patikrinimo punktų 1944 m. balandžio mèn. išsiųsti ị Balachną (Gorkio sr.), ị Raudonosios armijos 16-osios lietuviškosios šaulių divizijos 2-aji atsargos batalioną: i ji i iš Leningrado išsiųsta daugiau kaip 30 lietuvių, tarp jų 13 buvusiu statybos batalionų ir vokiečių priešlèktuvinès gynybos daliniu karių ${ }^{184}$.

I lietuvių statybos batalionų karius, tapusius sovietiniais partizanais, sovietiné valdžia žiūrèjo su nepasitikejjimu. Nepaisant to, kad išaiškinti partizanus ir pristatyti juos valstybiniams apdovanojimams buvo "ypatingos politinès reikšmės" dalykas, LKP(b) CK sekretorius A. Sniečkus 1946 m. pradžioje nurodè "jokiu būdu nepristatinèti asmenų, tarnavusių vokiečiu armijoje, įvairiuose statybos batalionuose, vlasovininkų arba asmenų, davusių raštišką sutikimą bendradarbiauti su gestapu arba policija"185.

Kaip toliau klostėsi likimai lietuvių karių, tarnavusių Vokietijos karinèse ir policinèse formuotėse? Karo belaisvių stovyklose 1945 m. pabaigoje pradètas lietuvių, latvių ir estụ tautybès belaisvių nuolatinių Pabaltijo gyventojų nustatymo darbas. Jie, taip pat buvusių vokiečių karinių ir policinių formuočių lietuvių, latvių ir estų tautybių kariai, išaiškinti tarp sugrąžintų iš Vokietijos pabègèlių ar likę Lietuvoje, Latvijoje ir

\footnotetext{
${ }^{183}$ Baltušis L. Neužmirškime garbingų vyrų. Kardas. 1999, Nr. 1-2, p. 31.

${ }^{184}$ Oginto A., Bražuko A. 1944 m. parodymai. LVOA, f. 1, ap. 1, b. 100, 1. 6, 17-18.

${ }^{185}$ LKP(b) CK sekretoriaus A. Sniečkaus 1945. 01. 02 raštas LKP(b) apskričių (miestų) sekretoriams. Ten pat, f. 3113 , ap. $3113-5$, b. $44,1.1$.
} 
Estijoje, buvo priskirti vadinamajai "vlasovininkų" kategorijai ir 6-iems metams turèjo būti ištremti darbams ị tolimus SSRS rajonus. Tačiau, daugiausia Latvijos SSR partinès ir sovietų valdžios pastangomis, motyvuojant, jog Latvijos gyventojai atsidūrẻ Vokietijos armijoje vykdant prievartines mobilizacijas, latviams, taip pat estams ir lietuviams, nebuvo taikoma "vlasovininkams" numatyta tremtis, jie buvo paleisti namo.

Taigi buvę statybos batalionų kariai pirmaisiais pokario metais nepakliuvo ị KBG akiratị, nebuvo persekiojami, kalinami ar kitaip baudžiami. Sovietinis režimas ir jo represinis aparatas pirmiausia buvo užsièmęs, jo požiūriu, daug pavojingesniais politiniais priešais, labiau "nusipelniusiais" vokiečių pagalbininkais negu statybos arba darbo batalionų kariai. Kai kurie buvę statybos batalionų kariai, nuslëpę faktus apie tarnybą statybos batalionuose, įstojo ị komunistų partiją, net sugebejjo užimti atsakingas vadovaujančias pareigas. Antai buvęs statybos batalionų karys Pr. Stabingis tapo Lazdijų aps. prokuroru, jau minètas B. Petrauskas - Aštriosios Kirsnos (Lazdijų aps.) mokyklos direktoriumi. Demaskuoti buvę statybos batalionų kariai $1947 \mathrm{~m}$. pašalinti iš kandidatų į komunistų partijos narius ir atleisti iš užimamų pareigų ${ }^{186}$. İdomu pažymèti, kad komunistų dokumentuose statybos batalionų kariai kaltinti dirbę "stiprinant vokiečiu gynybines linijas", apie jų kovą su sovietiniais partizanais ar "nusikalstamus" veiksmus prieš civilius gyventojus neužsimenama.

Kaip matyti iš KGB archyvų šaltinių, statybos batalionų kariai i sovietinių represinių tarnybų akirati pateko 5-ojo dešimtmečio pabaigoje-6-ojo dešimtmečio pradžioje: Lietuvoje išaiškinti kariai pradėti suiminèti, tardyti, jiems pradètos baudžiamosios bylos, ieškota kompromituojančių, demaskuojančių jų veiklą faktų, rinkti liudytojų parodymai batalionų veiklos vietose Rusijoje ir kt.

1949 m. liepos-rugsėjo mèn. suimti buvusio 1-ojo lietuvių statybos bataliono kariai A. Natkevičius, J. Šalna, L. Boreika, Ign. Bukšnaitis, Ad. Navickas, L. Malinauskas, V. M. Mulevičius ir A. Pranckevičius. Šie ir kiti buvę statybos batalionų kariai suimti "už tarnybą vokiečių armijoje”, ši tarnyba kvalifikuota kaip "sunkus nusikaltimas”. Ypatingojo pasi-

${ }^{186}$ LKP(b) CK biuro 1947. 11. 19 nutarimas dẻ LKP(b) Lazdijų apskrities komiteto nutarimo apie Pr. Stabingio ir $\mathrm{B}$. Petrausko pašalinimą iš kandidatų i $\mathrm{VKP}(\mathrm{b})$ narius. $L V O A$, f. 1771, ap. 10, b. 204, 1. 2, 59.

304 
tarimo prie SSRS MGB 1949 m. gruodžio 17 d. sprendimu, vadovaujantis Rusijos federacijos baudžiamojo kodekso 58-I straipsniu (Tèvynès išdavimas), visi minèti 1-ojo statybos bataliono kariai nuteisti po $25 \mathrm{~m}$. pataisos darbų kalejjimo, išskyrus V. Mulevičių ir A. Pranckevičių, nuteistus po $10 \mathrm{~m}$. kalejjimo (1955 m. L.Boreikai ir L. Malinauskui bausmé sumažinta iki $10 \mathrm{~m}$. pataisos darbų kalejjimo) $)^{187}$.

Taigi KGB ir visa sovietinè represinė mašina rūsčiai baude buvusius statybos batalionų karius, nepaisant to, kad nebuvo pakankamai medžiagos įrodyti jų įvykdytų "nusikaltimų” sudéčiai, kad KGB pripažino priverstines daugelio statybos batalionų karių patekimo ị juos aplinkybes. Iš esmès sovietinės bausmės statybos batalionų kariams (išskyrus kraštutinius atvejus - bausmes už dalyvavimą masinėse žydų žudynèse) niekuo nesiskyrė nuo bausmių savisaugos batalionų kariams, kurių tikri ir tariami nusikaltimai žmoniškumui ir "sovietinei Tẻvynei” buvo nepalyginamai didesni.

Patys nuteisti statybos batalionų kariai, jų giminès ir artimieji SSRS Aukščiausiosios Tarybos prezidiumui, SSRS Generaliniam prokurorui rašè raštus, kuriuose buvo prašoma sumažinti bausmes arba kreipiamasi dèl reabilitacijos. Nors bausmès ir buvo mažinamos, prašymai dèl reabilitavimo buvo atmesti.

Buvęs 1-ojo lietuvių statybos bataliono karininkas Antanas Natkevičius, $1956 \mathrm{~m}$. paleistas iš Intos lagerio, dirbo šachtos inžinieriumi elektriku, atostogų metu atvažiuodavo ị Lietuvą. Neaiškiomis aplinkybèmis miré Intoje 1965 m. vasarą, išlydèjęs šeimą ị Lietuvą. A. Natkevičiaus palaikai 1990 m. parvežti ị Lietuvą ir palaidoti Vilniuje ${ }^{188}$.

Apibendrinant pateiktą gausią ir prieštaringą medžiagą, galima daryti išvadą, kad lietuvių statybos (inžinerijos) batalionų istorija - tai Lietuvos karių, lietuviškų karinių formuočių, kartu ir visos lietuvių tautos prieštaringos ir skaudžios istorijos sudedamoji dalis. Daugelis statybos batalionų istorijos ir su ja susijusių klausimų dar neatskleisti ir turi būti tolesnių tyrinėjimų ir apmąstymų objektas. Lietuvių statybos batalionams kaip karinei formuotei buvo lemta tapti nesėkmingai bandyto suformuoti SS lietuvių legiono savotišku toli gražu jam nelygiaverčiu pakaitalu,

187 Žr. LYA, f. K-1, ap. 58, b. 42013/3, 1. 414, 432-433.

${ }^{188} \mathrm{~S}$. Natkevičiaus liudijimas. 
kartu ir nuolaida nacių okupantams, siekusiems savo interesais "totališkai” ịtraukti Lietuvą ị karą. Lietuvių tautos interesų požiūriu lietuvių statybos dalinių sukūrimą ir jų veiklą vermachto sudètyje galima vertinti kaip minimalų, neišvengiamo karinio bendradarbiavimo su okupantu rezultatą, kuris leido laviruoti, gintis nuo masinių represijų, išsaugoti jaunimą nuo žūties fronte, kartu išsaugant nors ir menką Lietuvos ginkluotụjų pajègų atkūrimo, susiklosčius palankioms aplinkybẻms, galimybę. Šios idèjos realizavimo požiūriu statybos batalionai kaip karinė formuotė buvo savotiškas tiltas tarp SS lietuvių legiono ir 1944 m. nesėkmingai bandytos formuoti Lietuvos vietinès rinktinès, puoselėjant viltis, deja, neišsipildžiusias, jog ji taps atkurtos Lietuvos kariuomenés branduoliu.

\section{Reziumè}

1943 m. pavasarị nacių Vokietijos okupuotos Lietuvos visuomenei pasipriešinus SS lietuvių legiono steigimui, nacių okupantai atsisakė planų kurti SS kariuomenès dalinius, oficialiai deklaravo ir stengési realizuoti nuostatą imti Lietuvos vyrus tik darbams kariuomeneje ir Vokietijos reiche. Iškart po SS legiono boikoto svarbiausias okupantų siekis buvo lietuvių statybos (inžinerijos) (Litauische Bauabteilung) batalionus formuoti vermachto sudètyje darbams pafrontėje. Nors Lietuvos visuomenès, net ir antinacinio pogrindžio nusistatymas okupantų mobilizacinių pastangų atžvilgiu po SS legiono boikoto nebuvo visiškai vienodas, jos susilaukè aktyvaus pasipriešinimo: vokiečiams ir lietuvių "savivaldai" iškilo dideliu problemų iš beveik 100 tūkst. Lietuvos vyrų rezervo suformuoti kelių tūkstančių žmonių statybos dalinius. Jie formuoti daugiausia priverstinėmis ar pusiau priverstinėmis priemonėmis. $1943 \mathrm{~m}$. balandžio-rugpjūčio mènesiais suformuoti ir pasiųsti ị vokiečių Šiaurès fronto armijų užnugarị 5 lietuvių statybos batalionai, juose buvo apie 2,5-3 tūkst. Lietuvos vyrų. Svarbiausia šių batalionų karinès veiklos sritis - karinių įtvirtinimų statyba, gynybinių rajonų ir fronto linijų besitraukiančiai vokiečių armijai ịtvirtinimo darbai (prieštankinių griovių, apkasų kasimas, kelių tiesimas, įvairių fortifikaciniụ ịrenginių, bunkerių, slèptuviụ, ugnies taškų, kliūčiu ir pan. įrengimas). Lietuvių statybos batalionai dirbo Lugos, Narvos, Pskovo, Polocko, Breslavlio, Daugpilio apylinkėse. Savo darbo rajonuose lietuvių kariai $1944 \mathrm{~m}$. susidūrè su išplètusiais veiklą sovietiniais partizanais, dalyvavo antipartizaniškose akcijose (partizanų rajonų žvalgyba, miš- 
kų valymas, partizanų persekiojimas). Lietuvių statybos batalionų kariai nedalyvavo represinèse baudžiamosiose akcijose prieš civilius gyventojus. Batalionuose vyravo antivokiškos nuotaikos (nemažai jų karių dezertyravo ị Lietuvą). Statybos batalionų karių buvo ir sovietinių partizanų būriuose. Visi lietuvių statybos batalionai $1944 \mathrm{~m}$. išformuoti, jų kariai pateko ị vokiečiu statybos dalinius, ịvairias lietuviškas karines formuotes. Nuo 1943 m. vidurio Lietuvos gyventojai daugiausia imti tik darbams Vokietijos karo pramonėje. 